\title{
Structural inversion in the northern South China Sea continental margin and its tectonic implications
}

\author{
Chin-Da Huang ${ }^{1,3}$, Tung-Yi Lee ${ }^{1, *}$, Ching-Hua Lo ${ }^{2}$, Sun-Lin Chung ${ }^{2}$, Jong-Chang Wu ${ }^{3}$, \\ Ching-Lung Tien ${ }^{3}$, Meng-Wan $\mathrm{Yeh}^{4}$, Shiu-Chi Chen ${ }^{3}$, Yu-Lu Chan ${ }^{1}$, and Ching-Yi Hu ${ }^{2,3}$ \\ ${ }^{1}$ Department of Earth Sciences, National Taiwan Normal University, Taipei, Taiwan \\ ${ }^{2}$ Department of Geosciences, National Taiwan University, Taipei, Taiwan \\ ${ }^{3}$ Exploration and Production Business Division, Chinese Petroleum Corporation, Taipei, Taiwan \\ ${ }^{4}$ Center for General Education, National Taiwan Normal University, Taipei, Taiwan
}

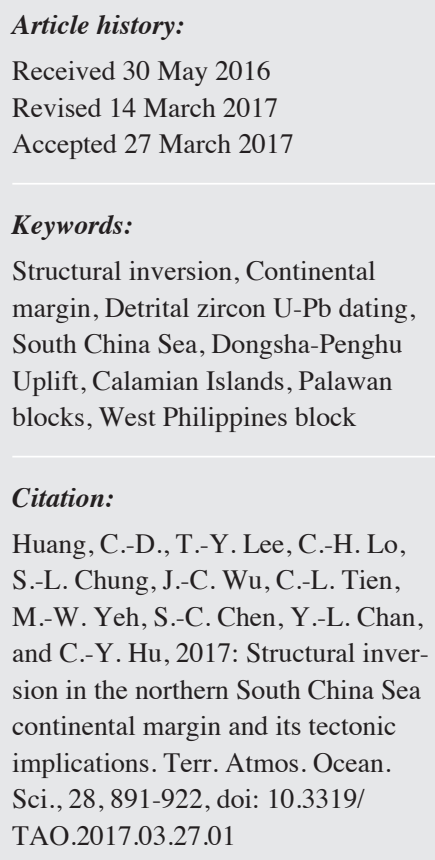

Received 30 May 2016

Revised 14 March 2017

Accepted 27 March 2017

Keywords:

Structural inversion, Continental margin, Detrital zircon U-Pb dating, South China Sea, Dongsha-Penghu Uplift, Calamian Islands, Palawan blocks, West Philippines block

Citation:

Huang, C.-D., T.-Y. Lee, C.-H. Lo, S.-L. Chung, J.-C. Wu, C.-L. Tien, M.-W. Yeh, S.-C. Chen, Y.-L. Chan, and C.-Y. Hu, 2017: Structural inversion in the northern South China Sea continental margin and its tectonic implications. Terr. Atmos. Ocean. Sci., 28, 891-922, doi: 10.3319/

TAO.2017.03.27.01

\begin{abstract}
The northern South China Sea (SCS) continental margin was proposed to be an active margin during the Mesozoic. However, only a few papers discussed the Mesozoic structural evolution in this region. Here, we provide information based on the seismic profile interpretations with age control from biostratigraphic studies and detrital zircon U-Pb dates of well MZ-1-1 in the western Dongsha-Penghu Uplift of the northern SCS continental margin. The industrial seismic profiles reveal evidence for structural inversion as represented by folds and high-angle reverse faults, formed by reactivation of pre-existing normal faults. The inversion event likely started after the Early Cretaceous, and developed in Late Cretaceous, but ceased before the Cenozoic. The areal extent of the structural inversion was restricted in the western Dongsha-Penghu Uplift and was approximately $100 \mathrm{~km}$ in width. Based on the paleogeographic reconstruction of SCS, the structural inversion was likely formed by a collision between the seamount (volcanic islands) swarm of the current North Palawan block (mainly the Calamian Islands) and the northern SCS continental margin around Late Cretaceous.
\end{abstract}

\section{INTRODUCTION}

The Mesozoic evolution of the South China Sea (SCS) continental margin, according to different models, e.g., Taylor and Hayes (1980), Holloway (1982), Faure et al. (1989), $\mathrm{Li}$ and $\mathrm{Li}$ (2007), and $\mathrm{Li}$ et al. (2012) can be summarized as that the current northern continental margin of the SCS experienced at least two tectonic regimes since the Late Mesozoic: (1) the initial regime was an active margin characterized by the development of continental arcs between 280 and $90 \mathrm{Ma}$; and (2) after $90 \mathrm{Ma}$ the active subduction ceased and a passive margin developed along with a series of marginal basins.

\footnotetext{
* Corresponding author

E-mail:t44001@ntnu.edu.tw
}

During the active margin regime, a Mesozoic subduction zone existed along the northern continental margin of the SCS (Holloway 1982). In contrast, the passive continental margin regime experienced rifting and seafloor-spreading from the Oligocene to the Middle Miocene, and a small ocean basin was formed in the Cenozoic (Taylor and Hayes 1980, 1983; Briais et al. 1993). Thus, the mechanism for the transition to a Cenozoic extensional setting is unclear because of complex Cenozoic tectonic events such as opening of the SCS had completely transformed the Mesozoic configuration (Taylor and Hayes 1980, 1983; Holloway 1982; $\mathrm{Li}$ and $\mathrm{Li}$ 2007; $\mathrm{Li}$ et al. 2012). Detailed studies of the Mesozoic to Cenozoic tectonics in the northern SCS continental margin have been hampered by the rarity or unavailability of subsurface information. Generally, the collision events 
should have induced contractional features that are likely to have been preserved in the Mesozoic strata in the northern SCS margins. Here we compiled four regional geological profiles perpendicular to the northern continental margin of the SCS (Figs. 1 and 2; see Fig. 1 for the locations of profiles), showing that such Mesozoic contractional structures do not appear in the four long regional geological profiles. The four profiles have similar structural styles for the distribution of grabens and hosts that resulted from rifting and
Cenozoic SCS seafloor spreading. Only the middle portion of the B-B' profile (close to the western Dongsha-Penghu Uplift) shows different characteristics with a contractional structure in the Mesozoic formation. This is critical to the tectonics of this region but has not been discussed until the drilling of well MZ-1-1 (Yan and Liu 2004; Shi and Li 2012; Yan et al. 2014). Therefore, in this study, we have focused on the western Dongsha-Penghu Uplift area and tried to decipher the Mesozoic tectonic history of the northern

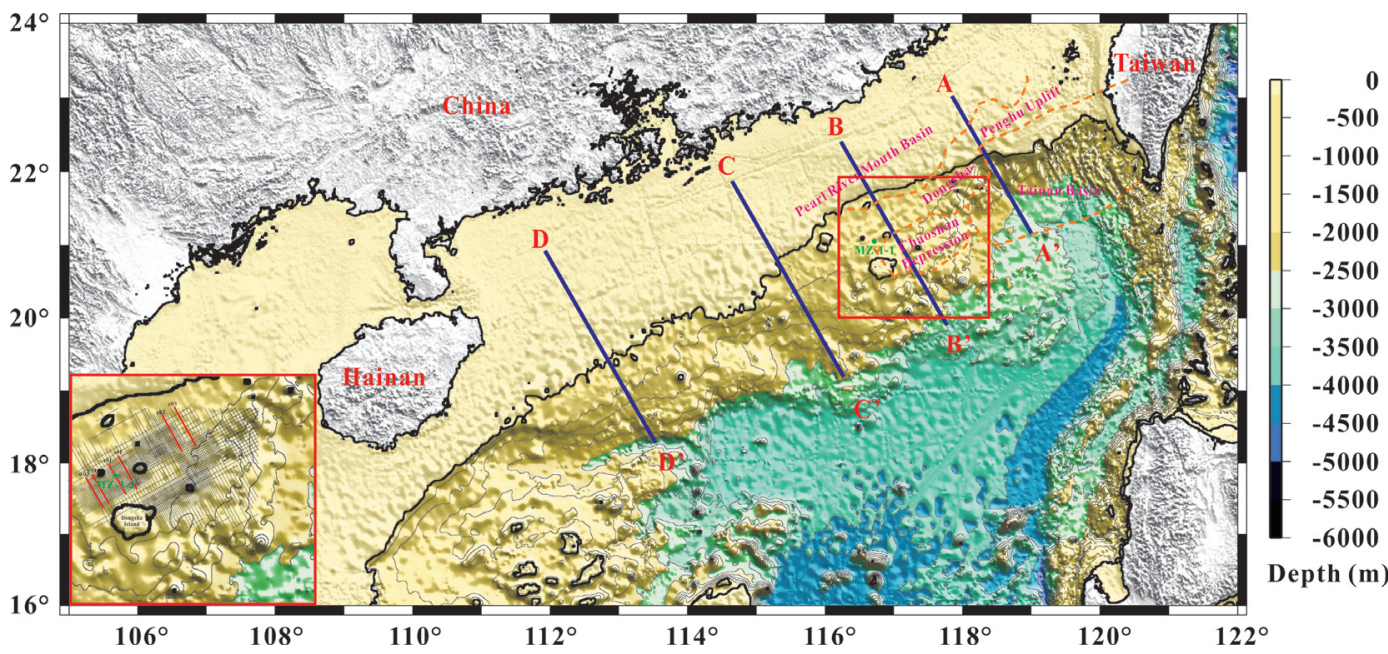

Fig. 1. Regional topographic map of the northern South China Sea. The four blue lines (A-A' to D-D') are long geological profiles across the northern continental margin of the SCS compiled from Ru and Pigott (1986), Clift and Lin (2001), Shi et al. (2005), and Zhou et al. (2008). The four profiles are shown in Fig. 2. The red square shows the location of the multi-channel seismic profiles (black lines), well MZ-1-1 (green circle and label), seismic profiles used in Figs. 4 and 7 (red lines) zoom in lower left. (Color online only)

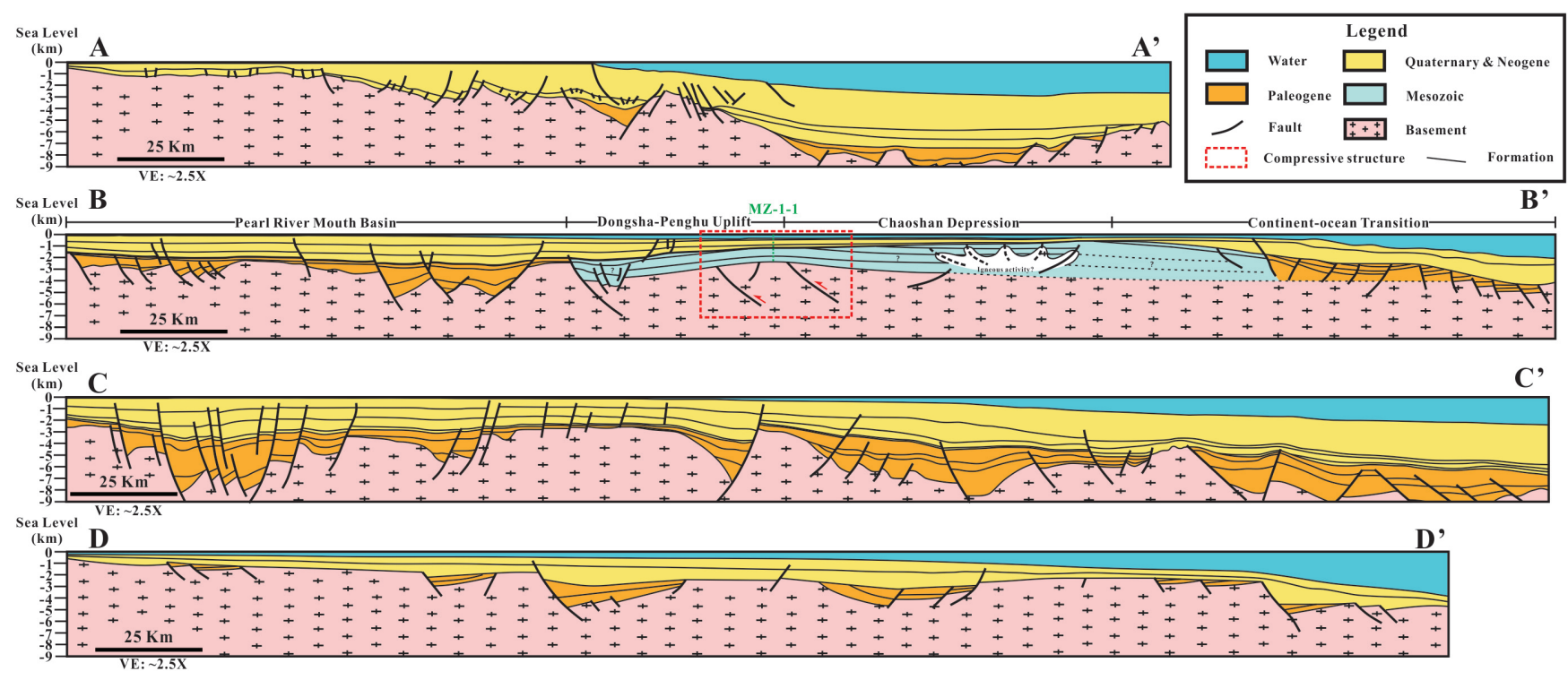

Fig. 2. Comparison of four long profiles across the northern continental margin of the SCS. The four long profiles from A-A' to D-D' across the northern continental margin of the SCS from NE to SW are compiling from Ru and Pigott (1986), Clift and Lin (2001), Shi et al. (2005), Zhou et al. (2008), and seismic profiles in this study. See Fig. 1 for locations of the profiles. Note that the igneous event of B-B' make it difficult to interpret the continuous strata but still shows the different tectonic events (such as contractional structures, i.e., high-angle reverse faults, from the other three profiles). The well MZ-1-1 (green dash line and label) is located around the high-angle reverse faults of B-B'. (Color online only) 
SCS continental margin.

This study uses new industrial seismic data, detrital zircon U-Pb geochronology and the MZ-1-1 drilling results to discuss the depositional history and tectonic evolution of the northern SCS continental margin during the Mesozoic. We used the data to determine the possible cause for the tectonic inversion in the Dongsha-Penghu Uplift. In doing so, we hope to offer a better interpretation of the tectonic evolution in the northern SCS continental margin and also to provide better constraints for future hydrocarbon exploration in the deep-water area.

\section{STUDY AREA AND REGIONAL GEOLOGY}

A brief overview of the complex geological history, according to previous studies (Hilde et al. 1977; Holloway 1982; Taylor and Hayes 1983; Zheng 1985; Letouzey and Sage 1988; Williams et al. 1988; Lüdmann and Wong 1999; Dong et al. 2008, 2009; Wang and Li 2009), of the study area around SCS can be divided into three stages (Table 1): (1) pre-rift stage (during Mesozoic), (2) syn-rift stage (from Mesozoic to the middle Oligocene), and (3) post-rift stage (after middle Oligocene). During the pre-rift stage, the South
China margin is thought to be an active continental margin. After the pre-rift stage, rifting accompanied by uplift and erosion of the rifted margin lasted from the Late Cretaceous to Early Oligocene. The SCS developed into the post-rift stage after the middle Oligocene and is further subdivided into the drifting stage and a post-drift stage (Lüdmann and Wong 1999).

The SCS seafloor spreading occurred during the drifting stage from the middle Oligocene to the Middle Miocene. The beginning of the drift phase, oriented north-south, is marked by a major breakup unconformity (BUU; Zhu et al. 1999; Zhou et al. 2006; Wang and Li 2009; Table 1). Marine magnetic anomalies in the SCS were identified to be from anomalies 11 to 5d (Taylor and Hayes 1983). This interpretation was modified as anomalies 11 to $5 \mathrm{c}$ according to a later study by Briais et al. (1993). Therefore, this drifting phase was placed from the end of the Early Oligocene through to the beginning of the Middle Miocene (30 - $16 \mathrm{Ma}$, anomalies 11 to 5c), if the anomalies are calibrated with the new geomagnetic time scale by Gee and Kent (2007). With the cessation of seafloor spreading, the deep SCS Basin and its adjacent continental margins started to subside as a consequence of the thermal relaxation of the

Table 1. Seismic stratigraphy, lithology, sea-level curve and major tectonic events of the study area (summarized from Haq et al. 1987; Zhu et al. 1999, 2012; Pang et al. 2005; Li et al. 2009). (Color online only)

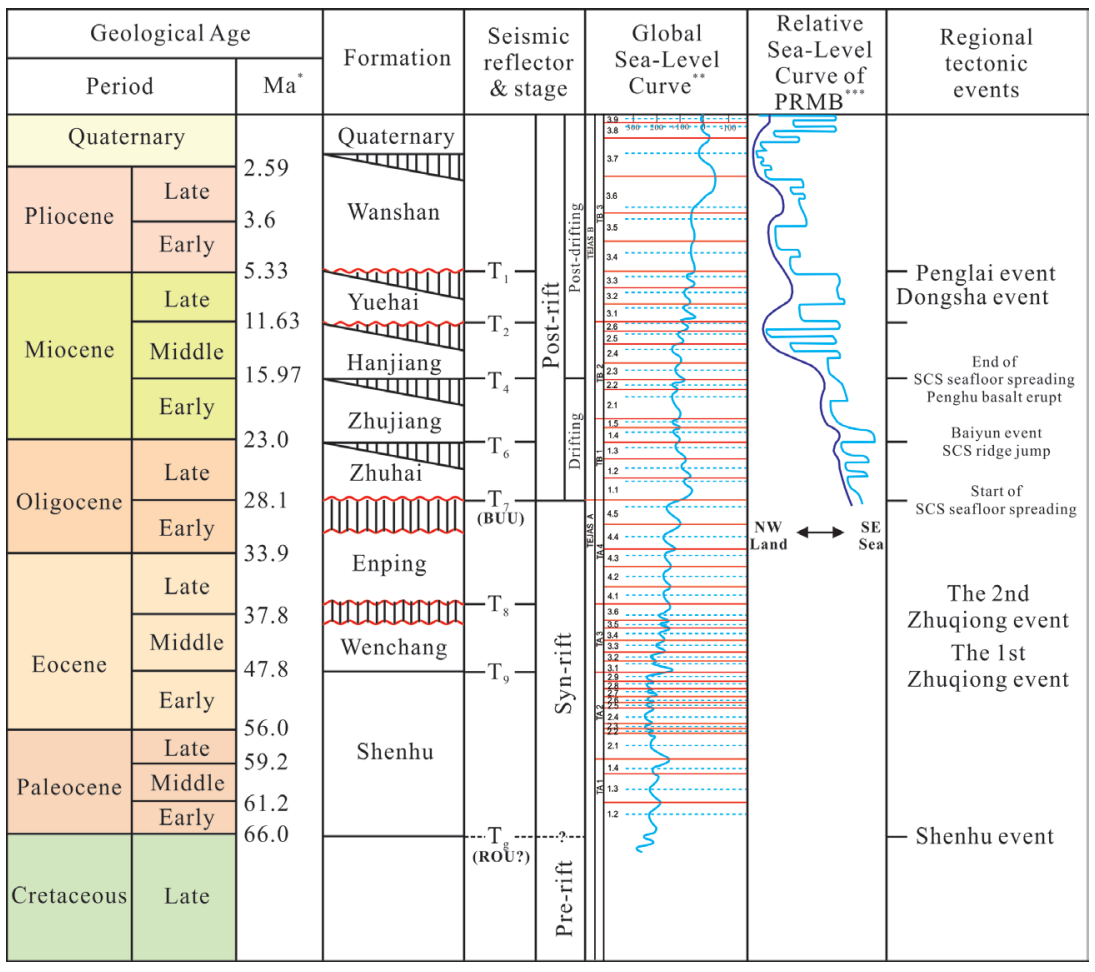

Note: BUU: breakup unconformity; ROU: rift onset unconformity.

* Age from Gradstein et al. (2012).

** Global sea-level curve from Haq et al. (1987).

*** Relative sea-level curve of PRMB from Pang et al. (2005). 
oceanic lithosphere during the post-drifting stage (Taylor and Hayes 1983; Lüdmann and Wong 1999; Wang and Li 2009; Table 1).

The distribution of middle to late Mesozoic (150 - $90 \mathrm{Ma}$ ) granites in the northern SCS continental margin is well documented and indicates that granitic magmatism was active form the Jurassic to Cretaceous periods at a convergent setting (e.g., Li 2000; Chen et al. 2008, 2010; Li et al. 2012). Meanwhile, Chen et al. (2010) reported a series of volcanic rocks including rhyolite, dacite, and andesite dated from 100 - $55 \mathrm{Ma}$ along the SE coastal range of China. They suggested that the magmatism was continuous from the Late Cretaceous to the Paleocene. During the Cenozoic, in the area surrounding the SCS, Cenozoic magmatic rocks are reported from South China to Hainan Island and the Indochina Peninsula (Barr and MacDonald 1981; Chung et al. 1994; Nguyen et al. 1996; Lee et al. 1998).

The published seismic profiles from the northern SCS (Zhou et al. 1995, 2006, 2008) indicate that the Mesozoic basement and the Cenozoic sediment and formation were separated by seismic reflection $\mathrm{T}_{\mathrm{g}}(\sim 66 \mathrm{Ma}$; Table 1$)$. For the geological evolution of the SCS margin in the Cenozoic, the seismic reflector $\mathrm{T}_{7}(\sim 30 \mathrm{Ma})$ separated the syn-rift stage from the post-rift stage around the middle Oligocene. In addition, the seismic reflection $\mathrm{T}_{4}(\sim 16 \mathrm{Ma})$ in the postrift stage separates the drifting stage from the post-drifting stage around the Middle Miocene (Table 1).

There are several large sedimentary basins developed during the Cenozoic along the margins of the SCS. The basins are characterized by episodic rifting, clockwise rotation of the rifts, a westward younging of the breakup unconformity, and intensifying crustal extension to the east (Zhou et al. 1995). In the study area, the Pearl River Mouth Basin (PRMB), the Chaoshan Depression, the Tainan Basin, and the Dongsha-Penghu Uplift are the four major geological units and are adjacent to each another (Figs. 1 and 2, B-B' profile). The geological evolution of the PRMB can be divided into three main phases by subsurface geological data (Feng and Zhang 1982; Jin et al. 1984; Guong et al. 1989; Yu 1994; Dong et al. 2009). The first phase is basement rifting and basin subsidence from the Late Cretaceous to the middle Oligocene. The subsidence was dominated by the deposition of the terrestrial Shenhu, Wenchang, and Enping formations during the rifting phase (Table 1). After the middle Oligocene, with the advent of seafloor spreading, the sea encroached onto the continental margin and a marine paleoenvironment was established ( $\mathrm{Li}$ 1984; Wu 1988; Guong et al. 1989; Feng et al. 1992). During the second phase, the faulting, subsidence and deposition occurred within the subbasins from the middle Oligocene to the Middle Miocene (Wang et al. 2003). Subsequent to the third phase was the subsidence and filling of the entire basin since the Middle Miocene (Wang et al. 2003). The Chaoshan Depression, located in the southwest of the study area, is regarded as a relict Mesozoic basin with one well drilling report (Wang et al. 2003). The Tainan Basin located in the northeast of the study area has good potential for petroleum. Reflection seismic and well data suggest that the Tainan Basin is a Cenozoic rift basin filled with sediments from the Upper Oligocene to the Quaternary that deposited unconformably on the Mesozoic terrestrial sediments. In most seismic sections, there is no clear acoustic basement. However, there is a sharp angular unconformity below the Cenozoic strata. The angular unconformity represents a stratigraphic hiatus between the Late Cretaceous and the Early Oligocene (Lee et al. 1993; Tzeng 1994; Lin et al. 2003; Li et al. 2007, 2008). The Dongsha-Penghu Uplift is a basement high located in the northwest of the study area and is subparallel to the continental margin. South of the uplift, the Tainan Basin and the Chaoshan Depression extend from the northeast to the southwest. The Dongsha-Penghu Uplift connects the Peikang basement high to onshore Taiwan (to the north) and has the same features as an outstanding positive magnetic anomaly belt (Tzeng 1994; Huang et al. 2004; Fig. 2).

\section{DATA AND METHOD}

This study used more than $7000 \mathrm{~km}$ of multi-channel industrial seismic profiles from the western Dongsha-Penghu Uplift (Fig. 1). Seismic data in SEGY format come from two sources, Chinese Petroleum Corporation, Taiwan (CPC, Taiwan), and Tainan-Chaoshan Petroleum Operating Company (TCPOC). Seismic reflections are correlated with well data from MZ-1-1 (Hao et al. 2001; Yan and Liu 2004; Yan et al. 2014; Fig. 3) and interpretations of nearby seismic profiles by Zhou et al. $(1995,2006,2008)$ and Zhu et al. (1999). Drilling and logging data of well MZ-1-1 were acquired by industrial standards and are provided by TCPOC. We compiled the seismic stratigraphy, lithology, sea-level curve and major tectonic events of the study area from the literature (global sea-level curve from Haq et al. 1987; the geological time scale from Gradstein et al. 2012; other information from Zhu et al. 1999, 2012; Li et al. 2009; Table 1). The procedures for determining stratigraphy from seismic data involve seismic sequence analysis, seismic facies analysis, and interpretation of lithofacies and depositional environments (Vail 1987). The working procedures to separate the seismic sequences are based on defining the genetic reflection packages (referred to as seismic sequences and seismic systems tracts) by identifying discontinuities on the basis of reflection termination patterns. These are used to determine the depositional environment from the characteristics of the seismic reflections (Vail 1987). This study also collected the cutting samples from the well MZ-1-1 for the detrital zircon $\mathrm{U}-\mathrm{Pb}$ dating to better constrain the sedimentation ages of well MZ-1-1. The youngest age given by detrital zircon $\mathrm{U}-\mathrm{Pb}$ dates may be used to indicate the oldest possible age for the timing of deposition of the strata (Bowring et al. 2006; 
Gehrels et al. 2006). The detrital zircon ages can be used in conjunction with the bio-stratigraphy results to constrain the formation timing of the strata. Based on the interpretation of the seismic profiles and the age control from well MZ-1-1 (Fig. 3 and Table 2), we have summarized the depositional history and the temporal and spatial extents of the Mesozoic structural inversion. In addition, the interpretation will be discussed for tectonic implications and will be used to propose a regional tectonic evolution model.

\section{RESULTS}

\subsection{Lithology}

The geological description of lithologies and depositional environments of MZ-1-1 can be divided into 6 sections (Fig. 3). And three distinct tectonostratigraphic units (I, II, and III) can be identified from seismic profiles across the northern continental margin of the SCS, featuring different reflection patterns and internal structures (Table 2). The tectonostratigraphic units I, II, and III (from old to young) are separated by two major sequence boundaries $\left(\mathrm{T}_{\mathrm{LK} / \mathrm{EK}}\right.$ and $\mathrm{T}_{7}+\mathrm{T}_{\mathrm{g}}$; Fig. 4). Based on seismic facies recognition and the drilling results from well MZ-1-1 (Li et al. 2007, 2008; Shi and $\mathrm{Li}$ 2012; Yan et al. 2014), we infer that these tectonostratigraphic units correspond to distinct tectonic and depositional environments. Tectonostratigraphic units I to III are from the Jurassic pre-rift stage with a granitic acoustic basement and littoral to neritic to abyssal sediment deposition, the Cretaceous pre-rift stage is mainly paralic to terrestrial sedimentary facies, and the post-rift stage with mainly marine sedimentary facies, respectively (Sangree and Widmier 1978; Vail 1987; Vail and Wornardt 1991; Lüdmann and Wong 1999; Li et al. 2007, 2008).

Tectonostratigraphic unit I is the Mesozoic [Early Cretaceous to Jurassic(?)] acoustic basement formed during the pre-rift stage including two distinct reflection patterns. The major one is a chaotic reflection pattern with slightly variable frequency, low-moderate intermediate intensity, and low continuity. The other one is a parallel reflection pattern with slightly variable frequency, high intensity and high continuity (Table 2). Based on the igneous rock sample from the bottom of well MZ-1-1, the dominant rock type at the acoustic basement is most likely Mesozoic granite (Li et al. 2007, 2008; Shi and Li 2012; Yan et al. 2014). The parallel reflection pattern may be interpreted as a sedimentary formation (Sangree and Widmier 1978). The parallel reflection pattern can be correlated with the Early Cretaceous sedimentary formation based on the biochronology (Hao et al. 2001; Yan and Liu 2004; Yan et al. 2014) and detrital zircon ages from the cuttings of well MZ-1-1. The lower section of tectonostratigraphic unit I appear to be granite and diorite (Fig. 3). The middle section of tectonostratigraphic unit I represented the grey to black laminar mud stone and silt stone interbedded with sand stone, limestone, and oolitic limestone, and mud stone is rich in organic clast (Fig. 3). The upper section of tectonostratigraphic unit I represented the radiolarite interbedded with basalt, grey to black laminar mud stone and silt stone (Fig. 3). Tectonostratigraphic unit I experienced an anticline-shaped basement high due to the reverse faulting and a strong erosional surface that is indicated by a major unconformity $\mathrm{T}_{\text {LK/EK }}$ (Fig. 4). The unconformity $\left(\mathrm{T}_{\mathrm{LK} / \mathrm{KK}}\right)$ formed near the Early Cretaceous and Late Cretaceous boundary (with moderate-strong amplitude and a moderate-good continuous reflection pattern) and separates the lower and middle seismic units (Table 2).

Tectonostratigraphic unit II (pre-rift stage of Late Cretaceous) is characterized by subparallel, locally chaotic and wavy internal reflection patterns, with variable frequency, highly variable intensity and intermediate to high continuity (Table 2), which is typical of non-marine deposits (Sangree and Widmier 1978). Based on the cutting analysis from well MZ-1-1, the lower section of tectonostratigraphic unit II are basic extrusive rocks with secondary rhyolites and beds of muds, sands, conglomerates, and marl stones (Fig. 3). The middle section of tectonostratigraphic unit II represents the grey mud stone with lamination, silt stone, and sand stone, and little organic clast without gypsum cementation (Fig. 3). The upper section of tectonostratigraphic unit II represented the mulberry muds, silts, and sand stones with little marl stones, and gypsum cementation development (Fig. 3). Tectonostratigraphic unit II was deposited on the major unconformity $\left(\mathrm{T}_{\mathrm{LK} / \mathrm{EK}}\right)$ after tectonostratigraphic unit I during Late Cretaceous according to the biochronology (Hao et al. 2001; Yan and Liu 2004; Yan et al. 2014) and detrital zircon ages of cuttings from well MZ-1-1 (Fig. 3). Tectonostratigraphic unit II represents an anticline fold and was bounded on top by a prominent unconformity $\left(\mathrm{T}_{7}+\mathrm{T}_{\mathrm{g}}\right.$; Fig. 4 and Table 2$)$. This unconformity $\left(\mathrm{T}_{7}+\mathrm{T}_{\mathrm{g}}\right)$ is a significant angular unconformity that is nearly parallel to the seafloor and has a strong amplitude with good continuity and shows erosional truncation below it (Table 2). Based on the correlation with the seismic profiles of PRMB (Feng and Zhang 1982; Jin et al. 1984; Guong et al. 1989; Zhu et al. 1999; Dong et al. 2009), the $\mathrm{T}_{7}+\mathrm{T}_{\mathrm{g}}$ formed after the pre-rift and syn-rift stages and can be identified as the break-up unconformity merging riftonset unconformity of Falvey (1974).

Tectonostratigraphic unit III (post-rift stage: drifting stage and post-drifting stage in Cenozoic) is characterized by a parallel-subparallel, locally wavy internal reflection pattern with slightly variable frequency, transparent and locally low-moderate intensity and high continuity (Table 2). This seismic facies may be attributed to coastal to marine sediments in which siltstones or mudstones and sandstones dominate and were deposited during the post-rift stage (Neogene to Quaternary; Hao et al. 2001, 2009; Yang et al. 2008). The post-rift stage seismic characteristics in this area are similar to those from nearby areas, e.g., the Tainan Basin (Lee et al. 1993) and PRMB (Wang and Sun 1994). 


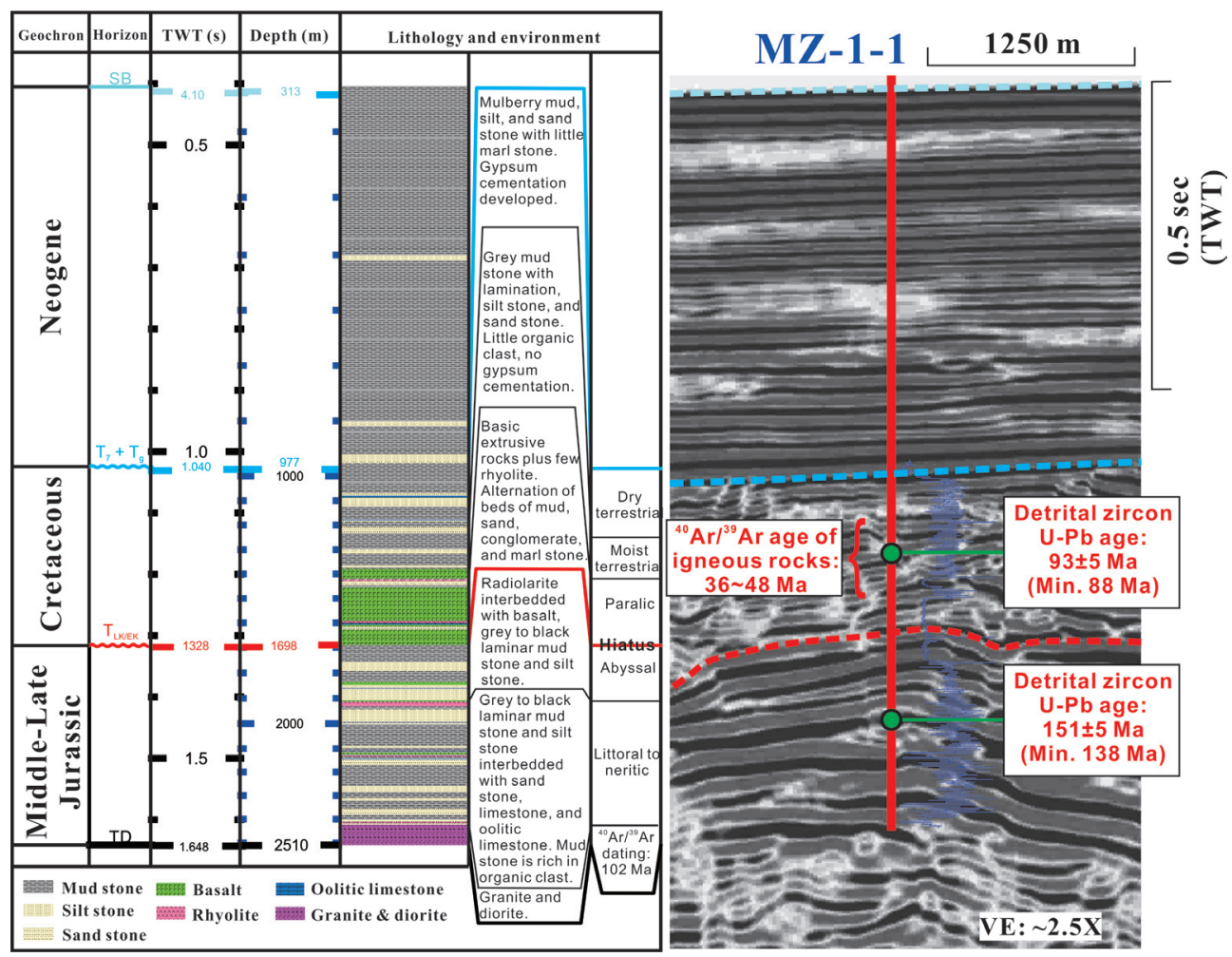

Fig. 3. Summaries of the lithology, depositional environment, and geochron of well MZ-1-1 from the drilling report (Yan and Liu 2004; Hao et al. 2009; Shi and Li 2012) in the seismic profile cross the well. The blue and red dash lines in the seismic profile show the tectonostratigraphic unit boundaries $\left(\mathrm{T}_{7}+\mathrm{T}_{\mathrm{g}}\right.$ and $\left.\mathrm{T}_{\mathrm{LK} / \mathrm{FK}}\right) .{ }^{40} \mathrm{Ar} /{ }^{39} \mathrm{Ar}$ age of igneous rocks (Lo 2004) and detrital zircon age from this study were shown in the right hand side. (Color online only)

Table 2. Seismic facies, sequences and reflection patterns with tentative ages of major sequence boundaries of the study area. (Color online only)

\begin{tabular}{|c|c|c|c|c|c|c|}
\hline $\begin{array}{c}\text { Tectonostratigraphic } \\
\text { unit }\end{array}$ & Period & $\begin{array}{c}\text { Internal reflection } \\
\text { pattern }\end{array}$ & Frequence & Intensity & Continuity & Example \\
\hline III & Cenozoic & $\begin{array}{l}\text { Parallel to subparallel, } \\
\text { locally wavy }\end{array}$ & $\begin{array}{l}\text { Slightly } \\
\text { variable }\end{array}$ & $\begin{array}{l}\text { Transparent and } \\
\text { locally low to } \\
\text { moderate }\end{array}$ & High & 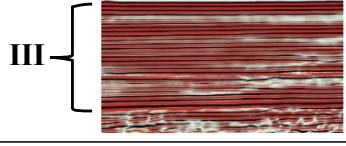 \\
\hline II & Late Cretaceous & $\begin{array}{l}\text { Subparallel, locally } \\
\text { chaotic and wavy }\end{array}$ & variable & High variable & $\begin{array}{l}\text { Intermediate- } \\
\text { high }\end{array}$ & 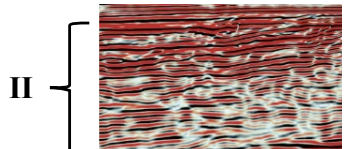 \\
\hline \multirow{2}{*}{ I } & \multirow{2}{*}{$\begin{array}{l}\text { Early Cretaceous } \\
\text { to Jurassic? }\end{array}$} & Chaotic & $\begin{array}{l}\text { Slightly } \\
\text { variable }\end{array}$ & $\begin{array}{l}\text { Low to moderate } \\
\text { intermediate }\end{array}$ & Low & \multirow{2}{*}{ 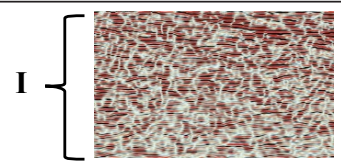 } \\
\hline & & Parallel & $\begin{array}{l}\text { Slightly } \\
\text { variable }\end{array}$ & High & High & \\
\hline \multicolumn{2}{|c|}{$\begin{array}{c}\text { Tectonostratigraphic unit boundary and } \\
\text { age }\end{array}$} & \multicolumn{4}{|c|}{ Reflection pattern } & Example \\
\hline \multicolumn{2}{|c|}{$\begin{array}{c}\mathrm{T}_{7}+\mathrm{Tg} \text { (boundary between Cenozoic and } \\
\text { Mesozoic) }\end{array}$} & \multicolumn{4}{|c|}{$\begin{array}{l}\text { Nearly parallel to seafloor, strong amplitude with good continuity, } \\
\text { erosional truncation below }\end{array}$} & 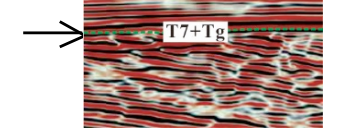 \\
\hline \multicolumn{2}{|c|}{$\begin{array}{c}\mathrm{T}_{\mathrm{LK} / \mathrm{KK}} \text { (boundary between Late and Early } \\
\text { Cretaceous) }\end{array}$} & \multicolumn{4}{|c|}{ Moderate to strong amplitude, moderate to good continuity } & $\mathrm{Nan=N}$ \\
\hline
\end{tabular}




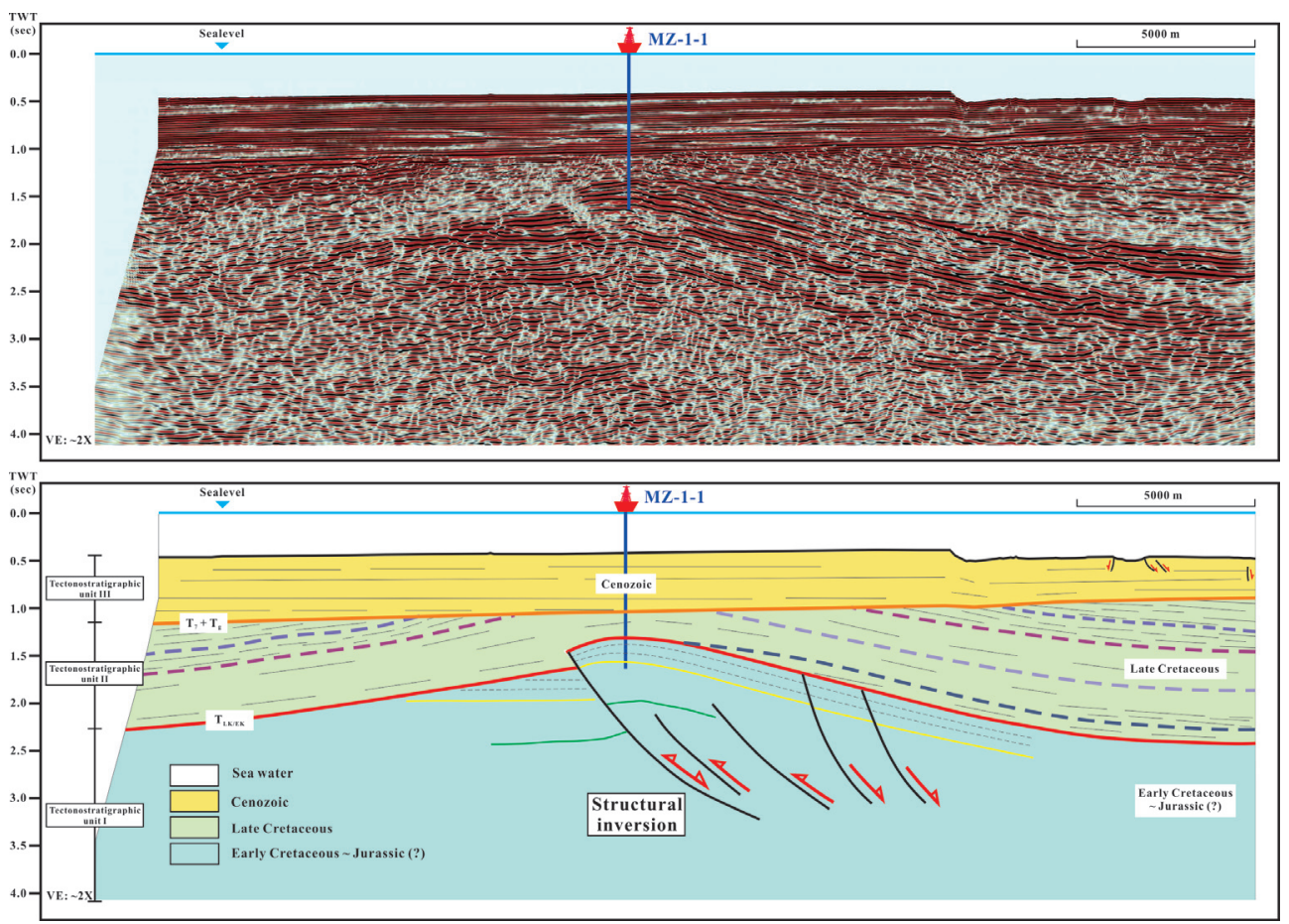

Fig. 4. Geological interpretation of multi-channel seismic profiles across well MZ-1-1 as the profile c01 running from the northwest to the southeast. The seismic sequence age was correlated with the well MZ-1-1. The seismic sequence facies and reflection pattern are shown in Table 2. Highlight of yellow and green for the marker beds with different formation time indicated the relative movements. The origin and red lines indicate the unconformities $\mathrm{T}_{7}+\mathrm{T}_{\mathrm{g}}$ and $\mathrm{T}_{\text {LK/EK }}$. (Color online only)

\subsection{Zircon Ages}

The age controls of well MZ-1-1 (Table 3) in previous studies are from fossil records (Hao et al. 2001; Yan and Liu 2004; Yan et al. 2014) and ${ }^{40} \mathrm{Ar} /{ }^{39} \mathrm{Ar}$ dating of igneous rocks (Lo 2004; Fig. 3). According to the analysis of limited benthonic and planktonic foraminiferas, dinoflagellates, and pollens collected from well MZ-1-1, the depth between 1350 and $2400 \mathrm{~m}$ can be identified as Mesozoic strata. And the radiolarians between $\sim 1700$ and $\sim 1900 \mathrm{~m}$ can be assigned as the Jurassic age. However, the ages of the whole rock ${ }^{40} \mathrm{Ar} /{ }^{39} \mathrm{Ar}$ dating range from 36.2 - 48.4 Ma that collected from the side wall cores between depth of $\sim 1400$ and $\sim 2400 \mathrm{~m}$ of well MZ-1-1. The ${ }^{40} \mathrm{Ar} /{ }^{39} \mathrm{Ar}$ ages are totally different from the biochronology, therefore, we collected the cutting samples and separated the detrital zircons for further analysis.

Two samples were collected from cuttings of the well MZ-1-1, and the depths of cuttings are 1250 - 1350 and 1950 - $2050 \mathrm{~m}$ (Fig. 3). Zircon grains were separated using standard techniques of crushing, grinding, sieving, magnetic and heavy liquid separation, and then purified by hand picking under a binocular microscope. Zircons from most samples are clear, euhedral to rounded grains and exhibit elongated or stubbed prisms. After the hand picking, the zircon separates were mounted in epoxy and polished to approximately half the mean grain thickness. The internal structures of the zircons and the presence of inclusions were checked using transmitted and reflected optical microscopy. Cathodoluminescence (CL) images were used to demonstrate the internal zonings of zircons and to select optimum spot locations for in-situ U-Pb dating analysis (Lan et al. 2009).

Zircon $\mathrm{U}-\mathrm{Pb}$ isotopic analyses were performed using the laser ablation-inductively coupled plasma mass spectrometry (LA-ICPMS). The analyses of LA-ICPMS for samples were performed using an Agilent ICPMS 7500cx with the Ar and He carrier gas, and equipped with a New Wave UP-213 laser ablation system with the He carrier gas at National Chung Cheng University, Taiwan. Laser diameter is $25 \mu \mathrm{m}$. As for the measured $\mathrm{Pb}$ isotopes, common $\mathrm{Pb}$ correction is performed by ComPbcorr (Andersen 2002). GJ $(600 \pm 5 \mathrm{Ma})$ and PL $(337 \pm 10 \mathrm{Ma})$ reference zircon was measured periodically during the analysis. The detail of the method is described in Orihashi et al. (2008).

A total of 278 zircons with $\geq 88 \mathrm{Ma}$ (Sample 01) and $\geq 138 \mathrm{Ma}$ (Sample 02) minimum U-Pb ages are obtained from the 2 cutting samples; the U-Pb analytical results are listed in Appendix. The U-Pb zircon ages of Sample $01 \geq$ $88 \mathrm{Ma}$ (cutting depth is $\sim 1300 \mathrm{~m}$ ) and Sample $02 \geq 138$ Ma (cutting depth is $\sim 2000 \mathrm{~m}$ ) are plotted as histograms in Figs. 5a and b, which show the major age groups of $93 \pm 5$ Ma (Sample 01) and $195 \pm 5$ Ma (Sample 02) ages, respectively (Fig. 5). Zircons separated from clastic rocks yield 
useful constraints on the depositional age (Gehrels et al. 2006). The youngest detrital zircons provide a maximum age of deposition as well as provide information on the age of the source terrains providing the detritus (Bowring et al. 2006) because the zircons must have been formed earlier than their erosion and sedimentation into basins. Therefore, the detrital zircon ages of Samples 01 and 02 indicated the oldest depositional ages are Late Cretaceous and Early Cretaceous, respectively (Fig. 3). The U-Pb zircon dating results of Sample 02 can be used to modified that the $T_{K / J}$ biochronology proposed by Hao et al. (2001), Yan and Liu (2004), and Yan et al. (2014; Fig. 3) should be $\mathrm{T}_{\mathrm{LK} /}$ boundary (i.e., between Late Cretaceous and Early Cretaceous). It also can provide a better age control for the seismic profile interpretations.

The detrital zircon ages of this study agree better with the biochronology (Hao et al. 2001; Yan and Liu 2004; Yan et al. 2014) than ${ }^{40} \mathrm{Ar} /{ }^{39} \mathrm{Ar}$ age of igneous rocks (Lo 2004). It is likely to indicate the plateau ages of each ${ }^{40} \mathrm{Ar} /{ }^{39} \mathrm{Ar}$ dating results were used to constrain the timing of each thermal event, and do not indicate the depositional age of the strata.

\subsection{Tectonics}

Seismic profiles from the western Dongsha-Penghu Uplift (Fig. 4) show inverted basement features such as eroded anticlinal structures. The inversion structures were initially interpreted as the reactivation of normal faults. An example of the inversion structures is the basement and the strata above it (tectonostratigraphic unit I and II) appears to be passing through well MZ-1-1(Fig. 4). There is a prominent anticlinal fold in the tectonostratigraphic unit II and reverse faults in the tectonostratigraphic unit I, and the top of the anticline is truncated by the rift-onset (and/or breakup) unconformity $\left(\mathrm{T}_{7}+\mathrm{T}_{\mathrm{g}}\right)$. The correlation of the offset from the reflectors in the tectonostratigraphic unit I (highlighted in yellow and green for the marker beds with different formation ages; Fig. 4) exhibited displacements due to faulting. The displacements indicating that the strata were cut through by the normal faults and reverse faults. The displacements of reflectors below unconformity $\mathrm{T}_{\mathrm{LK} / \mathrm{EK}}$ show that there was an inversion event before the unconformity formed (Fig. 4). The normal fault systems trend NE-SW

Table 3. Summary of age data from well MZ-1-1.

\begin{tabular}{|c|c|c|c|c|c|}
\hline \multicolumn{2}{|l|}{ Biochronology 1} & \multicolumn{2}{|c|}{${ }^{40} \mathrm{Ar} /{ }^{39} \mathrm{Ar}$ age of igneous rocks ${ }^{2}$} & \multicolumn{2}{|c|}{ Detrital zircon U-Pb Geochronology ${ }^{3}$} \\
\hline Depth (m) & Relative age & Depth (m) & Total gas age $(\mathrm{Ma} \pm 2 \sigma)$ & Depth (m) & $\mathrm{U}-\mathrm{Pb}$ age $(\mathrm{Ma} \pm 2 \sigma)$ \\
\hline$\sim 1350$ (Benthonic and planktonic foraminifera) & Mesozoic & 1397 & $37.6 \pm 0.5$ & $\sim 1300$ & $93 \pm 5$ \\
\hline$\sim 1700$ - 1900 (Radiolaria) & Jurassic & 1596.5 & $31.3 \pm 0.6$ & & Min. 88 \\
\hline$\sim 1800$ (Foraminifera) & & & & & \\
\hline$\sim 1950$ (Dinoglagellate) & & 2120 & $51.7 \pm 0.8$ & & $151 \pm 5$ \\
\hline$\sim 2100$ (Benthonic foraminifera) & & 2416.5 & $54.9 \pm 0.6$ & & \\
\hline$\sim 2200$ - 2400 (Pollen) & Mesozoic & 2443.5 & $46.9 \pm 0.7$ & $\sim 2000$ & Min. 138 \\
\hline$\sim 2400$ (Benthonic foraminifera) & & 2454 & $101.1 \pm 1.1$ & & \\
\hline
\end{tabular}

Note: 1: Hao et al.2001; Yan and Liu 2004; Yan et al.2014. 2: Lo 2004. 3: This study.

(a)

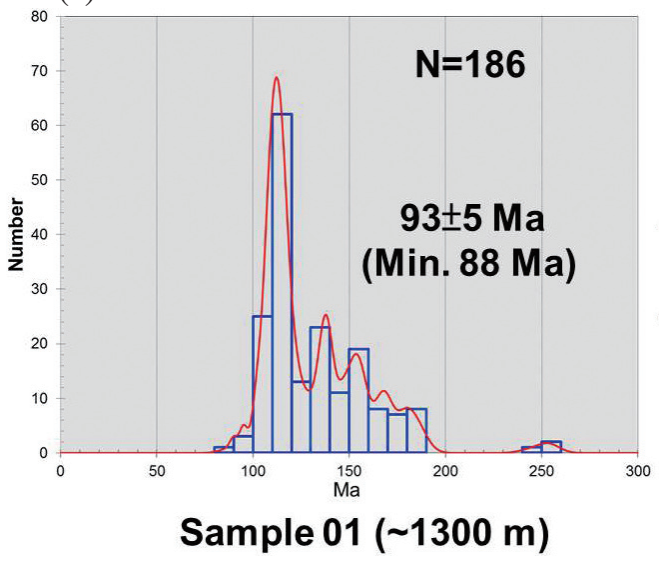

(b)

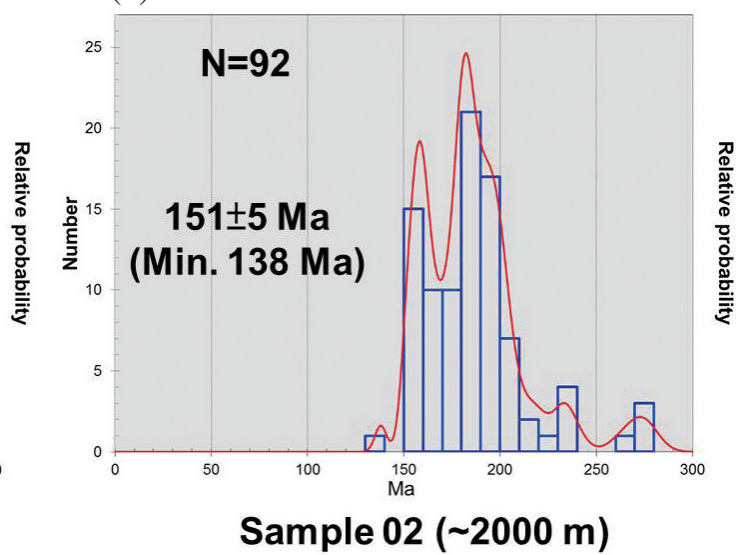

Fig. 5. Histogram showing U-Pb zircon ages distributions of Sample 01 (cutting depth is $\sim 1300 \mathrm{~m}$ ) and Sample 02 (cutting depth is $\sim 2000 \mathrm{~m}$ ). (Color online only) 
and dip to the SE and cut the Mesozoic basements of the northern SCS continental margins. These faults maybe caused by rifting during the Late Mesozoic to Early Cenozoic (Taylor and Hayes 1983; Dong et al. 2008, 2009; Wang and Li 2009). The dip angle of the reverse fault planes in the tectonostratigraphic unit I can be calculated using the timedepth equation of well MZ-1-1. The horizontal and vertical distances of the faults were calculated by applying the time-depth equation ( $\mathrm{y}=2474.5 \mathrm{x}-1572.5, \mathrm{R}^{2}=0.9998, \mathrm{x}$ is two-way time and y is depth) of well MZ-1-1 (Fig. 4). The dip angles of the main reverse fault planes are between 40 to 60 degrees. These angles are too steep and unreasonable for thrust faults (Davis et al. 2012). The reverse faults with steep angles were probably formed by inversion of normal faults that were formed during the rifting of the Mesozoic basement. Therefore, these high-angle reverse faults are most likely formed by reactivation of the normal faults in the Mesozoic basement due to the inversion event. From Fig. 4, there are normal faults that were not reactivated to reverse faults by this inversion event. They may have experienced only minor reactivation along the fault planes around both sides of the anticline during the compression (Fig. 4). The above tectonostratigraphic unit II was folded by the contractional event. It is likely that, due to the brittle nature of the tectonostratigraphic unit I, fractures and displacements took place due to the inversion event. As for the more ductile tectonostratigraphic unit II, only folds developed due to the inversion. Thus, reverse faulting of tectonostratigraphic unit I and folding of tectonostratigraphic unit II were coeval. The timing of the inversion event must be at the end of the formation time of the tectonostratigraphic unit I and before the formation time of the tectonostratigraphic unit III, which is approximately in the Late Cretaceous based on the age control of the well MZ-1-1. In the area of profile c01 (Fig. 4), the folds of tectonostratigraphic unit II were truncated by the regional erosional surface defined as the rift-onset unconformity $\mathrm{T}_{\mathrm{g}}$, that may imply that the inversion event ceased before the formation of the rift-onset unconformity $\mathrm{T}_{\mathrm{g}}(\sim 66 \mathrm{Ma})$. Conclusively, the inversion event possibly started after the Early Cretaceous, developed during the Late Cretaceous, and ended before the Cenozoic.

The basement inversion scenario is similar to the tectonic inversion and basement buttressing in the central Appalachian Blue Ridge province (Bailey et al. 2002). The possible history of the structural inversion in the western Dongsha-Penghu Uplift began with the contraction displacement on reactivated faults. The contraction displacement pushed the hanging-wall up relative to the footwall and may even have moved the hanging-wall higher than its pre-extensional position. The inversion changed the Mesozoic basement and pre-rifting sedimentary units to be lifted and folded as anticlines. Then, the major anticline of basement (tectonostratigraphic unit I) and its overlying strata (tectonostratigraphic unit II) were exposed. Subsequently, erosion of the folded tectonostratigraphic unit II generated a prominent unconformity (rift-onset unconformity $\mathrm{T}_{\mathrm{g}}$ ).

The areal distribution of this structural inversion can be identified from seismic profiles in the study area (Figs. 6 and 7). The main structural inversion is only distributed in the western Dongsha-Penghu Uplift, with NESW structural trends (Figs. 6 and 7). Figure 6 shows five NW-SE trending seismic profiles including two in the SW of profile $\mathrm{c} 01$ (w01 and w02) and three in the NE of profile c01 (e01, e02, and e03). In Fig. 6, the blue dashed lines and red dashed lines show the two unconformities separating the three tectonostratigraphic units. The tectonostratigraphic unit I and II have an anticlinal structure caused by the structural inversion and is outlined by the pink ellipse between seismic profiles w01 to e02 (Fig. 7). The structural inversion cannot be identified in seismic profiles w02 and $\mathrm{e} 03$ (Fig. 6). The structural contour of $\mathrm{T}_{\mathrm{LK} / \mathrm{EK}}$ revealed the areal extent of the structural inversion and was trending in a NE direction with a width of $\sim 100 \mathrm{~km}$ (Fig. 7). If the areal distribution $(\sim 100 \mathrm{~km})$ of the structural inversion can be used to infer the scale of the collision event, the size of collider that collided with the northern continental margin of the SCS may be at the scale of $100 \mathrm{~km}$.

The inversion event reactivated some normal faults into high-angle reverse faults and generated the anticline. Based on the structural inversion interpretation of seismic profiles and the NE-SW trending distribution, the contractional event occurred with a NW-SE directed compressive stress during the Late Cretaceous to Early Cenozoic. Currently, there is an extensional environment with rifting tectonic setting in the northern SCS continental margin (Dai et al. 1992; Martin et al. 1994; Chen et al. 1996; Yui et al. 1996; Li 2000). Thus, this structural inversion, possibly caused by a collision event around the Late Cretaceous, may coincide with the timing of the Mesozoic collision events between blocks (such as the Luconia-Dangerous Grounds, Palawan, Mindoro, Romblon, and Zamboanga areas, Paracel Islands, Macclesfield Bank, and Reed Bank) and northern continental margin of SCS as suggested by Faure et al. (1989), Li et al. (2007), Hall (2009, 2012), Hall et al. (2011), and Morley (2012).

After interpreting profile $\mathrm{c} 01$ with the well data of MZ$1-1$, we can summarize the depositional and tectonic evolution in the western Dongsha-Penghu Uplift area (Fig. 8). During the Jurassic to Early Cretaceous, the basement of the basin formed and sedimentary strata were deposited in this area. The area experienced tensional stress under a rifting tectonic framework and formed a series of normal faults in the tectonostratigraphic unit I. Near the end of Early Cretaceous, a tectonic event caused some normal faults of tectonostratigraphic unit I to reactivate into high-angle reverse faults and form the structural inversion which was later truncated by erosion. During Late Cretaceous, the structural inversion developed into an anticline with the syn-tectonic sediments deposited (tectonostratigraphic unit II) in a 

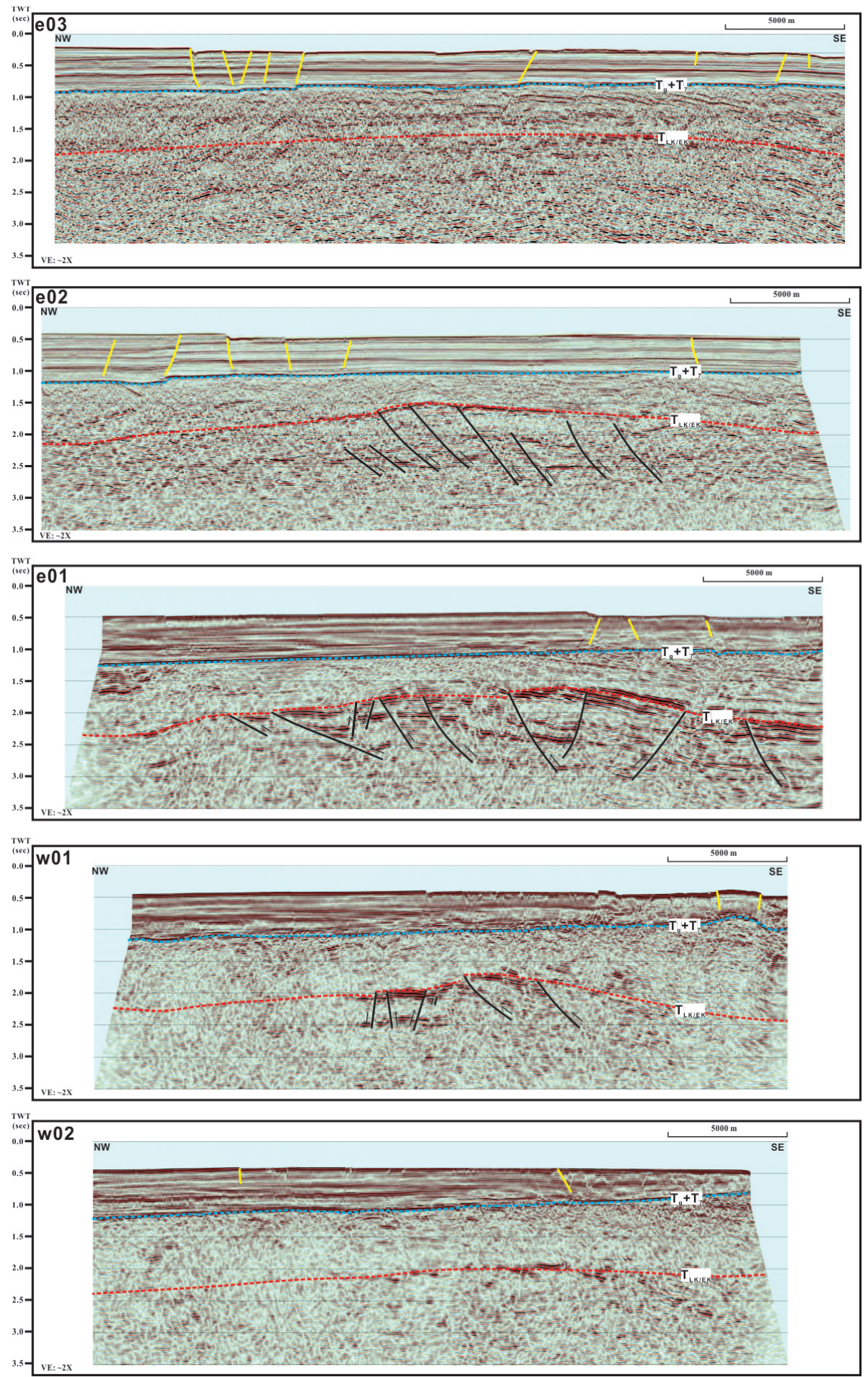

Fig. 6. Interpretation of five NW-SE seismic profiles (w01, w02, e01, e02, e03) showing the structural inversion in the western Dongsha-Penghu Uplift and Donsha Island. The blue and red dash lines in the seismic profile show the tectonostratigraphic unit boundaries $\left(\mathrm{T}_{7}+\mathrm{T}_{\mathrm{g}}\right.$ and $\left.\mathrm{T}_{\mathrm{LK} / \mathrm{EK}}\right)$. Note the structural inversion disappear in seismic profiles w02 and e03. The locations of the five seismic profiles were shown in Figs. 1 and 7. (Color online only) 


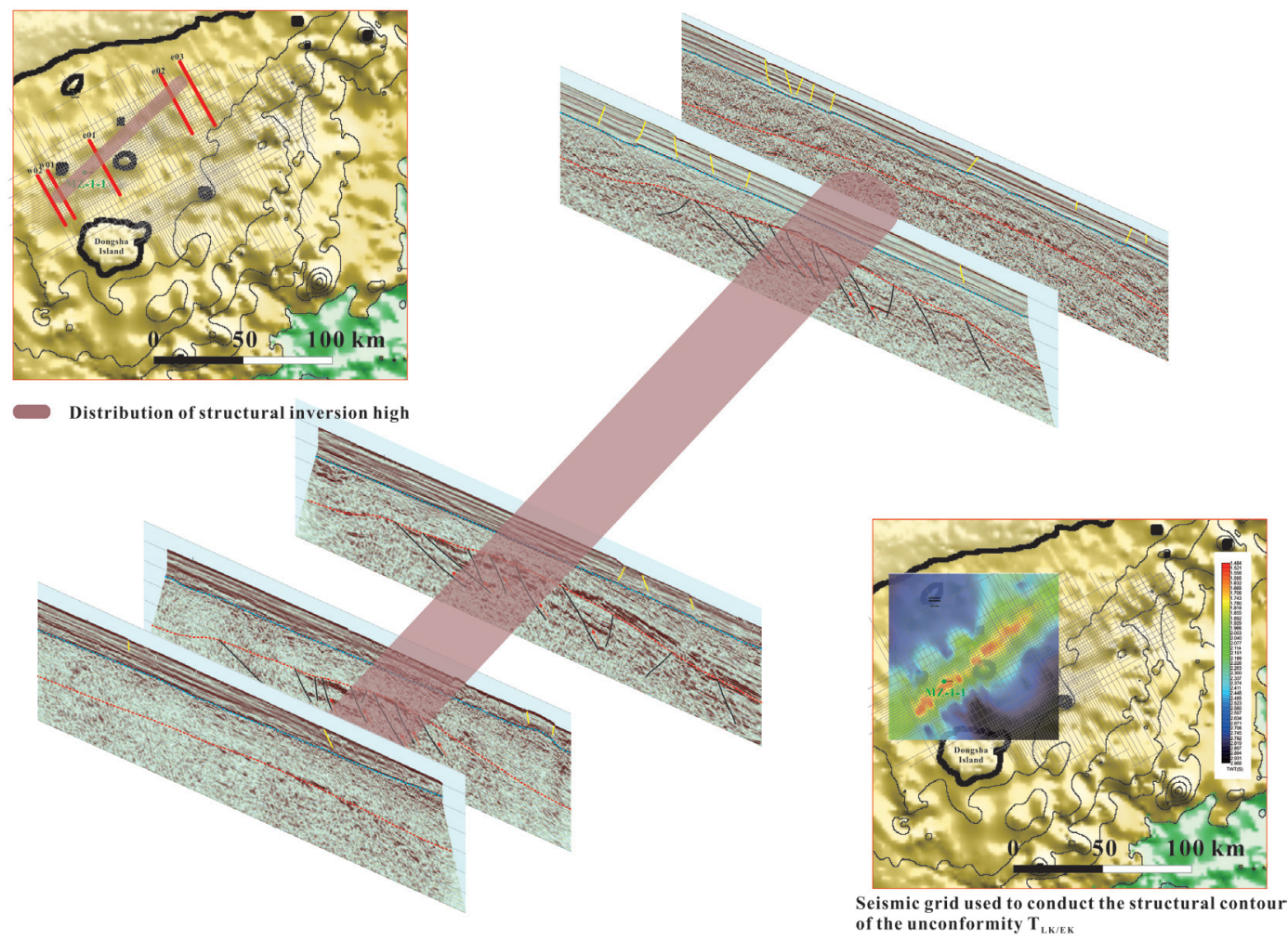

Fig. 7. Two-Way Time contour based on the interpretation of multi-channel seismic profiles showing the extent of the structural inversion in the western Dongsha-Penghu Uplift and Donsha Island. The extent width of the structural inversion is $\sim 100 \mathrm{~km}$. (Color online only)
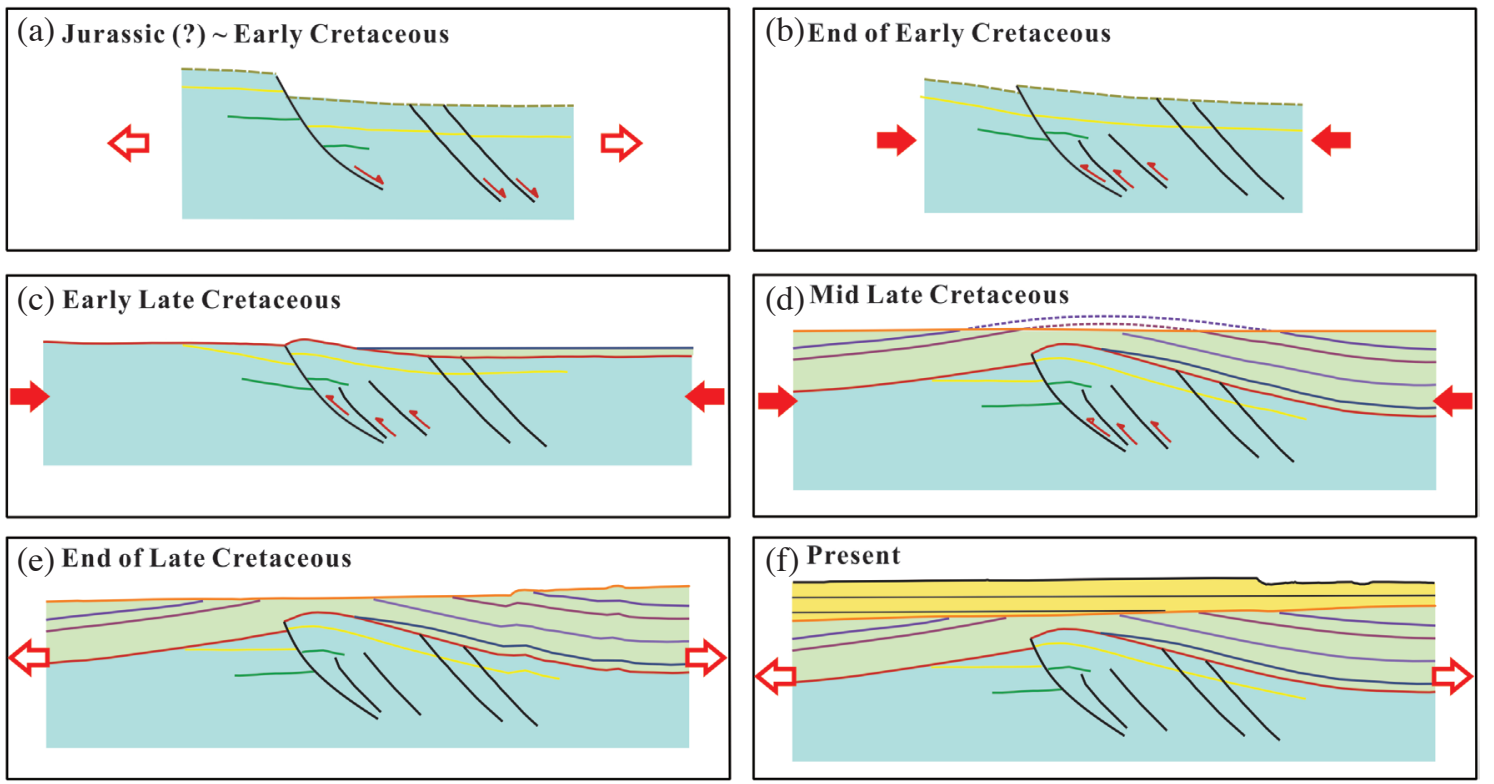

Fig. 8. Restoration of depositional and tectonic history from profile c01. (a) The overlying Early Cretaceous strata were deposited on the rifted Jurassic basement with normal faults in the extensional tectonic setting. (b) and (c) indicate that the structural inversion started and was truncated by the erosional surface in the end of Early Cretaceous, then the Late Cretaceous sediments were deposited on the unconformity $\mathrm{T}_{\mathrm{LK} / \mathrm{EK}}$. (d) The structural inversion formed an anticline of the syn-deposited sediments during the Late Cretaceous in the contractional tectonic setting resulting from the collision event. (e) The regional erosional surface, which can be defined as unconformity $\left(\mathrm{T}_{7}+\mathrm{T}_{\mathrm{g}}\right)$, truncated the anticline of the Mesozoic strata at the end of the Cretaceous. (f) The Cenozoic sediments were deposited from the Neogene to the present. (Color online only) 
contractional tectonic setting resulting from the collision event. During the latest Cretaceous, an erosional surface truncated the structural high (anticline) and is identified as an angular unconformity $\left(\mathrm{T}_{\mathrm{g}}\right)$. Then, the Cenozoic sediments were deposited mainly by aggradation on top of the angular unconformity.

\section{DISCUSSION}

To understand the nature of the collision that caused the inversion structure in the western Dongsha-Penghu Uplift of the northern SCS margin, we utilized palinspastic reconstructions to test possible hypotheses. We first simulated the flow-line of a point near the inversion structure. As the SCS opened, the point would move to the south following the direction of seafloor spreading (Fig. 9). This can be accomplished using the Euler poles published by Briais et al. (1993) based on the magnetic anomalies identification in the SCS. The absolute ages of the anomalies were adapted from Gee and Kent (2007). Prior to the seafloor spreading, this continental margin was probably highly extended. The published stretching factor and the extensional direction from previous studies ( $\beta$ values of Su et al. 1989; Zhou et al. 1995) were used to further constrain the paleogeography. Overall, the flow-line (Fig. 9) reveals that the Calamian Is- lands, located in the North Palawan block, may have drifted from the western Dongsha-Penghu Uplift to the present position following the spreading of SCS. Another flow-line in Fig. 9 is referred from different SCS magnetic anomalies interpretation of Barckhausen and Roeser (2004). They proposed a markedly different distribution of magnetic chrons of the South China Sea from that described by Taylor and Hayes (1983) and Briais et al. (1993), and alternatively indicate an earlier cessation of the spreading of the SCS at $20.5 \mathrm{Ma}$, indicating a fast spreading rate $\left(\sim 40 \mathrm{~mm} \mathrm{yr}^{-1}\right)$. However, the different distributions of magnetic chrons have no change in the starting and terminal points of flowline (Fig. 9). The paleogeographic reconstruction provided hints for the paleo-location of the Calamian Islands prior to the opening of the SCS and Paleogene rifting of the northern SCS continental margin. The result is consistent with the areal distribution (western Dongsha-Penghu Uplift), timing of formation (Late Cretaceous), and contractional direction (close to the NW-SE) of the structural inversion. The areal distribution of the Late Mesozoic structural inversion in the study area is $\sim 100 \mathrm{~km}$ (Fig. 7) and may imply that the collider might not be very big. Moreover, the potential collider was the Calamian Islands as suggested by the paleogeographic reconstruction (Fig. 9). This result fits the scenario of collision event from Zamoras and Matsuoka (2004) nicely that

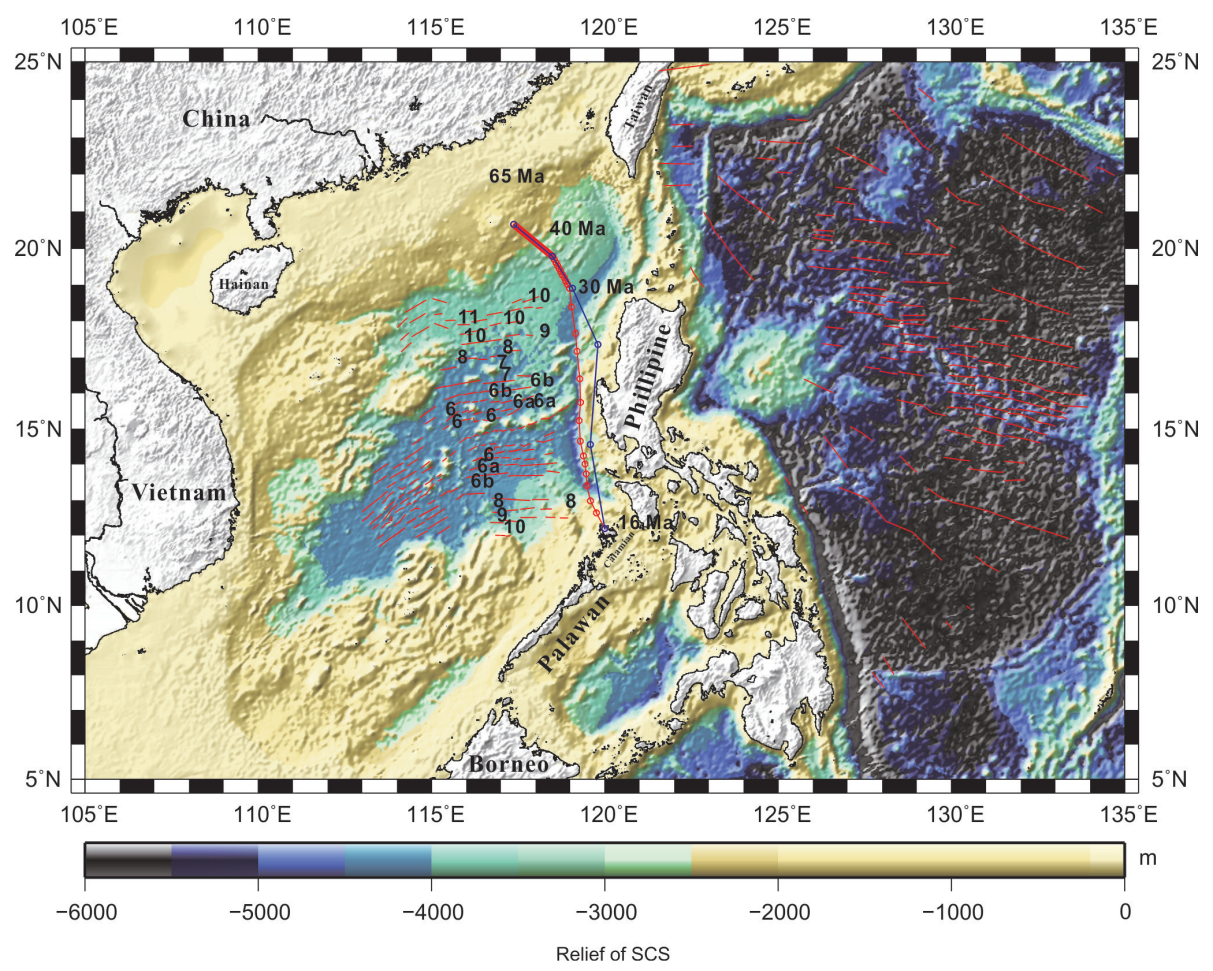

Fig. 9. Two flow-lines of the Palawan blocks calculated at $1 \mathrm{My}$ intervals from 65 - 16 Ma according to Euler poles in the SCS (Briais et al. 1993; Barckhausen and Roeser 2004), linear magnetic anomalies (Briais et al. 1993; Barckhausen and Roeser 2004) with lineation age (Gee and Kent 2007), stretching factor and $\beta$ value (Su et al. 1989), and plate movement direction from a previous study (Zhou et al. 1995) to run plate reconstruction. The lines and circles in red (calculated from Briais et al. 1993) and blue (calculated from Barckhausen and Roeser 2004) are location changes of the Palawan blocks and the drifting trace. The red dashed lines are marine magnetic anomalies from Briais et al. (1993). (Color online only) 
the collider might just be the seamount (volcanic islands) swarm (Calamian Islands). Zamoras and Matsuoka (2004) studied the accretion and post-accretion tectonics of the $\mathrm{Ca}$ lamian Islands, North Palawan block, and the Philippines. They analyzed the sedimentary transitions from outcrops and suggested that the accretion events of these belts along the East Asian accretionary complex began with the Middle Jurassic Northern Busuanga Belt accretion, followed by the Late Jurassic Middle Busuanga Belt accretion and the Early Cretaceous Southern Busuanga Belt accretion. Based on stratigraphic correlation with fossil ages, Zamoras and Matsuoka (2004) suggested that accretion-subduction along the East Asian margin ceased, bringing tectonic stability to the region during the Late Cretaceous. In summary, Zamoras and Matsuoka (2004) suggested that the seamount (volcanic islands) swarm of the SBB (Southern Busuanga Belt), formed in the Late Triassic, collided with the MBB (Middle Busuanga Belt) and the NBB (Northern Busuanga Belt) in the northern SCS continental margin during the Cretaceous. The collision event between seamount (volcanic islands) swarm and continental margin is a common tectonic feature worldwide. The Magellan Basin, for example, shows that the most intense penetrative deformation where the collision of the parautochthonous magmatic arc (swarm of volcanic islands) rifted from the active continental margin during the late Jurassic, completed a highly attenuated Wilson cycle and caused structural reactivation of the basement (Dalziel 1986). In addition, there are many examples of such occurrences in central Iran (Bagheri and Stampfli 2008), the New Hebrides subduction zone (Collot and Fisher 1989), the Mariana and Izu-Bonin trenches (Fryer and Smoot 1985), the Japan Trench and Kuril Trench (Lallemand et al. 1989; Yamazaki and Okamura 1989), and the Java Trench (Masson et al. 1990). Moreover, the proposed collider, Calamian Islands (a part of the North Palawan block), according to the paleogeographic reconstruction of this study is also in accordance with the study results of Faure et al. (1989), Knittel et al. (2010), and Walia et al. (2012). Knittel et al. (2010) and Walia et al. (2012) provided the U-Pb dating results from magmatic arc granite in Mindoro and Palawan Island. The age dates are similar to Taiwan and eastern continental margin and indicate that both Palawan and Mindoro islands are part of the continental margin of South China Sea continental margin during the Mesozoic (Knittel et al. 2010; Walia et al. 2012). Faure et al. (1989) suggested that the North Palawan, Mindoro, Tablas, Romblon, Sibuyan, and Carabao islands are likely continental fragments that rifted from Asia during the Cenozoic.

There is no doubt that a NE-SW subduction zone was located in the northern continental margin of the SCS during Middle Mesozoic (Hilde et al. 1977; Holloway 1982; Taylor and Hayes 1983; Zheng 1985; Letouzey and Sage 1988; Williams et al. 1988; Wang and Li 2009). Nevertheless, the details of the tectonic events that occurred in Mesozoic have been debated (e.g., Late Mesozoic collision event and its colliders). Li (2000) studied A-type granites (from 90 $140 \mathrm{Ma}$ ) in South China and suggested that these were in a rifting tectonic setting. The A- and I-type granite dating results in South China from Dai et al. (1992), Martin et al. (1994), Chen et al. (1996), and Yui et al. (1996) recorded rapid cooling rates that favored an extensional and/or rifting setting. Thus, Li (2000) suggested that the 90 Ma A-type granite (Kuiqi granite) was formed during the initiation of the extension of the northern continental margin of the SCS. In addition, $\mathrm{Li}$ and $\mathrm{Li}$ (2007) also reported post-150 Ma postorogenic magmatism with a coastward-younging trend and that the younger ages of the granitic rocks around the continental margin are about $90 \mathrm{Ma}$. However, Yan et al. (2014) reported the Late Mesozoic compressional folds in the northern margin of the SCS. Furthermore, our study indicates that the structural inversion around the western Dongsha-Penghu Uplift may have been caused by a collision event. According to the previous studies, other collision events have been explained along the SCS continental margin. For the southern part of the northern SCS continental margin, Li et al. (2007), Hall (2012), and Morley (2012) suggested the other collision events and the collider may be the Luconia-Dangerous Grounds micro-continent (Fig. 10). Hall (2009, 2012), Hall et al. (2011), and Morley (2012) suggested that the collider was the Luconia-Dangerous Grounds, and Li et al. (2007) suggested the collider was a docking of micro-continental blocks (including the Palawan blocks, Paracel Islands, Macclesfield Bank, and Reed Bank extending from Indochina to southwestern offshore Taiwan). Faure et al. (1989) suggested a collision of the West Philippines block (including Palawan, Mindoro, Romblon, and Zamboanga areas) with SE Asia occurred around Late Mesozoic. The smallest collider in Late Mesozoic around the northern SCS continental margin is the Palawan blocks as suggested by Zamoras and Matsuoka (2004). In addition to this, Yan et al. (2014) reported the Late Mesozoic compressional folds in the northern margin of the SCS. For the northern part of the northern SCS continental margin, the Peikang basement high (Yuan et al. 1985; Shaw et al. 1990; Chow et al. 1992) and the Nanao orogeny in Taiwan (Ho 1982; Jahn et al. 1986; Lo and Onstott 1995) were generated by contractional event during the Late Mesozoic (90 - 110 Ma; Jahn et al. 1986).

Summarizing the results of this study and the tectonic evolution of the South China continental margin from previous studies (Taylor and Hayes 1980, 1983; Holloway 1982; Briais et al. 1993; Wang and Li 2009; Li et al. 2012), we can graphically illustrate the tectonic scenario of the collision event in the study area (around the western DongshaPenghu Uplift; Fig. 10). In Fig. 10, the paleogeography reconstruction was designed to keep North China Block fixed. During the Late Mesozoic, the collision, due to a subduction zone (Holloway 1982), caused the reactivation of some normal faults to form a series of high-angle reverse faults. 
Paleogeography reconstruction on collision timing ( $~ 90 \mathrm{Ma})$

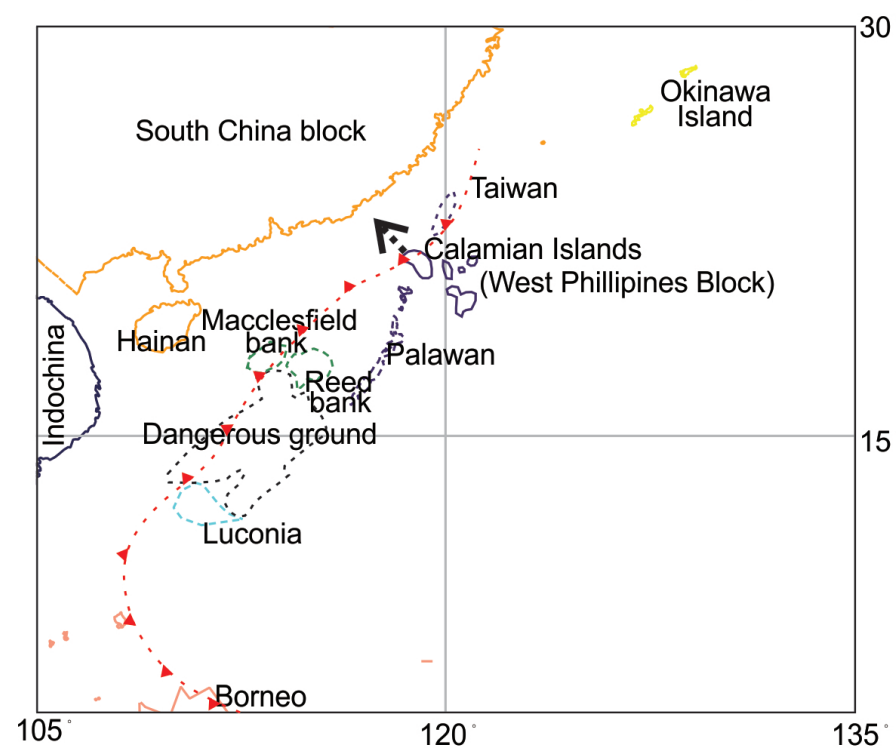

Fig. 10. A cartoon illustrating the paleogeography of the northern SCS continental margin during the Late Cretaceous. The paleogeography reconstructions keep North China Block fixed. Around $90 \mathrm{Ma}$ (Late Cretaceous) might have experienced a collision event along a subduction zone, suggested by Holloway (1982), by the seamount (volcanic islands) swarm (i.e., Calamian Islands) of the northern Palawan blocks (or western Philippines block suggested by Faure et al. 1989) and the northern continental margin of the SCS. It is likely that there were other collision events during the Early to Late Cretaceous, as Li et al. (2007), Morley (2012), and Hall (2012) have suggested, and the collider may be the Luconia-Dangerous Grounds micro-continent (including the Palawan blocks, Paracel Islands, Macclesfield Bank, and Reed Bank extending from Indochina to southwestern offshore Taiwan) shown as the dash line polygons. (Color online only)

These high-angle reverse faults formed the NE-SW trending anticline around the western Dongsha-Penghu Uplift.

\section{CONCLUSIONS}

This study used seismic profiles with detrital zircon $\mathrm{U}-\mathrm{Pb}$ ages and subsurface geological data of the well MZ-1-1 in the western Dongsha-Penghu Uplift, northern SCS continental margin. Because of the continental margin rifting and SCS seafloor spreading from Late Mesozoic to Cenozoic, most areas of the northern SCS continental margin revealed extensional structures. Only in the study area (i.e., western Dongsha-Penghu Uplift) is there structural evidence for contraction. Based on seismic interpretations, we identified the regional high-angle reverse faults which may have been caused by reactivation of pre-existing normal faults. These high-angle reverse faults were caused by structural inversion that took place during the Late Cretaceous based on the age controls from well MZ-1-1. The structural inversion formed an anticline which trends NE-SW with only $\sim 100 \mathrm{~km}$ wide in the western Dongsha-Penghu Uplift. The paleogeographic reconstruction showed that Calamian Islands were located in the structural inversion area of the western Dongsha-Penghu Uplift during the latest Mesozoic and the islands drifted to the present location after the initiation of seafloor spreading. Based on the areal distribution of the regional structural in- version $(\sim 100 \mathrm{~km})$ and the paleogeographic reconstruction, we suggest that the regional structural inversion was formed by the collision between the northern continental margin of the SCS and the seamount (volcanic islands) swarm of the Calamian Islands [or the West Philippines block by Faure et al. (1989); or North Palawan block by Zamoras and Matsuoka (2004)] during the Late Cretaceous. This hypothesis agrees well with the studies of Calamian Islands by Zamoras and Matsuoka (2004). Based on the current evidence, we favour that the collider was only the seamount (volcanic islands) swarm (Calamian Island) along a then active northern SCS continental margin.

Acknowledgements We are grateful to CPC-Taiwan, and TCPOC for granting permission to publish this study. We also thank National Chung Cheng University, Taiwan for the help of detrital zircon dating. We thank the constructive reviewers by Dr. Kenn-Ming Yang, Dr. Anne Briais, and our anonymous reviewer. We acknowledge Dr. J. Gregory Shellnutt carefully proof-read this manuscript.

\section{REFERENCES}

Andersen, T., 2002: Correction of common lead in U-Pb analyses that do not report ${ }^{204} \mathrm{~Pb}$. Chem. Geol., 192, 5979, doi: 10.1016/S0009-2541(02)00195-X. [Link] 
Bagheri, S. and G. M. Stampfli, 2008: The Anarak, Jandaq and Posht-e-Badam metamorphic complexes in central Iran: New geological data, relationships and tectonic implications. Tectonophysics, 451, 123-155, doi: 10.1016/j.tecto.2007.11.047. [Link]

Bailey, C. M., S. Giorgis, and L. Coiner, 2002: Tectonic inversion and basement buttressing: An example from the central Appalachian Blue Ridge province. J. Struct. Geol., 24, 925-936, doi: 10.1016/S01918141(01)00102-X. [Link]

Barckhausen, U. and H. A. Roeser, 2004: Seafloor spreading anomalies in the South China Sea revisited. In: Clift, P., W. Kuhnt, P. wang, and D. E. Hayes (Eds.), Continent-Ocean Interactions within East Asian Marginal Seas, Geophysical Monograph Series, American Geophysical Union, 121-125, doi: 10.1029/GM149. [Link]

Barr, S. M. and A. S. MacDonald, 1981: Geochemistry and geochronology of late Cenozoic basalts of Southeast Asia: Summary. Geol. Soc. Am. Bull., 92, 508-512, doi: 10.1130/0016-7606(1981)92<508:GAGOLC >2.0 .CO;2. [Link]

Bowring, S. A., B. Schoene, J. L. Crowley, J. Ramezani, and D. J. Condon, 2006: High-precision U-Pb zircon geochronology and the stratigraphic record: progress and promise. In: Olszewski, T. D., W. D. Huff, and S. H. Butts (Eds.), Geochronology: Emerging Opportunities, Paleontological Society Papers, Vol. 12, Philadelphia, Pennsylvania, 25-46.

Briais, A., P. Patriat, and P. Tapponnier, 1993: Updated interpretation of magnetic anomalies and seafloor spreading stages in the South China Sea: Implications for the Tertiary tectonics of Southeast Asia. J. Geophys. Res., 98, 6299-6328, doi: 10.1029/92JB02280. [Link]

Chen, C. H., C. Y. Lee, and R. Shinjo, 2008: Was there Jurassic paleo-Pacific subduction in South China? Constraints from ${ }^{40} \mathrm{Ar} /{ }^{39} \mathrm{Ar}$ dating, elemental and $\mathrm{Sr}-\mathrm{Nd}-\mathrm{Pb}$ isotopic geochemistry of the Mesozoic basalts. Lithos, 106, 83-92, doi: 10.1016/j.lithos.2008.06.009. [Link]

Chen, C. H., P. S. Hsieh, K. L. Wang, H. J. Yang, W. Lin, Y. H. Liang, C. Y. Lee, and H. C. Yang, 2010: Zircon LAICPMS U-Pb ages and Hf isotopes of Huayu (Penghu Islands) volcanics in the Taiwan Strait and tectonic implication. J. Asian Earth Sci., 37, 17-30, doi: 10.1016/j. jseaes .2009.07.003. [Link]

Chen, W. S., H. C. Yang, and C. H. Lo, 1996: Tectonic evolution and uplifting history of the Pingtan-Dungshan metamorphic; belt at the coast of Fujian Province. Annual Meeting of the Geological Society of China, 534538. (in Chinese)

Chow, D. J., T. Y. Chang, S. C. Liang, and H. C. Sheen, 1992: Geophysical Study on Pre-Miocene Hydrocarbon Traps Around the Peikang Area. Petrol. Geol. Taiwan, 27, 153-175.
Chung, S. L., S. S. Sun, K. Tu, C. H. Chen, and C. Y. Lee, 1994: Late Cenozoic basaltic volcanism around the Taiwan Strait, SE China: Product of lithosphere-asthenosphere interaction during continental extension. Chem. Geol., 112, 1-20, doi: 10.1016/0009-2541(94)90101-5. [Link]

Clift, P. and J. Lin, 2001: Preferential mantle lithospheric extension under the South China margin. Mar. Petrol. Geol., 18, 929-945, doi: 10.1016/s02648172(01)00037-x. [Link]

Collot, J. Y. and M. A. Fisher, 1989: Formation of forearc basins by collision between seamounts and accretionary wedges: An example from the New Hebrides subduction zone. Geology, 17, 930-933, doi: 10.1130/009 1-7613(1989)017<0930:FOFBBC>2.3.CO;2. [Link]

Dai, T., L. Zhenghua, X. Jingrong, P. Zhiping, Q. Huaning, and $\mathrm{H}$. Zhenduo, 1992: ${ }^{40} \mathrm{Ar} /{ }^{39} \mathrm{Ar}$ plateau age spectra of feldspars and their geological implications. Chin. J. Geochem., 11, 193-200, doi: 10.1007/BF02842264. [Link]

Dalziel,I. W. D., 1986: Collision and Cordilleran orogenesis: an Andean perspective. Geol. Soc. Lond. Spec. Publ., 19, 389-404, doi: 10.1144/GSL.SP.1986.019.01.22. [Link]

Davis, G. H., S. J. Reynolds, and C. F. Kluth, 2012: Structural Geology of Rocks and Regions ( $3^{\text {rd }}$ Ed.), Wiley, Hoboken, 864 pp.

Dong, D. D., S. G. Wu, G. C. Zhang, and S. Q. Yuan, 2008: Rifting process and formation mechanisms of syn-rifting stage prolongation in the deepwater basin, northern South China Sea. Chin. Sci. Bull., 53, 3715-3725, doi: 10.1007/s1 1434-008-0326-1. [Link]

Dong, D. D., G. C. Zhang, K. Zhong, S. Q. Yuan, and S. G. Wu, 2009: Tectonic evolution and dynamics of deepwater area of Pearl River Mouth basin, northern South China Sea. J. Earth Sci., 20, 147-159, doi: 10.1007/ s12583-009-0016-1. [Link]

Falvey, D. A., 1974: The development of continental margins in plate tectonic theory. APEA, 14, 95-106.

Faure, M., Y. Marchadier, and C. Rangin, 1989: Pre-Eocene Synmetamorphic Structure in the Mindoro-RomblonPalawan Area, West Philippines, and implications for the history of southeast Asia. Tectonics, 8, 963-979, doi: 10.1029/TC008i005p00963. [Link]

Feng, Z. and W. Zhang, 1982: Tectonic evolution of Zhujiangkou (Pearl-River-Mouth) basin and origin of South China Sea. Acta Geoil. Sin., 55, 212-222. (in Chinese)

Feng, Z., W. Miao, W. Zheng, and S. Chen, 1992: Structure and hydrocarbon potential of the para-passive continental margin of the northern South China Sea. In: Watkins, J. S., Z. Feng, and K. J. McMillen (Eds.), Geology and Geophysics of Continental Margins, AAPG, Tulsa, 27-41.

Fryer, P. and N. C. Smoot, 1985: Processes of seamount 
subduction in the Mariana and Izu-Bonin trenches. Mar. Geol., 64, 77-90, doi: 10.1016/0025-3227(85)90161-6. [Link]

Gee, J. S. and D. V. Kent, 2007: Source of oceanic magnetic anomalies and the geomagnetic polarity timescale. In: Kono, M. (Ed.), Treatise on Geophysics, Vol. 5, Elsevier, 455-507, doi: 10.1016/B978-0444527486.00097-3. [Link]

Gehrels, G., V. Valencia, and A. Pullen, 2006: Detrital zircon geochronology by laser ablation multicollector ICPMS at the Arizona LaserChron center. In: Olszewski, T. (Ed.), Geochronology: Emerging Opportunities, Paleontology Society Papers, Vol. 12, 67-76.

Gradstein, F. M., J. G. Ogg, M. D. Schmitz, and G. M. Ogg, 2012: The Geologic Time Scale 2012, Elsevier, $1176 \mathrm{pp}$.

Guong, Z., Q. Jin, Z. Qin, S. Wang, and J. Meng, 1989: Geology, tectonic, and evolution of the Pearl River Mouth Basin. In: Zhu, X. (Ed.), Chinese Sedimentary Basins, Elsevier, 181-196.

Hall, R., 2009: Southeast Asia's changing palaeogeography. Blum.-Biodivers. Evol. Biogeogr. Plants, 54, 148-161, doi: 10.3767/000651909X475941. [Link]

Hall, R., 2012: Late Jurassic-Cenozoic reconstructions of the Indonesian region and the Indian Ocean. Tectonophysics, 570, 1-41, doi: 10.1016/j.tecto.2012.04.021. [Link]

Hall, R., M. A. Cottam, and M. E. J. Wilson, 2011: The SE Asian gateway: history and tectonics of the AustraliaAsia collision. Geol. Soc. Lond. Spec. Publ., 355, 1-6, doi: 10.1144/SP355.1. [Link]

Hao, H., H. Lin, M. Yang, H. Xue, and J. Chen, 2001: The Mesozoic in Chaoshan Depression: A new domain of petroleum exploration. China Offshore Oil Gas Geol., 15, 157-163. (in Chinese)

Hao, H. J., H. S. Shi, X. T. Zhang, T. C. Jiang, and S. L. Tang, 2009: Mesozoic sediments and their petroleum geology conditions in Chaoshan sag: A discussion based on drilling results from the exploratory well LF35-1-1. China Offshore Oil Gas Geol., 21, 151-156. (in Chinese)

Haq, B. L., J. Hardenbol, and P. R. Vail, 1987: Chronology of fluctuating sea level since the Triassic. Science, 235, 1156-1167, doi: 10.1126/science.235.4793.1156. [Link]

Hilde, T. W. C., S. Uyeda, and L. Kroenke, 1977: Evolution of the western Pacific and its margin. Tectonophysics, 38, 145-165, doi: 10.1016/0040-1951(77)90205-0. [Link]

Ho, C. S., 1982: Tectonic evolution of Taiwan: Explanation text of the tectonic map of Taiwan, Ministry of Economic Affairs, Republic of China.

Holloway, N. H., 1982: North Palawan block, Philip- pines-its relation to Asian mainland and role in evolution of South China Sea. AAPG Bulletin, 66, 1355-1383, doi: 10.1306/03B5A7A5-16D1-11D78645000102C1865D. [Link]

Huang, S. T., K. M. Yang, J. H. Hung, J. C. Wu, H. H. Ting, W. W. Mei, S. H. Hsu, and M. Lee, 2004: Deformation Front Development at the Northeast Margin of the Tainan Basin, Tainan-Kaohsiung Area, Taiwan. Mar. Geophys. Res., 25, 139-156, doi: 10.1007/s11001-0050739-z. [Link]

Jahn, B. M., F. Martineau, J. J. Peucat, and J. Cornichet, 1986: Geochronology of the Tananao schist complex, Taiwan, and its regional tectonic significance. Tectonophysics, 123, 103-124, doi: 10.1016/00401951(86)90009-0. [Link]

Jin, Q., W. Zeng, S. Zhong, and Z. Wu, 1984: Analysis on petroleum geological conditions of the Pearl River Mouth basin. Acta Geoil. Sin., 58, 324-336. (in Chinese)

Knittel, U., C. H. Hung, T. F. Yang, and Y. Iizuka, 2010: Permian arc magmatism in Mindoro, the Philippines: An early Indosinian event in the Palawan Continental Terrane. Tectonophysics, 493, 113-117, doi: 10.1016/j. tecto.2010.07.007. [Link]

Lallemand, S., R. Culotta, and R. V. Huene, 1989: Subduction of the Daiichi Kashima Seamount in the Japan Trench. Tectonophysics, 160, 231-247, doi: 10.1016/0040-1951(89)90393-4. [Link]

Lan, C. Y., T. Usuki, K. L. Wang, T. F. Yui, K. Okamoto, Y. H. Lee, T. Hirata, Y. Kon, Y. Orihashi, J. G. Liou, and C. S. Lee, 2009: Detrital zircon evidence for the antiquity of Taiwan. Geosci. J., 13, 233-243, doi: 10.1007/ s12303-009-0023-3. [Link]

Lee, T. Y., C. H. Tang, J. S. Ting, and Y. Y. Hsu, 1993: Sequence stratigraphy of the Tainan Basin, offshore southwestern Taiwan. Petrol. Geo. Taiwan, 28, 119-158.

Lee, T. Y., C. H. Lo, S. L. Chung, C. Y. Chen, P. L. Wang, W. P. Lin, H. Nguyen, T. C. Cung, and T. Y. Nguyen, 1998: ${ }^{40} \mathrm{Ar} r{ }^{39} \mathrm{Ar}$ dating result of Neogene basalts in Vietnam and its tectonic implication. In: Flower, M. F. J., S. L. Chung, C. H. Lo, and T. Y. Lee (Eds.), Mantle Dynamics and Plate Interaction in East Asia, American Geophysical Union, 317-330, doi: 10.1029/ GD027p0317. [Link]

Letouzey, J. and L. Sage, 1988: Geological and Structural Map of Eastern Asia, AAPG, Tulsa.

Li, C. F., Z. Y. Zhou, J. B. Li, H. Hao, and J. H. Geng, 2007: Structures of the northeasternmost South China Sea continental margin and ocean basin: Geophysical constraints and tectonic implications. Mar. Geophys. Res., 28, 59-79, doi: 10.1007/s1 1001-007-9014-9. [Link]

Li, C. F., Z. Zhou, H. Hao, H. Chen, J. Wang, B. Chen, and 
J. Wu, 2008: Late Mesozoic tectonic structure and evolution along the present-day northeastern South China Sea continental margin. J. Asian Earth Sci., 31, 546561, doi: 10.1016/j.jseaes.2007.09.004. [Link]

Li, X.H., 2000: Cretaceous magmatism and lithospheric extension in Southeast China. J. Asian Earth Sci., 18, 293 305, doi: 10.1016/S1367-9120(99)00060-7. [Link]

Li, Z., Y. Xu, T. Hao, Y. Xu, and J. Liu, 2009: P wave velocity structure in the crust and upper mantle beneath northeastern South China Sea and surrounding regions. Earth Sci. Front., 16, 252-260, doi: 10.1016/S18725791(08)60085-8. [Link]

Li, Z. W., 1984: A discussion on the crustal nature of the central and northern parts of South China Sea. Acta Geophys. Sin., 27, 153-166. (in Chinese)

Li, Z. X., X. H. Li, S. L. Chung, C. H. Lo, X. S. Xu, and W. X. Li, 2012: Magmatic switch-on and switch-off along the South China continental margin since the Permian: Transition from an Andean-type to a Western Pacifictype plate boundary. Tectonophysics, 532, 271-290, doi: 10.1016/j.tecto.2012.02.011. [Link]

Li, Z. X. and X. H. Li, 2007: Formation of the 1300-kmwide intracontinental orogen and postorogenic magmatic province in Mesozoic South China: A flat-slab subduction model. Geology, 35, 179-182, doi: 10.1130/ G23193A.1. [Link]

Lin, A. T., A. B. Watts, and S. P. Hesselbo, 2003: Cenozoic stratigraphy and subsidence history of the South China Sea margin in the Taiwan region. Basin Res., 15, 453478, doi: 10.1046/j.1365-2117.2003.00215.x. [Link]

Lo, C. H., 2004: Service report of isotopic dating and chemical analysis about well MZ-1-1. Internal Report, Tainan-Chaoshan Petroleum Operating Company and Geological Society of Taiwan, Taiwan.

Lo, C. H. and T. C. Onstott, 1995: Rejuvenation of KAr systems for minerals in the Taiwan Mountain Belt. Earth Planet. Sci. Lett., 131, 71-98, doi: 10.1016/0012-821X(95)00011-Z. [Link]

Lüdmann, T. and H. K. Wong, 1999: Neotectonic regime on the passive continental margin of the northern South China Sea. Tectonophysics, 311, 113-138, doi: 10.1016/S0040-1951(99)00155-9. [Link]

Martin, H., B. Bonin, R. Capdevila, B. M. Jahn, J. Lameyre, and Y. Wang, 1994: The Kuiqi Peralkaline Granitic Complex (SE China): Petrology and Geochemistry. $J$. Petrol.,35,983-1015, doi: 10.1093/petrology/35.4.983. [Link]

Masson, D. G., L. M. Parson, J. Milsom, G. Nichols, N. Sikumbang, B. Dwiyanto, and H. Kallagher, 1990: Subduction of seamounts at the Java Trench: A view with long-range sidescan sonar. Tectonophysics, 185, 51-65, doi: 10.1016/0040-1951(90)90404-V. [Link]

Morley, C. K., 2012: Late Cretaceous-Early Palaeogene tec- tonic development of SE Asia. Earth-Sci. Rev., 115, 37-75, doi: 10.1016/j.earscirev.2012.08.002. [Link]

Nguyen, H., M. F. J. Flower, and R. W. Carlson, 1996: Major, trace element, and isotopic compositions of Vietnamese basalts: Interaction of hydrous EM1-rich asthenosphere with thinned Eurasian lithosphere. Geochim. Cosmochim. Acta, 60, 4329-4351, doi: 10.1016/ S0016-7037(96)00247-5. [Link]

Orihashi, Y., S. I. Nakai, and T. Hirata, 2008: U-Pb Age Determination for Seven Standard Zircons using Inductively Coupled Plasma-Mass Spectrometry Coupled with Frequency Quintupled Nd-YAG $(\lambda=213 \mathrm{~nm})$ Laser Ablation System: Comparison with LA-ICP-MS Zircon Analyses with a NIST Glass Reference Material. Resour. Geol., 58, 101-123, doi: 10.1111/j.17513928.2008.00052.x. [Link]

Pang, X., C. M. Chen, H. S. Shi, Y. Shu, L. Shao, M. He, and J. Shen, 2005: Response between relative sea level change and the Pearl River deep-water fan system in the South China Sea. Earth Sci. Front., 12, 167-177. (in Chinese)

Ru, K. and J. D. Pigott, 1986: Episodic rifting and subsidence in the South China Sea. AAPG Bull., 70, 1136-1155, doi: 10.1306/94886a8d-1704-11d78645000102c1865d. [Link]

Sangree, J. B. and J. M. Widmier, 1978: Seismic stratigraphy and global changes of sea level, part 9: seismic interpretation of clastic depositional facies. $A A P G, \mathbf{6 2}$, 752-771.

Shaw, C. L., C. W. Lee, W. R. Chi, and T. Y. Chiou, 1990: Stratigraphy and sedimentation of the tertiary basin of Western Taiwan. Bull. Explor. Produc. Res., 13, 73-90.

Shi, H. and C. F. Li, 2012: Mesozoic and early Cenozoic tectonic convergence-to-rifting transition prior to opening of the South China Sea. Int. Geol.Rev., 54, 1801-1828, doi: 10.1080/00206814.2012.677136. [Link]

Shi, X.,E. Burov, S. Leroy, X. Qiu, and B. Xia, 2005: Intrusion and its implication for subsidence: A case from the Baiyun Sag, on the northern margin of the South China Sea. Tectonophysics, 407, 117-134, doi: 10.1016/j. tecto.2005.07.004. [Link]

Su, D., N. White, and D. McKenzie, 1989: Extension and subsidence of the Pearl River Mouth Basin, northern South China Sea. Basin Res., 2, 205-222, doi: 10.1111/ j.1365-2117.1989.tb00036.x. [Link]

Taylor, B. and D. E. Hayes, 1980: The tectonic evolution of the South China Basin. In: Hayes, D. E. (Ed.), The Tectonic and Geologic Evolution of Southeast Asian Seas and Islands, Part 1, American Geophysical Union, Washington, D.C., 89-104, doi: 10.1029/GM023p0089. [Link]

Taylor, B. and D. E. Hayes, 1983: Origin and history of the 
South China Sea Basin. In: Hayes, D. E. (Ed.), The Tectonic and Geologic Evolution of Southeast Asian Seas and Islands, Part 2, American Geophysical Union, Washington, D.C., 23-56, doi: 10.1029/GM027p0023. [Link]

Tzeng, J., 1994: Tertiary Seismic Stratigraphic Analysis of the Tainan Basin, National Taiwan University, 102 pp. (in Chinese)

Vail, P. R., 1987: Part 1: Seismic stratigraphy interpretation procedure. In: Bally, A. W. (Ed.), Atlas of Seismic Stratigraphy, Vol. 1, AAPG Studies in Geology, No. 27, Tulsa, 1-14.

Vail, P. R. and W. W. Wornardt, 1991: An integrated approach to exploration and development in the 90s: Well log-seismic stratigraphy analysis. Trans.-Gulf Coast Assoc. Geol. Soc., 41, 630-650.

Walia, M., U. Knittel, S. Suzuki, S. L. Chung, R. E. Pena, and T. F. Yang, 2012: No Paleozoic metamorphics in Palawan (the Philippines)? Evidence from single grain U-Pb dating of detrital zircons. J. Asian Earth Sci., 52, 134-145, doi: 10.1016/j.jseaes.2012.03.005. [Link]

Wang, C. and Y. Sun, 1994: Development of paleogene depressions and deposition of lacustrine source rocks in the pearl river mouth basin, northern margin of the south china sea. AAPG Bulletin, 78, 1711-1728.

Wang, J., B. Chen, J. Wu, H. Zhong, H. Hao, and P. Li, 2003: Integrated geophysical studies on the basement structure and the Mesozoic strata in the Chaoshan Depression. In: Li, J. and S. Gao (Eds.), Lithospheric Structure and Dynamics of the Chinese Marginal Seas, Vol. 2, Serial Studies of the Formation and Evolution of the Chinese Marginal Seas, Ocean Press, Beijing, 53-62. (in Chinese)

Wang, P. and Q. Li, 2009: The South China Sea, Developments in Paleoenvironmental Research, Springer Netherlands, 25-73, doi: 10.1007/978-1-4020-9745-4. [Link]

Williams, P. R., C. R. Johnston, R. A. Almond, and W. H. Simamora, 1988: Late Cretaceous to Early Tertiary structural elements of West Kalimantan. Tectonophysics, 148, 279-297, doi: 10.1016/0040-1951(88)901357. [Link]

Wu, J. M., 1988: Cenozoic basins of the South China Sea. Episodes, 11, 91-96.

Yamazaki, T. and Y. Okamura, 1989: Subducting seamounts and deformation of overriding forearc wedges around Japan. Tectonophysics, 160, 207-229, doi: 10.1016/0040-1951(89)90392-2. [Link]

Yan, P. and H. Liu, 2004: Tectonic-stratigraphic division and blind fold structures in Nansha Waters, South China Sea. J. Asian Earth Sci., 24, 337-348, doi: 10.1016/j. jseaes.2003.12.005. [Link]
Yan, P., L. Wang, and Y. Wang, 2014: Late Mesozoic compressional folds in Dongsha Waters, the northern margin of the South China Sea. Tectonophysics, 615-616, 213-223, doi: 10.1016/j.tecto.2014.01.009. [Link]

Yang, S., Z. Tong, Q. He, and J. Hao, 2008: Mesozoic hydrocarbon generation history and igneous intrusion impacts in Chaoshan depression, South China sea: A case of LF35-1-1 well. China Offshore Oil Gas Geol., 20, 152-156. (in Chinese)

Yu, H. S., 1994: Structure, stratigraphy and basin subsidence of Tertiary basins along the Chinese southeastern continental margin. Tectonophysics, 235, 63-76, doi: 10.1016/0040-1951(94)90017-5. [Link]

Yuan, J., S. J.Lin, S. T. Huang, and C. L. Show, 1985: Stratigraphic study on the pre-Miocene under the Peikang area, Taiwan. Petrol. Geol. Taiwan, 21, 115-127.

Yui, T. F., L. Heaman, and C. Y. Lan, 1996: U-Pb and Sr isotopic studies on granitoids from Taiwan and ChinmenLieyu and tectonic implications. Tectonophysics, 263, 61-76, doi: 10.1016/S0040-1951(96)00023-6. [Link]

Zamoras, L. R. and A. Matsuoka, 2004: Accretion and postaccretion tectonics of the Calamian Islands, North Palawan block, Philippines. Island Arc, 13, 506-519, doi: 10.1111/j.1440-1738.2004.00443.x. [Link]

Zheng, X., 1985: Meso-Cenozoic volcanic rocks in East China and adjacent areas with relation to plate tectonics. Tectonophysics, 112, 533-550, doi: 10.1016/00401951(85)90194-5. [Link]

Zhou, D., K. Ru, and H. Z. Chen, 1995: Kinematics of Cenozoic extension on the South China Sea continental margin and its implications for the tectonic evolution of the region. Tectonophysics, 251, 161-177, doi: 10.1016/0040-1951(95)00018-6. [Link]

Zhou, D., W. Wang, J. Wang, X. Pang, D. Cai, and Z. Sun, 2006: Mesozoic subduction-accretion zone in northeastern south china sea inferred from geophysical interpretations. Sci. China Ser. D, 49, 471-482, doi: 10.1007/s11430-006-0471-9. [Link]

Zhou, D., Z. Sun, H. Z. Chen, H. H. Xu, W. Y. Wang, X. Pang, D. S. Cai, and D. K. Hu, 2008: Mesozoic paleogeography and tectonic evolution of South China Sea and adjacent areas in the context of Tethyan and PaleoPacific interconnections. Island Arc, 17, 186-207, doi: 10.1111/j.1440-1738.2008.00611.x. [Link]

Zhu, J., X. Qiu, H. Kopp, X. Xu, Z. Sun, A. Ruan, J. Sun, and X. Wei, 2012: Shallow anatomy of a continent ocean transition zone in the northern South China Sea from multichannel seismic data. Tectonophysics, 554557, 18-29, doi: 10.1016/j.tecto.2012.05.027. [Link]

Zhu, W., M. Li, and P. Wu, 1999: Petroleum systems of the Zhu III subbasin, Pearl River Mouth Basin, South China Sea. AAPG Bull., 83, 990-1003. 


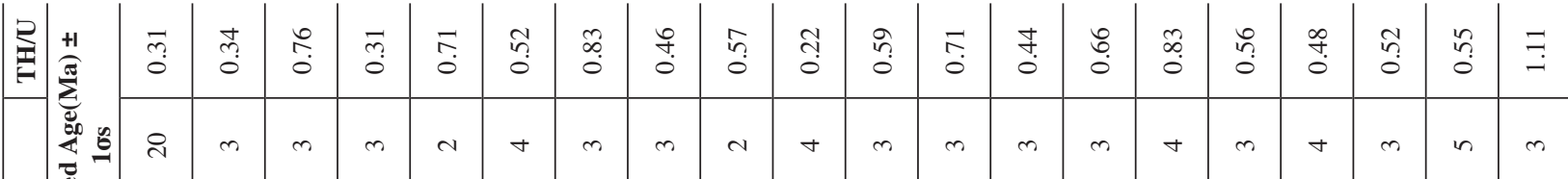

氡

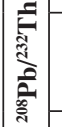

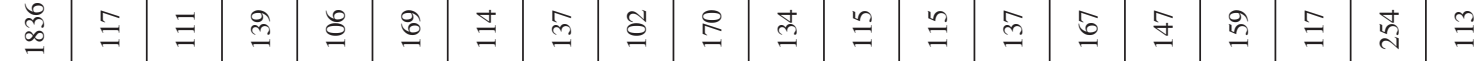

\begin{tabular}{|c|c|c|c|c|c|c|c|c|c|c|c|c|c|c|c|c|c|c|c|c|c|}
\hline 2 & 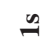 & mे & m & $m$ & $m$ & $\sim$ & $\nabla$ & $m$ & $m$ & $\sim$ & 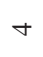 & m & m & $m$ & $m$ & $\nabla$ & $m$ & $\nabla$ & n & in & m \\
\hline & & $\stackrel{t}{\Xi}$ & $\Xi$ & $\Xi$ & ले & 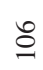 & $\stackrel{\vec{b}}{ }$ & $\stackrel{\Xi}{\Xi}$ & $\hat{m}$ & ฮै & $=$ & $\stackrel{\Xi}{\sim}$ & $\stackrel{n}{=}$ & $\stackrel{n}{=}$ & $\hat{g}$ & $\underline{6}$ & 卞 & ڤे & $\Xi$ & 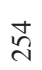 & $\stackrel{M}{=}$ \\
\hline
\end{tabular}

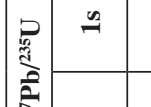

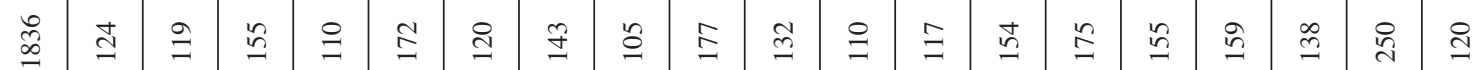

\begin{tabular}{|c|c|c|c|c|c|c|c|c|c|c|c|c|c|c|c|c|c|c|c|c|c|}
\hline क्षे & 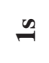 & $\stackrel{\infty}{=}$ & $\Varangle$ & $F$ & $\stackrel{\beth}{\sim}$ & $\hat{\imath}$ & $q$ & $m$ & $\hat{\lambda}$ & $\hat{\imath}$ & ल & $\stackrel{\varrho}{ }$ & 骂 & ల & $\stackrel{\infty}{\sim}$ & ஓ & $\underset{\sim}{\infty}$ & $\tilde{\cong}$ & $\vec{n}$ & $\Xi$ & $m$ \\
\hline हे & & ふু & $\stackrel{\gtrless}{\sim}$ & ลे & $\underset{\exists}{\exists}$ & ટ્స & \pm & $\underset{d}{*}$ & 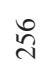 & 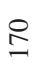 & $\stackrel{\bullet}{\sim}$ & à & $m$ & $\sqrt{n}$ & $\stackrel{+}{+}$ & $\begin{array}{c}\hat{\infty} \\
\text { i }\end{array}$ & $\stackrel{\curvearrowright}{\grave{\lambda}}$ & $\stackrel{\infty}{n}$ & $\stackrel{0}{n}$ & $\overrightarrow{\vec{N}}$ & $i$ \\
\hline
\end{tabular}

\begin{tabular}{|c|c|c|c|c|c|c|c|c|c|c|c|c|c|c|c|c|c|c|c|c|c|}
\hline \multirow{2}{*}{ 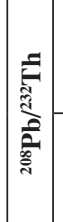 } & $\cong$ & $\begin{array}{l}\text { ते } \\
\text { రి } \\
\text {. }\end{array}$ & $\begin{array}{l}\text { पे } \\
\text { ठุ. } \\
\text {. }\end{array}$ & $\begin{array}{l}0 \\
8 \\
8 \\
0 \\
0\end{array}$ & $\begin{array}{l}\text { ते } \\
\text { ठे } \\
\stackrel{0}{0}\end{array}$ & $\begin{array}{l}\frac{n}{8} \\
\stackrel{8}{0} \\
0\end{array}$ & $\begin{array}{l}\infty \\
\stackrel{\tilde{\delta}}{0} \\
\stackrel{0}{0}\end{array}$ & 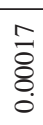 & $\begin{array}{l}\vec{\delta} \\
\stackrel{\delta}{0}\end{array}$ & $\begin{array}{l}\frac{n}{8} \\
\frac{8}{0} \\
0\end{array}$ & $\begin{array}{l}\text { से } \\
\stackrel{0}{0} \\
\stackrel{0}{0}\end{array}$ & $\begin{array}{l}\frac{n}{a} \\
\stackrel{8}{0} \\
\stackrel{0}{0}\end{array}$ & 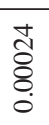 & $\begin{array}{l}\bar{\Xi} \\
\stackrel{8}{0} \\
\dot{0}\end{array}$ & 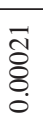 & 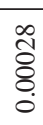 & 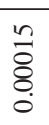 & $\frac{2}{8}$ & 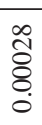 & 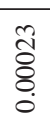 & $\frac{\infty}{8}$ \\
\hline & & $\begin{array}{l}\text { J } \\
\stackrel{0}{0} \\
\stackrel{0}{0}\end{array}$ & $\begin{array}{l}\tilde{D} \\
\infty \\
o \\
0 \\
0\end{array}$ & $\begin{array}{l}n \\
\hat{n} \\
\delta \\
0\end{array}$ & $\begin{array}{l}\mathscr{D} \\
\infty \\
\& \\
0 \\
0\end{array}$ & 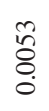 & 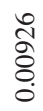 & 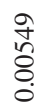 & $\begin{array}{l}\overrightarrow{0} \\
\dot{0} \\
\dot{0}\end{array}$ & $\begin{array}{l}\frac{n}{n} \\
\frac{0}{0} \\
0\end{array}$ & 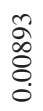 & 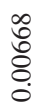 & $\begin{array}{l}\hat{\hat{n}} \\
\hat{\tilde{z}} \\
0 \\
0\end{array}$ & $\begin{array}{l}\text { t } \\
0 \\
0 \\
0\end{array}$ & 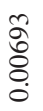 & $\begin{array}{l}\text { Oे } \\
\text { \&े } \\
0 \\
0\end{array}$ & 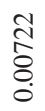 & $\begin{array}{l}\stackrel{\hat{\sigma}}{0} \\
\stackrel{0}{0}\end{array}$ & $\begin{array}{l}\text { t) } \\
\text { ¿े } \\
0\end{array}$ & 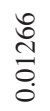 & $\begin{array}{l}\infty \\
\infty \\
0 \\
0\end{array}$ \\
\hline
\end{tabular}

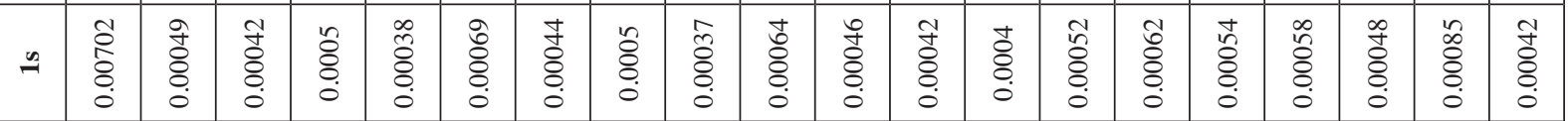




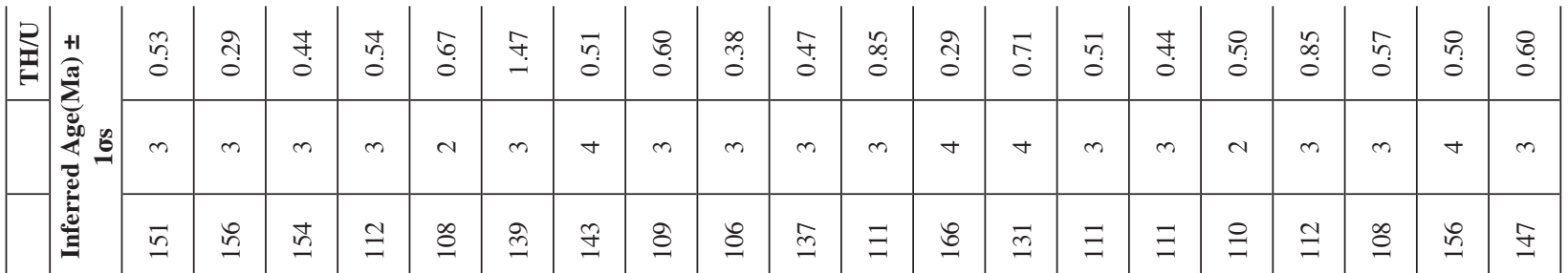

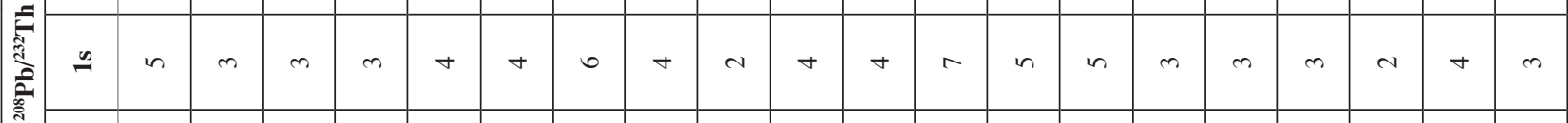

占

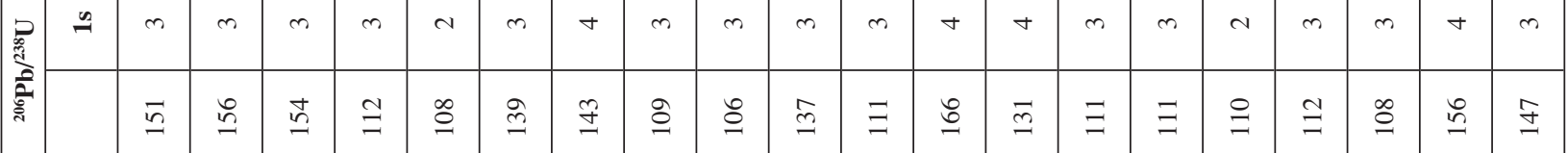
党

\begin{tabular}{|c|c|c|c|c|c|c|c|c|c|c|c|c|c|c|c|c|c|c|}
\hline+ & $r$ & $a$ & $m$ & $m$ & 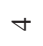 & 0 & $m$ & $a$ & 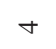 & + & 0 & $r$ & $n$ & $m$ & $m$ & $m$ & $r$ & 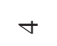 \\
\hline$\tilde{n}$ & $\tilde{n}$ & $\tilde{n}$ & $\stackrel{M}{=}$ & $\stackrel{0}{=}$ & g & $\stackrel{8}{n}$ & $\cong$ & $\widehat{\beth}$ & $\Xi$ & $\bar{m}$ & $\stackrel{ \pm}{I}$ & in & $\stackrel{\infty}{=}$ & $\stackrel{n}{=}$ & $\vec{I}$ & $\Xi$ & $\stackrel{\infty}{\cong}$ & $\stackrel{\infty}{n}$ \\
\hline
\end{tabular}

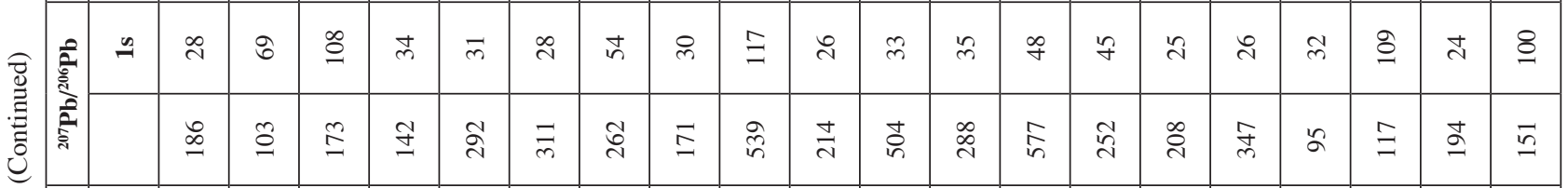

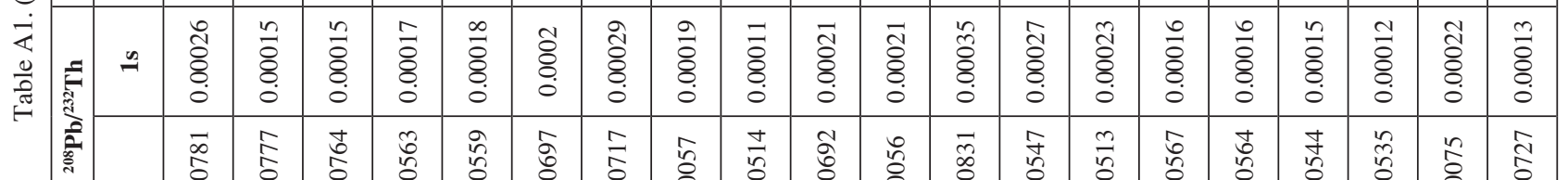

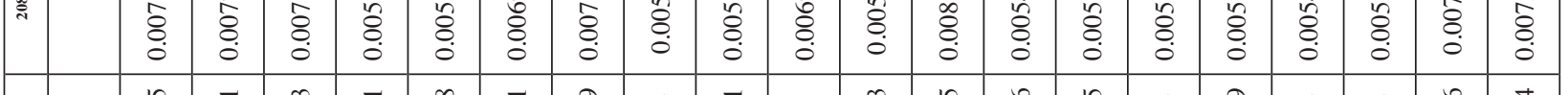

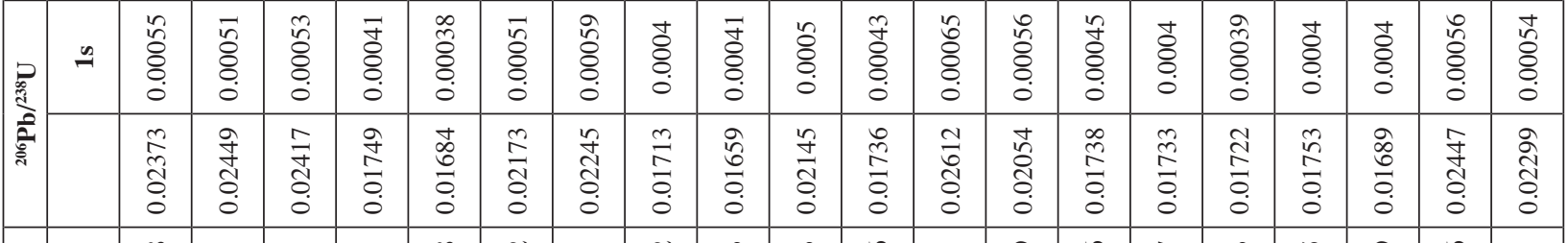

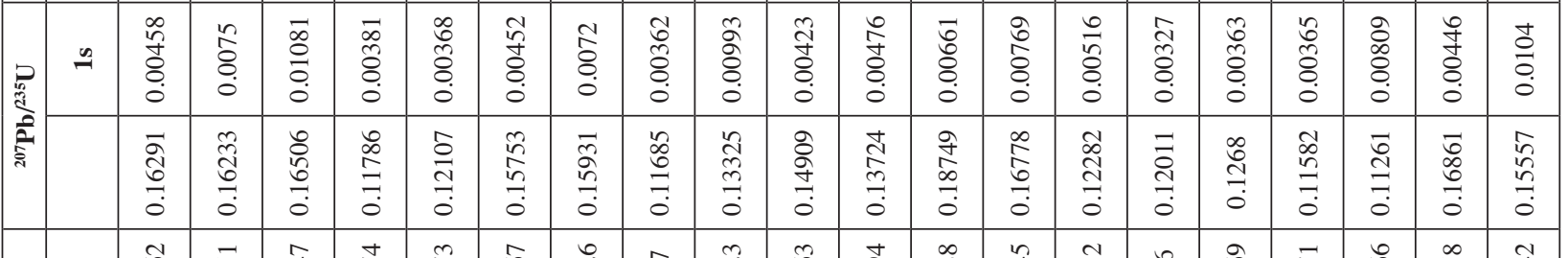

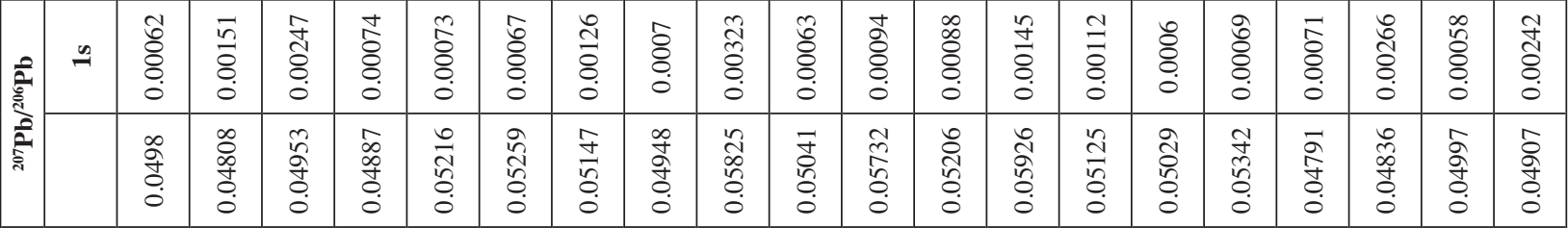

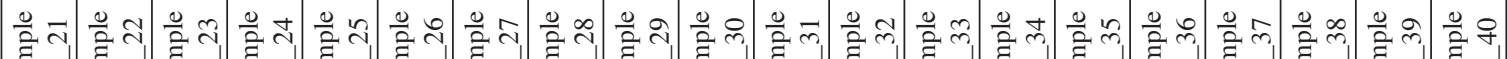

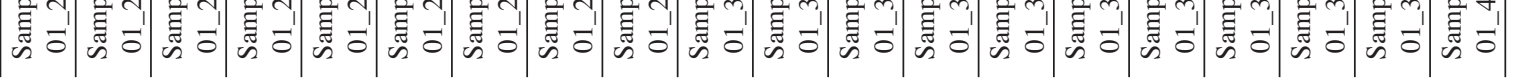


\begin{tabular}{|l} 
\\
\hline
\end{tabular}

\begin{tabular}{|c|c|c|c|c|c|c|c|c|c|c|c|c|c|c|c|c|c|c|c|}
\hline \multirow{3}{*}{ 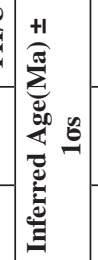 } & $\stackrel{\infty}{0}$ & $\overrightarrow{0}$ & $\stackrel{\text { If }}{0}$ & $\stackrel{0}{+}$ & $\tilde{n}$ & ల్రి & $\stackrel{\infty}{\stackrel{\infty}{0}}$ & $\stackrel{f}{*}$ & $\stackrel{\circ}{\circ}$ & $\bar{n}$ & $\vec{n}$ & $\overline{\tilde{o}}$ & $\stackrel{f}{0}$ & 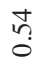 & : & f. & ñ & $\stackrel{0}{\stackrel{0}{0}}$ & $\begin{array}{l}\infty \\
\infty \\
0\end{array}$ \\
\hline & t & $m$ & $m$ & $m$ & $N$ & 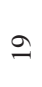 & 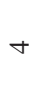 & t & สิ & ナ & t & ¿ి & in & ナ & $m$ & in & $\sigma$ & $\nabla$ & $\nabla$ \\
\hline & $\hat{\jmath}$ & $\stackrel{\bullet}{=}$ & $\tilde{\Omega}$ & $\stackrel{m}{=}$ & $\approx$ & 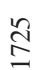 & $\stackrel{ \pm}{ \pm}$ & $\Phi$ & $\underset{\infty}{\infty}$ & $\stackrel{゚}{I}$ & $\stackrel{\infty}{\sim}$ & ळે & $\stackrel{\circ}{\infty}$ & $\stackrel{\infty}{\sim}$ & 守 & $\stackrel{\infty}{\infty}$ & $\stackrel{\infty}{\infty}$ & $\stackrel{\infty}{=}$ & $\stackrel{\Omega}{\beth}$ \\
\hline
\end{tabular}

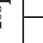

\begin{tabular}{|c|c|c|c|c|c|c|c|c|c|c|c|c|c|c|c|c|c|}
\hline$\stackrel{\cong}{=}$ & $\stackrel{n}{n}$ & తి & $\approx$ & $\tilde{\sigma}$ & 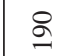 & $\stackrel{\Delta}{g}$ & $\underset{\infty}{\mathbb{J}}$ & $\cong$ & $\stackrel{\infty}{\Xi}$ & $\begin{array}{l}n \\
2 \\
\infty\end{array}$ & $\stackrel{\infty}{\infty}$ & $\stackrel{\infty}{\infty}$ & $\cong$ & $\stackrel{\infty}{\infty}$ & $\stackrel{\infty}{\infty}$ & $\stackrel{\infty}{\sim}$ & \\
\hline
\end{tabular}

䐱

$2+\infty \operatorname{mos} \pi$

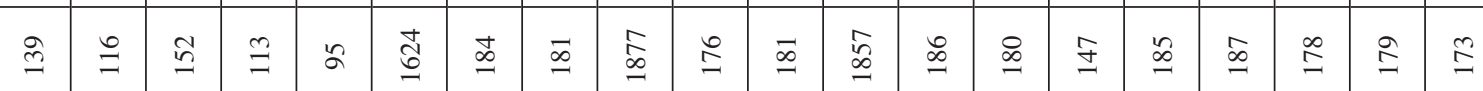

总

$\approx$

$=$

文

m 0

-

ก $=n$

$\infty \quad+\quad+\infty$

离

\begin{tabular}{|c|c|c|c|c|c|c|c|c|c|c|c|c|c|c|c|c|c|c|c|c|c|}
\hline : & 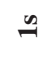 & $\infty$ & in & a & in & $n$ & $\stackrel{\circ}{\circ}$ & $\bar{\lambda}$ & in & $=$ & $\stackrel{\infty}{\sim}$ & $\stackrel{\infty}{\sim}$ & $=$ & t & $\hat{\imath}$ & ते & $n$ & $\stackrel{\infty}{\sim}$ & 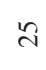 & $\stackrel{\infty}{\sim}$ & $\bar{\sigma}$ \\
\hline है। & & $\stackrel{\infty}{\stackrel{\sim}{~}}$ & $\stackrel{\text { I }}{\mathrm{q}}$ & $\Sigma$ & 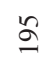 & స̃ & 官 & ్ㅠㅁ & 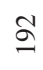 & $\underset{\infty}{\stackrel{n}{\infty}}$ & ठे & 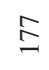 & $\begin{array}{l}\widetilde{\delta} \\
\infty \\
\sim\end{array}$ & $\tilde{ก}$ & $\overline{\mathrm{N}}$ & $\underset{\sim}{\stackrel{J}{~}}$ & $\vec{\sim}$ & ్ㅏ & $\stackrel{8}{\circ}$ & 过 & in \\
\hline
\end{tabular}

离

\begin{tabular}{|c|c|c|c|c|c|c|c|c|c|c|c|c|c|c|c|c|c|c|c|c|}
\hline$\simeq$ & $\begin{array}{l}\text { ô } \\
\delta \\
0\end{array}$ & $\begin{array}{l}\frac{m}{8} \\
8 \\
0\end{array}$ & 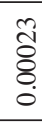 & $\begin{array}{l}\text { İ } \\
\text { ठे } \\
0 \\
\end{array}$ & $\begin{array}{l}\overline{8} \\
0 \\
0\end{array}$ & & 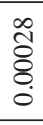 & & $\begin{array}{l}\text { oे } \\
\stackrel{\Xi}{0} \\
\text {. }\end{array}$ & $\begin{array}{l}\text { ¿े } \\
8 \\
0 \\
\end{array}$ & $\begin{array}{l}\text { ते } \\
\text { ठ } \\
0 \\
\end{array}$ & $\begin{array}{l}\text { ते } \\
\text { ठे. } \\
0 \\
0\end{array}$ & $\begin{array}{l}0 \\
\overline{8} \\
0 \\
\end{array}$ & $\begin{array}{l}\text { ते } \\
\text { ठे } \\
0 \\
0\end{array}$ & $\begin{array}{l}0 \\
8 \\
8 \\
\circ \\
\end{array}$ & 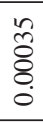 & $\begin{array}{l}0 \\
\delta \\
0\end{array}$ & $\begin{array}{l}\overline{0} \\
\stackrel{8}{0} \\
\stackrel{0}{0}\end{array}$ & 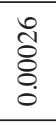 & 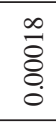 \\
\hline & $\begin{array}{l}\hat{\delta} \\
\delta \\
\delta \\
0\end{array}$ & $\begin{array}{l}\text { } \\
\tilde{\delta} \\
\delta \\
0\end{array}$ & $\begin{array}{l}\stackrel{8}{n} \\
\text { \&े } \\
0\end{array}$ & 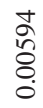 & 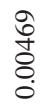 & 0 & 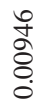 & & $\begin{array}{l}\tilde{2} \\
\stackrel{0}{\delta} \\
\end{array}$ & $\begin{array}{l}\approx \\
\approx \\
\stackrel{8}{0} \\
0\end{array}$ & $\begin{array}{l}\mathscr{0} \\
\infty \\
\& \\
0 \\
0\end{array}$ & $\begin{array}{l}\bar{\varpi} \\
\stackrel{0}{0} \\
\stackrel{0}{0}\end{array}$ & 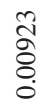 & क्षे & $\begin{array}{l}n \\
\tilde{n} \\
\delta \\
\delta \\
0\end{array}$ & ठ̊. & $\begin{array}{l}\text { t } \\
\stackrel{8}{0} \\
\stackrel{0}{0}\end{array}$ & $\begin{array}{l}\text { ôे } \\
\text { ठे } \\
\text { ᄋ. }\end{array}$ & $\begin{array}{l}+ \\
\infty \\
\infty \\
\& \\
0 \\
0\end{array}$ & $\begin{array}{l}\tilde{D} \\
8 \\
8 \\
0\end{array}$ \\
\hline
\end{tabular}

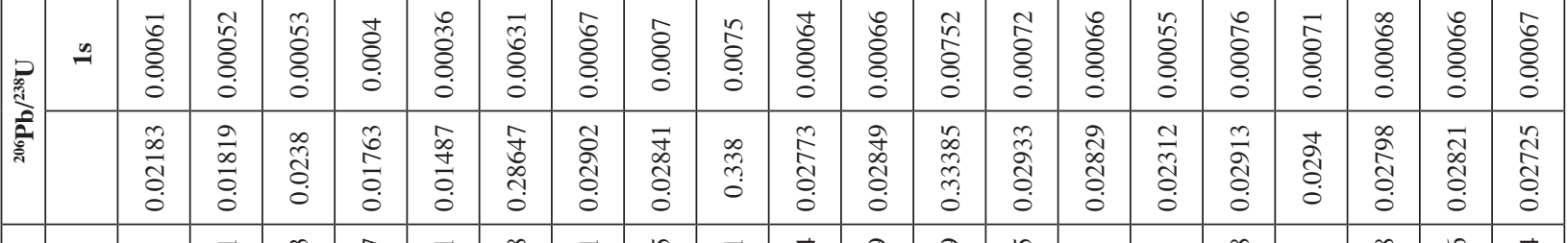

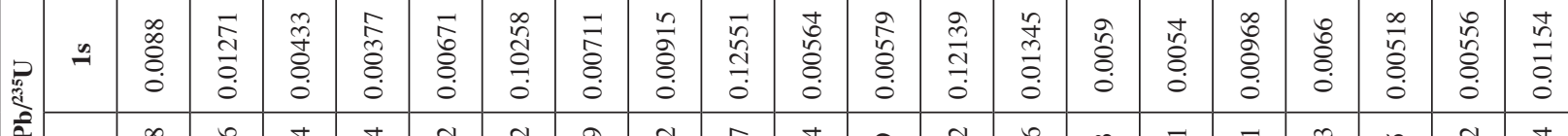

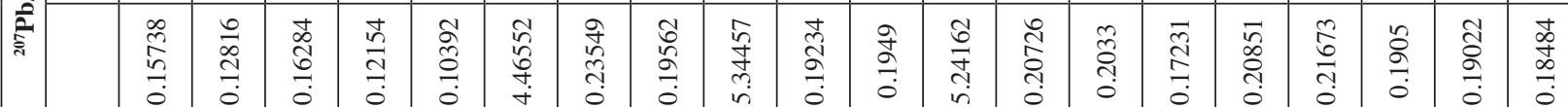

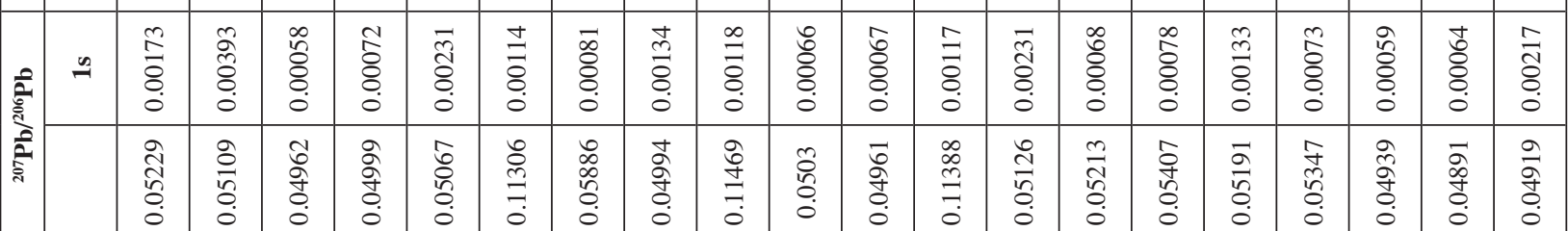

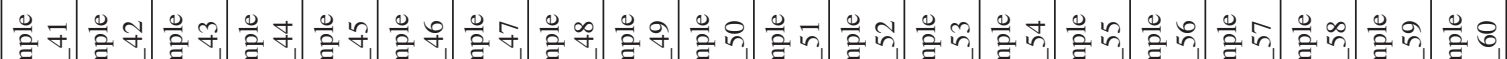

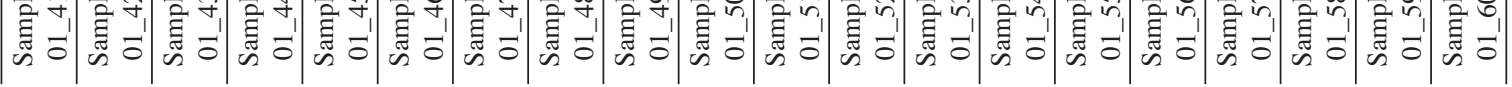




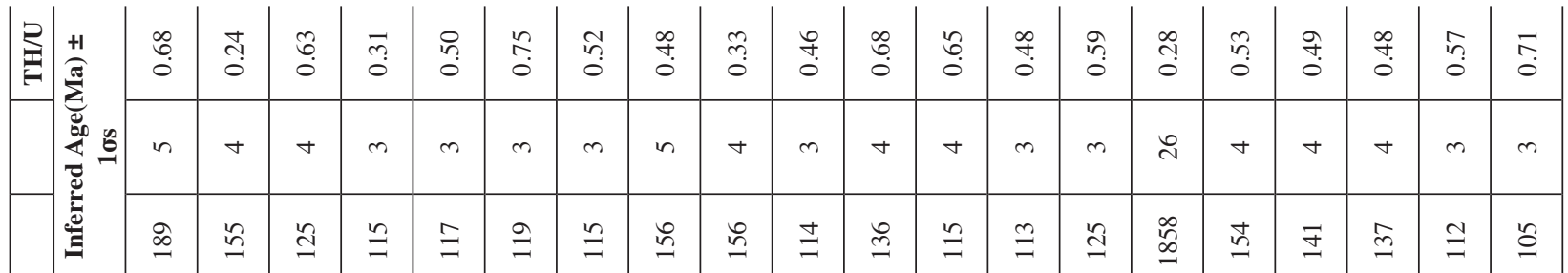

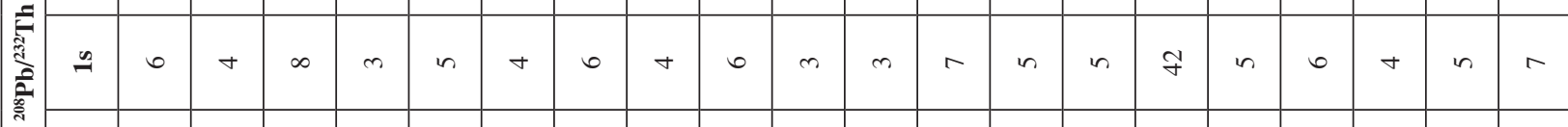

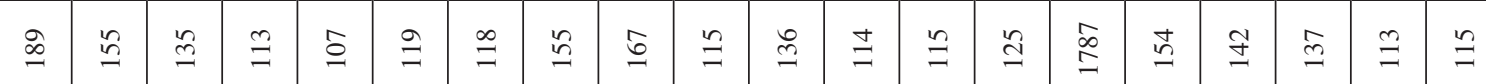
蛋

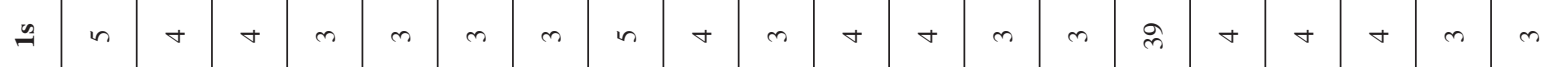

\begin{tabular}{|c|c|c|c|c|c|c|c|c|c|c|c|c|c|c|c|c|c|c|c|c|c|c|c|c|c|}
\hline$\stackrel{n}{n}$ & $\stackrel{\beth}{\beth}$ & $\stackrel{n}{=}$ & $\Xi$ & $\stackrel{2}{=}$ & 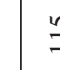 & & & & & & & & & & & & & & & & & & & & - \\
\hline
\end{tabular}

总 2 苞

\begin{tabular}{|c|c|c|c|c|c|c|c|c|c|c|c|c|c|c|c|c|c|c|c|}
\hline$\approx$ & पे & $\infty$ & $\stackrel{\infty}{\curvearrowright}$ & $\infty$ & $\widetilde{\sigma}$ & 寸 & $\vec{\sigma}$ & ले & $\vec{m}$ & 8 & gr & $\sqrt{n}$ & $\widehat{\infty}^{-}$ & $\stackrel{\circ}{ \pm}$ & $\underset{N}{ }$ & $\tilde{\Xi}$ & 壳 & 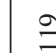 & $\stackrel{\infty}{ }$ \\
\hline
\end{tabular}
¿

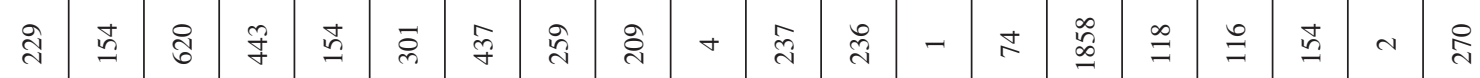
离

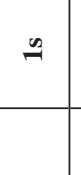

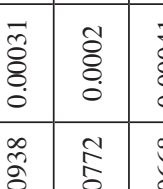

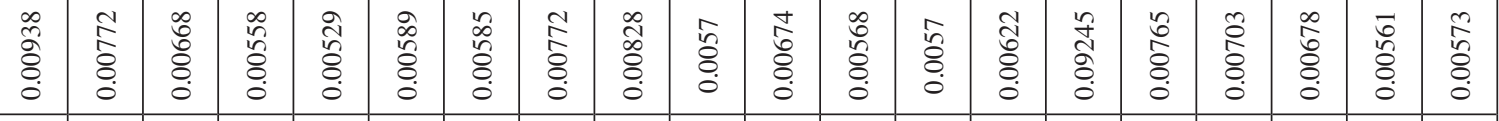

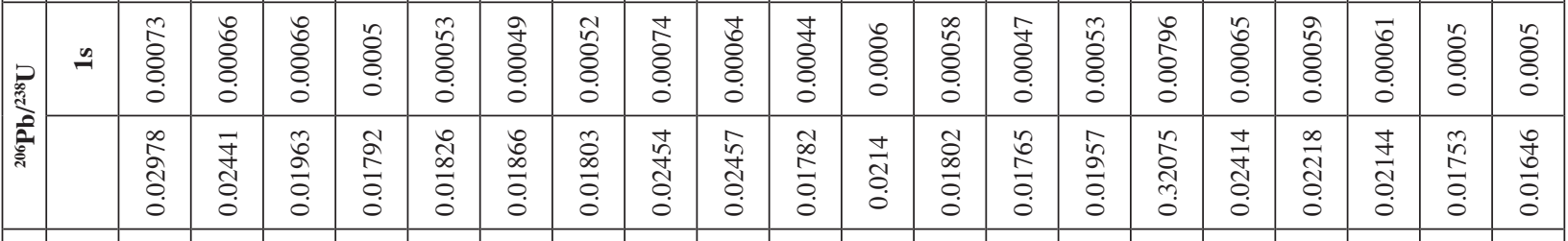

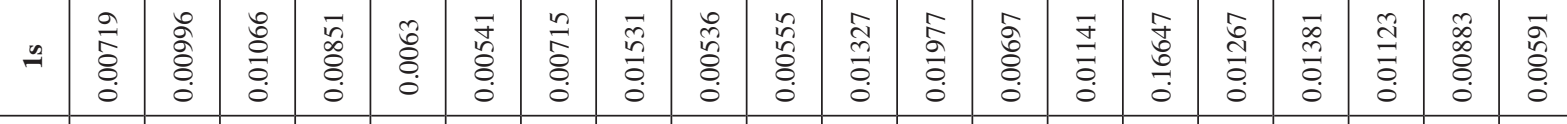

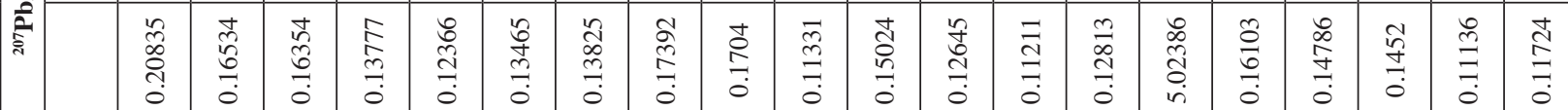

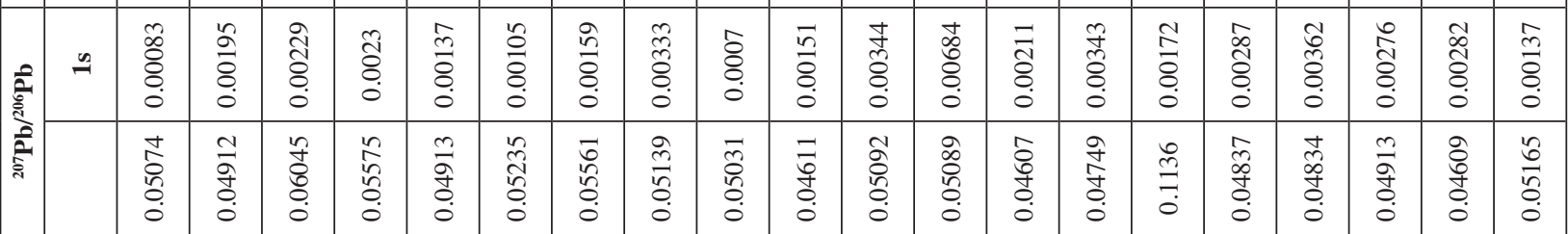

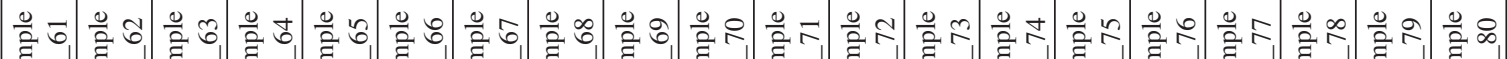

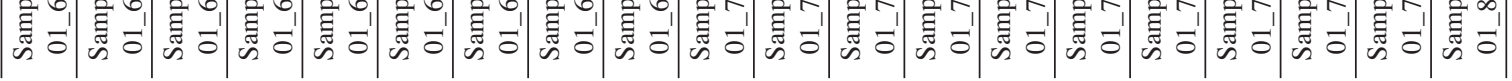




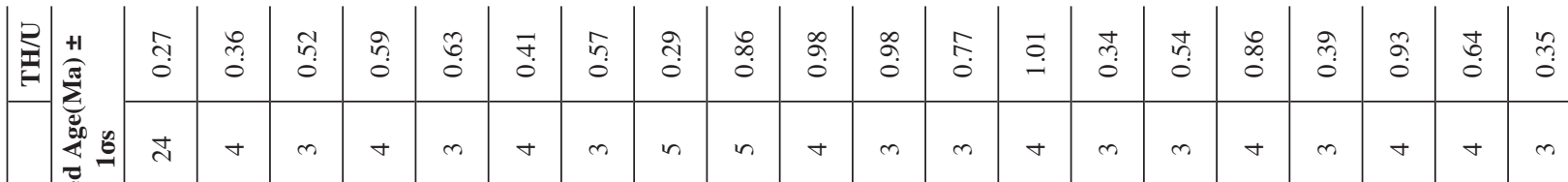

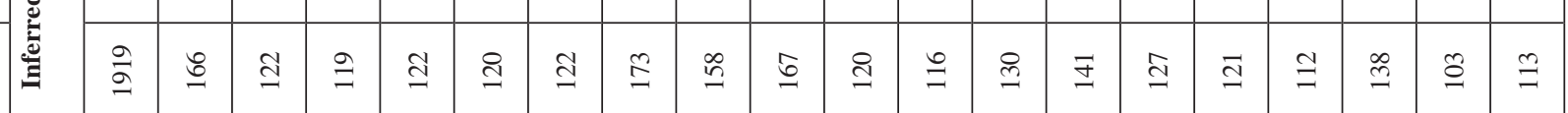

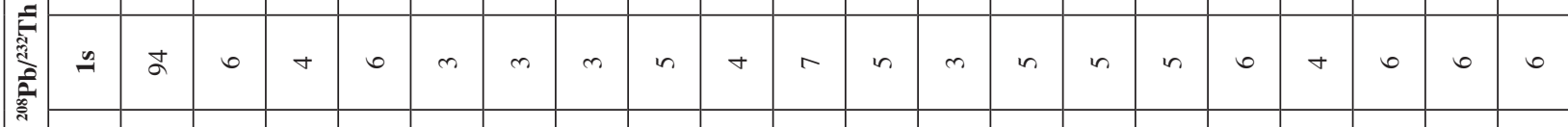

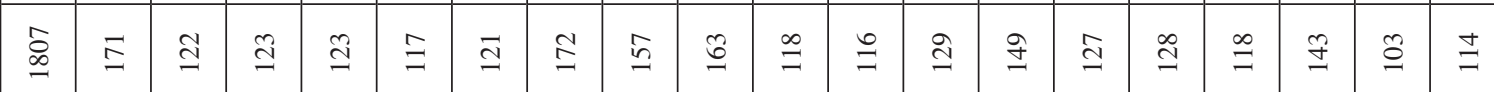

㠃

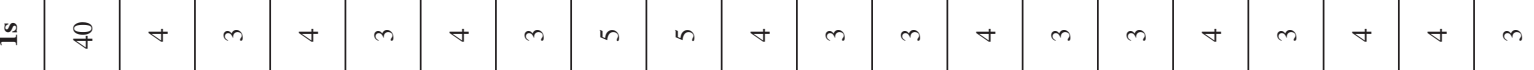

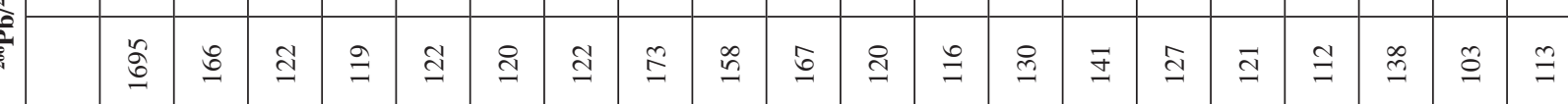
产

\begin{tabular}{|c|c|c|c|c|c|c|c|c|c|c|c|c|c|c|c|c|c|c|}
\hline$\hat{\imath}$ & in & $a$ & $r$ & $\infty$ & $\simeq$ & 으 & 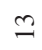 & $\simeq$ & in & + & $\simeq$ & $\infty$ & † & + & $\infty$ & + & $n$ & 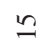 \\
\hline$\stackrel{\infty}{\stackrel{\infty}{I}}$ & $\vec{I}$ & త్తి & $\exists$ & తి & $\stackrel{f}{I}$ & $\cong$ & $\stackrel{\infty}{=}$ & $\underline{\sigma}$ & $\underset{\infty}{\stackrel{\infty}{0}}$ & $\Xi$ & తి & $\stackrel{\circ}{n}$ & $\stackrel{?}{q}$ & $\overrightarrow{\underline{m}}$ & $\stackrel{I}{\exists}$ & $\stackrel{\infty}{=}$ & $\stackrel{\infty}{=}$ & $\underset{\Xi}{\stackrel{t}{O}}$ \\
\hline
\end{tabular}

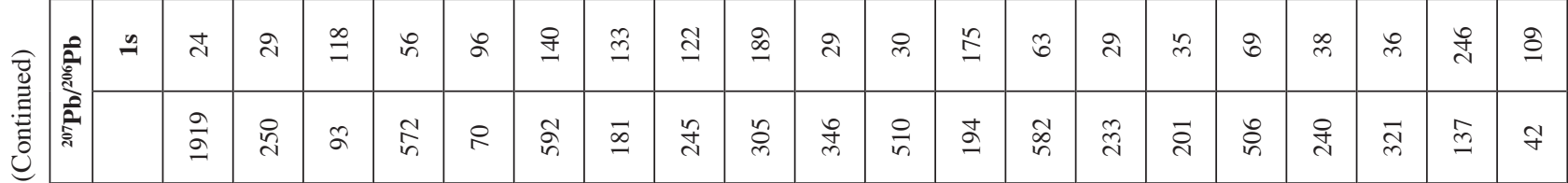

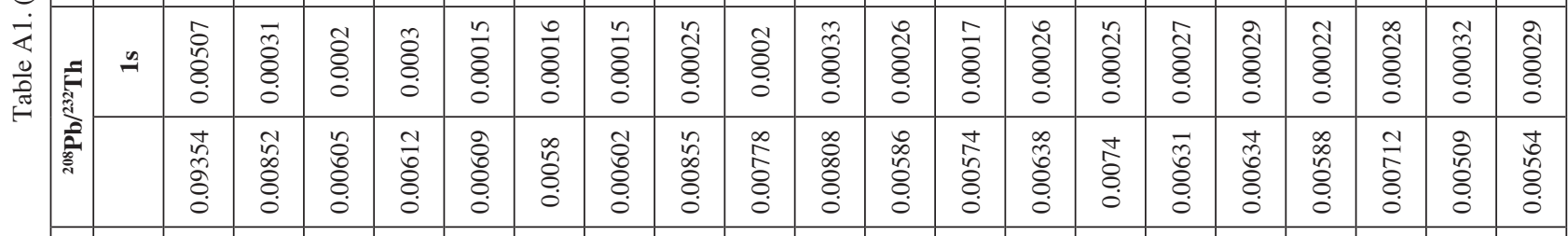

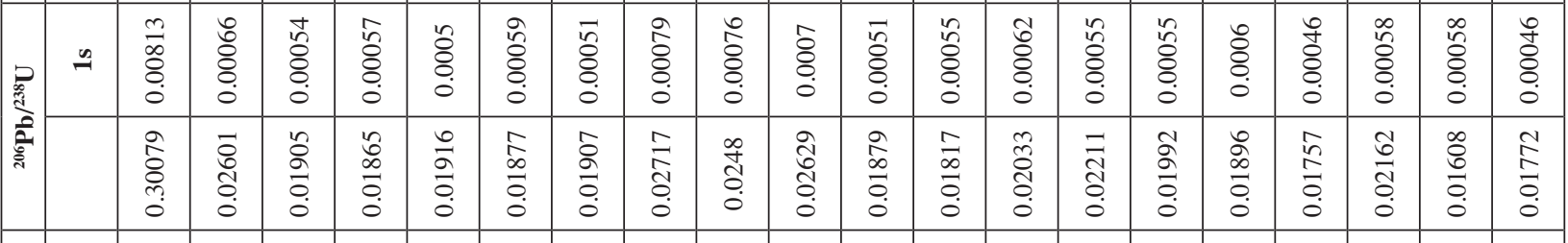

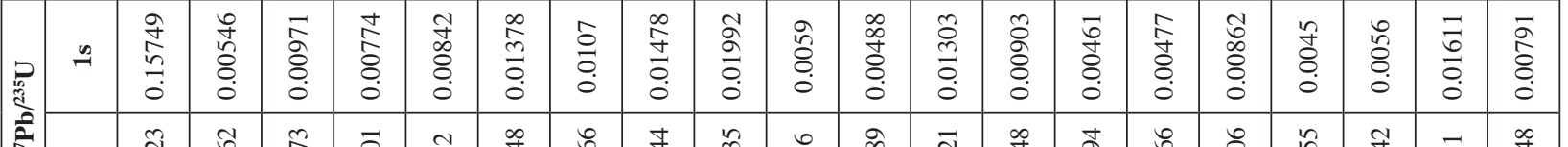

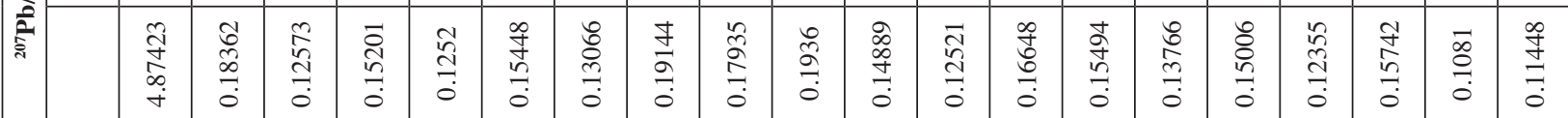

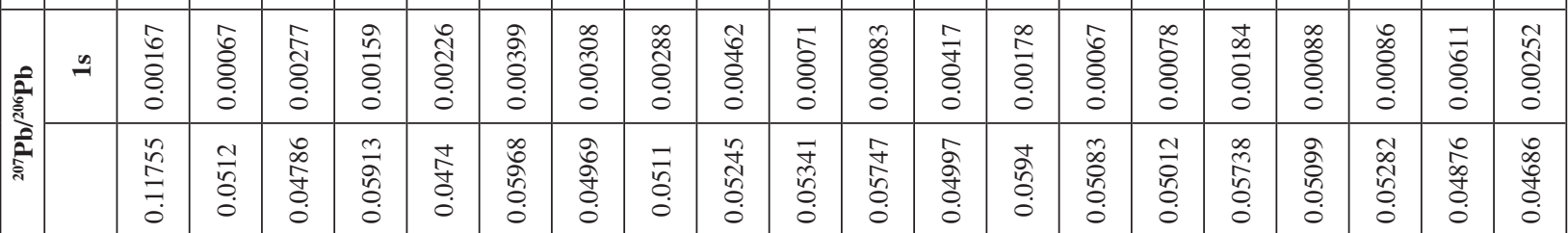

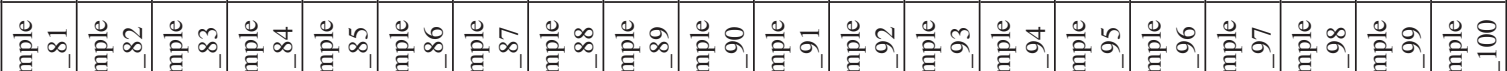

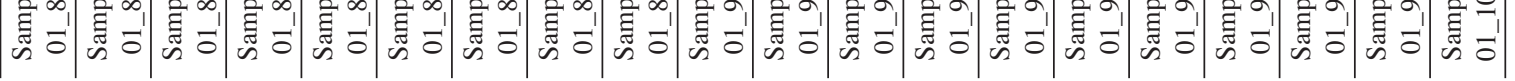




\begin{tabular}{|c|c|c|c|c|c|c|c|c|}
\hline \multirow{2}{*}{2} & \multirow{2}{*}{ 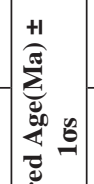 } & $\stackrel{?}{+}$ & $\stackrel{\infty}{\infty}$ & 吕 & in & $\underset{0}{0}$ & సิ & 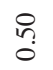 \\
\hline & & $r$ & 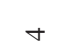 & 0 & 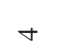 & + & in & $n$ \\
\hline \multirow{3}{*}{ 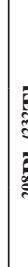 } & 节 & $\stackrel{n}{n}$ & $\stackrel{\infty}{\stackrel{\leftrightarrow}{\circ}}$ & $\Xi$ & $\stackrel{8}{ }$ & $\Xi$ & $\infty$ & సิ \\
\hline & $\simeq$ & $r$ & $ナ$ & 0 & ナ & $\nabla$ & in & $n$ \\
\hline & & $\stackrel{n}{n}$ & $\stackrel{\infty}{0}$ & $\exists$ & $\stackrel{\circ}{\circ}$ & $\Xi$ & $\infty$ & సิ \\
\hline \multirow[t]{2}{*}{2} & 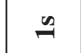 & in & m & 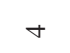 & n & $m$ & $m$ & $m$ \\
\hline & & $\overrightarrow{\underline{\sigma}}$ & $\Xi$ & $\sqrt{n}$ & $\stackrel{\infty}{=}$ & $\Xi$ & $\cong$ & $\stackrel{n}{\varrho}$ \\
\hline \multirow{2}{*}{ 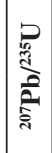 } & $\leadsto$ & 6 & $\nabla$ & in & 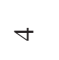 & 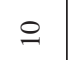 & in & 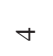 \\
\hline & & $\Xi$ & $\stackrel{\infty}{=}$ & $\stackrel{\leftrightarrow}{2}$ & $\stackrel{\infty}{\exists}$ & $\exists$ & $\cong$ & ले \\
\hline \multirow{2}{*}{ 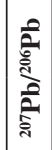 } & 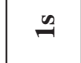 & $\mathscr{f}$ & ले & $\stackrel{i}{i}$ & $\stackrel{i}{i}$ & 으 & $\hat{n}$ & $\tilde{ల}$ \\
\hline & & స్ల & 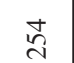 & $\ddot{n}$ & $\cong$ & $\stackrel{\infty}{=}$ & ले & $\stackrel{\vec{N}}{ }$ \\
\hline \multirow{2}{*}{ 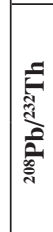 } & $\simeq$ & $\begin{array}{l}\tilde{\sigma} \\
\delta \\
\delta \\
0\end{array}$ & $\begin{array}{l}\grave{\bar{\delta}} \\
\dot{\Xi} \\
\dot{0}\end{array}$ & $\begin{array}{l}\infty \\
\tilde{\Xi} \\
\delta \\
0\end{array}$ & $\begin{array}{l}\infty \\
\stackrel{\infty}{0} \\
\stackrel{0}{0}\end{array}$ & $\begin{array}{l}\tilde{\delta} \\
\delta \\
0 \\
0\end{array}$ & $\begin{array}{l}\text { ते } \\
\delta \\
\delta \\
0 \\
0\end{array}$ & 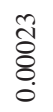 \\
\hline & & $\begin{array}{l}\overrightarrow{0} \\
\tilde{8} \\
0 \\
0\end{array}$ & $\begin{array}{l}\infty \\
\tilde{n} \\
\delta \\
\delta \\
0\end{array}$ & $\tilde{8}$ & $\begin{array}{l}\text { I } \\
\text { Hิ } \\
8 \\
0 \\
0\end{array}$ & \begin{tabular}{l}
0 \\
\multirow{2}{0}{} \\
8 \\
0 \\
0
\end{tabular} & \begin{tabular}{l}
$\hat{m}$ \\
\multirow{8}{8}{} \\
0 \\
0
\end{tabular} & \begin{tabular}{l} 
ते \\
\multirow{0}{0}{} \\
0
\end{tabular} \\
\hline \multirow{2}{*}{ 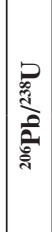 } & $\simeq$ & $\begin{array}{l}\tilde{N} \\
\tilde{\delta} \\
8 \\
0\end{array}$ & $\begin{array}{l}0 \\
0 \\
8 \\
8 \\
0 \\
0\end{array}$ & $\begin{array}{l}\mathscr{0} \\
8 \\
8 \\
0\end{array}$ & $\begin{array}{l}\text { fे } \\
\text { o } \\
0 \\
0\end{array}$ & $\begin{array}{l}n \\
\tilde{\delta} \\
0 \\
0\end{array}$ & 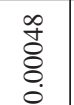 & $\begin{array}{l}\tilde{2} \\
\tilde{\delta} \\
0 \\
0\end{array}$ \\
\hline & & $\begin{array}{l}\text { U. } \\
\text { ปे } \\
0 \\
0\end{array}$ & 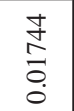 & $\begin{array}{l}\text { ôd } \\
\text { त̂. } \\
0 \\
0\end{array}$ & $\begin{array}{l}\frac{1}{1} \\
\stackrel{0}{0} \\
\stackrel{0}{0} \\
0\end{array}$ & $\begin{array}{l}\tilde{N} \\
\tilde{\Sigma} \\
0 \\
0 \\
0\end{array}$ & $\begin{array}{l} \\
\text { +1 } \\
0 \\
0 \\
0\end{array}$ & $\begin{array}{l}\stackrel{J}{\Xi} \\
\stackrel{\widetilde{\sigma}}{O} \\
\stackrel{0}{0}\end{array}$ \\
\hline \multirow{2}{*}{ 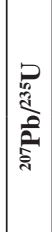 } & $\simeq$ & \begin{tabular}{l}
$n$ \\
\multirow{8}{8}{} \\
0
\end{tabular} & 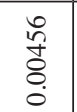 & $\begin{array}{l}8 \\
\infty \\
o \\
0 \\
0 \\
0\end{array}$ & $\begin{array}{l}\frac{9}{\sigma} \\
\stackrel{\sigma}{0} \\
\dot{0}\end{array}$ & 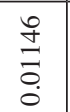 & $\begin{array}{l}\circ \\
\stackrel{\circ}{8} \\
8 \\
0\end{array}$ & $\begin{array}{l}\vec{T} \\
\stackrel{+}{8} \\
8 \\
0\end{array}$ \\
\hline & & $\begin{array}{l}\frac{f}{f} \\
0 \\
0 \\
0\end{array}$ & 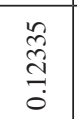 & $\begin{array}{l}\frac{n}{0} \\
0 \\
0 \\
0\end{array}$ & $\begin{array}{l}\stackrel{1}{\hat{~}} \\
\stackrel{3}{0}\end{array}$ & $\begin{array}{l}0 \\
n \\
\stackrel{n}{=} \\
0\end{array}$ & $\begin{array}{l}\text { 今े } \\
\text { ఫ. }\end{array}$ & $\begin{array}{l}\underset{\mathbb{N}}{\tilde{S}} \\
\stackrel{0}{0}\end{array}$ \\
\hline \multirow{2}{*}{ 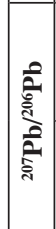 } & $\cong$ & $\begin{array}{l}\tilde{0} \\
\stackrel{0}{\sigma} \\
0 \\
0\end{array}$ & $\begin{array}{l}\text { oे } \\
\text { o. }\end{array}$ & $\begin{array}{l}\overrightarrow{0} \\
\dot{8} \\
\dot{0}\end{array}$ & 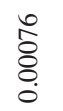 & $\begin{array}{l}\infty \\
\infty \\
\stackrel{\delta}{8} \\
0 \\
0\end{array}$ & $\begin{array}{l}\overline{\mathrm{a}} \\
\stackrel{8}{8}\end{array}$ & 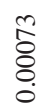 \\
\hline & & $\begin{array}{l}\text { ¿ } \\
\text { ते } \\
\text { o. } \\
0\end{array}$ & 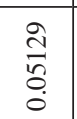 & $\begin{array}{l}\hat{\infty} \\
\hat{O} \\
o \\
0 \\
0\end{array}$ & 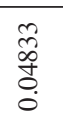 & 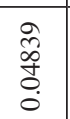 & $\begin{array}{l}\overrightarrow{0} \\
\text { ह̂. } \\
0 \\
0\end{array}$ & 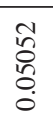 \\
\hline & & 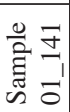 & $n 0$ & & as & & & \\
\hline
\end{tabular}

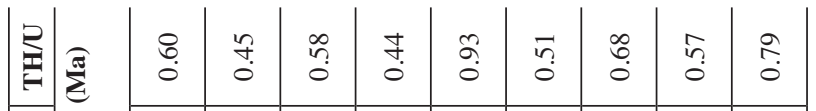

\begin{tabular}{|c|c|c|c|c|c|c|c|c|c|}
\hline 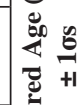 & in & in & तิ & $n$ & 0 & $a$ & $\nabla$ & in & $n$ \\
\hline$\stackrel{\bar{\Xi}}{\Xi}$ & 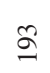 & $\stackrel{\infty}{\sim}$ & $\stackrel{\sim}{\infty}$ & $\stackrel{ \pm}{\sigma}$ & $\stackrel{\infty}{\sim}$ & $\stackrel{\infty}{\infty}$ & in & $\underset{\infty}{ \pm}$ & $\hat{\sigma}$ \\
\hline
\end{tabular}

粦

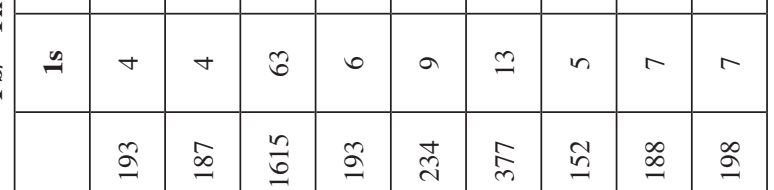

\begin{tabular}{|c|c|c|c|c|c|c|c|c|}
\hline$\simeq$ & in & $n$ & m & $n$ & 0 & $a$ & $\nabla$ & in \\
\hline & 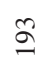 & $\stackrel{\infty}{\infty}$ & こิ & $\Xi$ & $\stackrel{\infty}{\sim}$ & $\begin{array}{l}\mathscr{\infty} \\
\infty \\
\infty\end{array}$ & in & $\stackrel{ \pm}{\square}$ \\
\hline
\end{tabular}

\begin{tabular}{|c|c|c|c|c|c|c|c|c|c|}
\hline 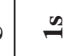 & \pm & $\Xi$ & $\tilde{N}$ & in & 0 & $a$ & in & 0 & 6 \\
\hline & $\Omega$ & $\stackrel{\infty}{\varrho}$ & $\stackrel{\sim}{\infty}$ & "ి & 突 & $\stackrel{\infty}{\infty}$ & 8 & 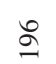 & $\bar{c}$ \\
\hline
\end{tabular}

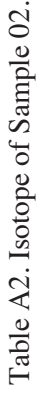

\begin{tabular}{|c|c|c|c|c|c|c|c|c|c|}
\hline 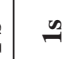 & $\Xi$ & $\Xi$ & ন & $\bar{\lambda}$ & ते & $\bar{\lambda}$ & ৪ & $\vec{m}$ & ల \\
\hline & $\bar{\Omega}$ & $\stackrel{n}{\text { n్ }}$ & $\underset{\infty}{\infty}$ & $\vec{m}$ & ते & 요 & ठิ & $\stackrel{\infty}{m}$ & $\overrightarrow{\tilde{U}}$ \\
\hline
\end{tabular}

要

\begin{tabular}{|c|c|c|c|c|c|c|c|c|c|}
\hline$\cong$ & $\begin{array}{l}\text { ô } \\
\text { o. }\end{array}$ & 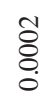 & $\begin{array}{l}\text { ले } \\
\text { } \\
\text { }\end{array}$ & $\begin{array}{l}\bar{\delta} \\
\dot{\delta} \\
\delta\end{array}$ & $\begin{array}{l}\text { 寺 } \\
8 \\
0 \\
0\end{array}$ & 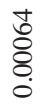 & 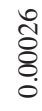 & 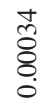 & 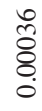 \\
\hline & $\begin{array}{l}\text { ồ } \\
\hat{o} \\
\text { o. }\end{array}$ & $\begin{array}{l}\text { న̂ } \\
\hat{\delta} \\
0\end{array}$ & $\begin{array}{l}\widetilde{N} \\
\infty \\
0 \\
0\end{array}$ & $\begin{array}{l}\hat{\alpha} \\
\hat{o} \\
\text { o. }\end{array}$ & $\begin{array}{l}n \\
0 \\
0 \\
0 \\
0\end{array}$ & $\begin{array}{l}\tilde{O} \\
\infty \\
\infty \\
\stackrel{0}{0} \\
0\end{array}$ & $\begin{array}{l}\hat{\kappa} \\
\tilde{8} \\
0\end{array}$ & 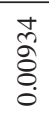 & $\begin{array}{l}\mathscr{2} \\
0 \\
0 \\
0 \\
0\end{array}$ \\
\hline & $\underset{\infty}{ \pm}$ & 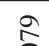 & $i$ & $\stackrel{n}{5}$ & $\bar{a}$ & $\approx$ & $\delta$ & $n$ & \\
\hline
\end{tabular}

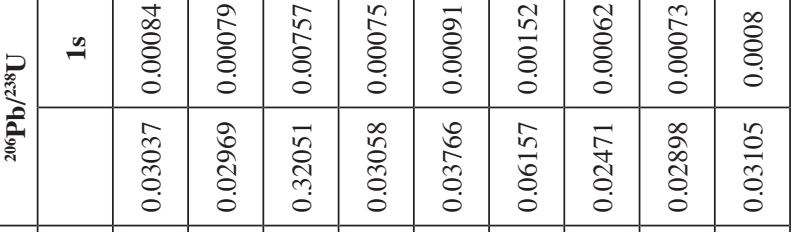

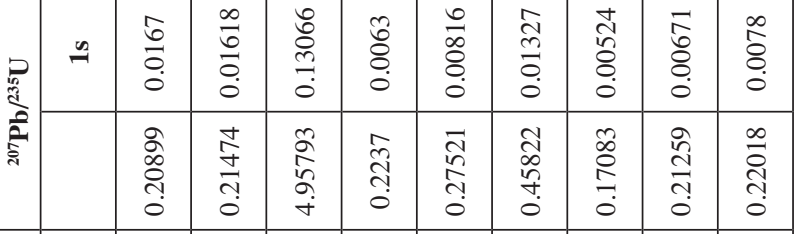

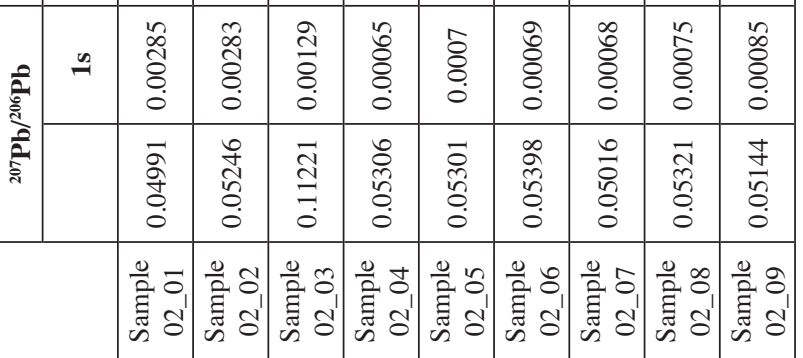




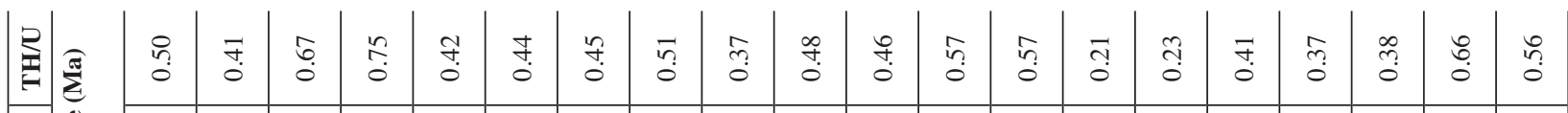
\begin{tabular}{|l|l|l|l|l|l|l|l|l|l|l|l|l|l|l|l|l|l|l|l|}
\hline \\
\hline
\end{tabular}

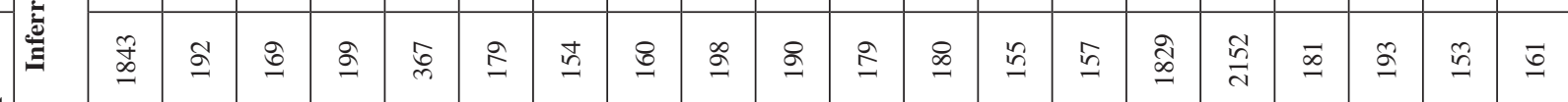

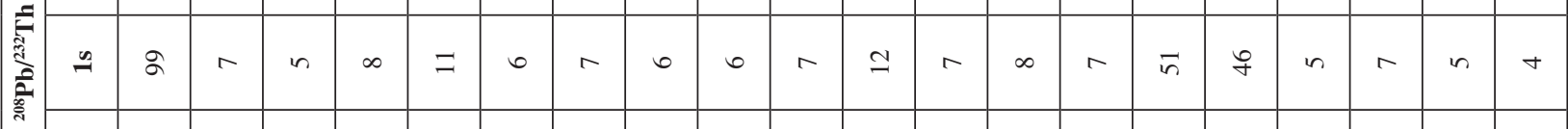

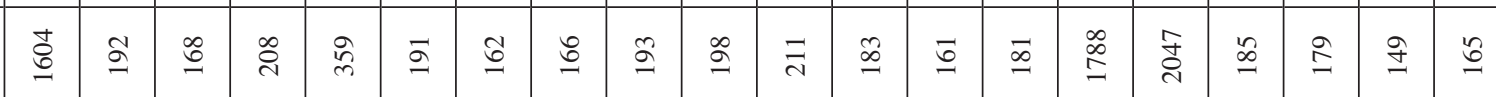

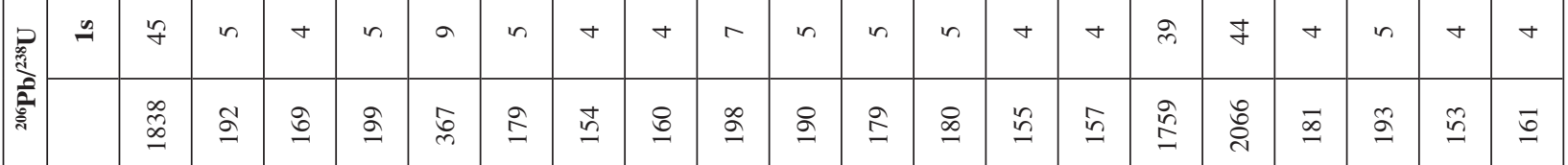

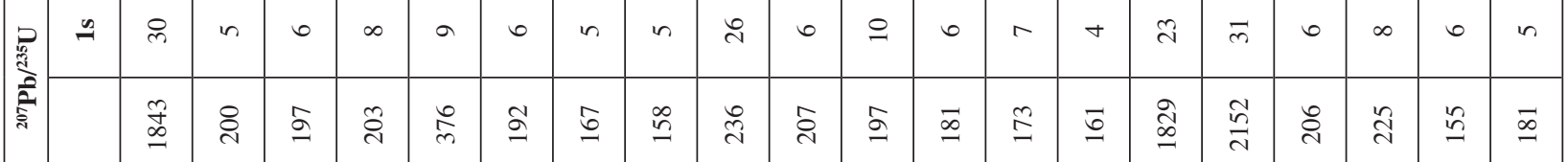

\begin{tabular}{|c|c|c|c|c|c|c|c|c|c|c|c|c|c|c|c|c|c|c|c|c|c|}
\hline \multirow{2}{*}{ 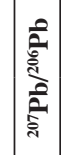 } & & & & ते & g & & ల & 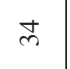 & $\tilde{m}$ & $\stackrel{\infty}{=}$ & $\approx$ & $\tau$ & of & $\stackrel{\infty}{+}$ & ते & $\stackrel{\sim}{.}$ & d & ते & f & $F$ & ते \\
\hline & & 季 & $\stackrel{\vec{\sim}}{\vec{c}}$ & go & $\vec{d}$ & $\vec{q}$ & బర & fै & $\vec{m}$ & ठે & $\stackrel{\infty}{\infty}$ & $\stackrel{n}{\exists}$ & $\stackrel{g}{g}$ & $\bar{q}$ & $\stackrel{\circ}{N}$ & 9 & तु & m & : & $\stackrel{ \pm}{\sim}$ & 亲 \\
\hline
\end{tabular}

군 离

\begin{tabular}{|c|c|c|c|c|c|c|c|c|c|c|c|c|c|c|c|c|c|c|c|c|c|}
\hline \multirow{2}{*}{ 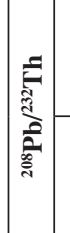 } & $\simeq$ & $\begin{array}{l}\tilde{0} \\
\stackrel{0}{0} \\
0\end{array}$ & & $\begin{array}{l}0 \\
\text { षे } \\
0\end{array}$ & 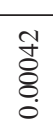 & $\begin{array}{l}0 \\
0 \\
0 \\
0 \\
0\end{array}$ & ठ̊. & $\begin{array}{l}\text { 䓌 } \\
\stackrel{0}{0}\end{array}$ & $\begin{array}{l}\text { के } \\
\stackrel{0}{0}\end{array}$ & 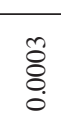 & $\begin{array}{l}\text { o. } \\
\stackrel{0}{0} \\
0 \\
0\end{array}$ & $\begin{array}{l}\infty \\
0 \\
0 \\
0 \\
0\end{array}$ & 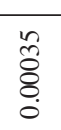 & 䒱 & $\begin{array}{l}n \\
0 \\
0 \\
0 \\
0\end{array}$ & $\begin{array}{l}\text { 志 } \\
\text { Oे }\end{array}$ & $\begin{array}{l}\text { वें } \\
\stackrel{0}{0}\end{array}$ & $\begin{array}{l} \\
\text { ठ̊̆ } \\
0 \\
0\end{array}$ & 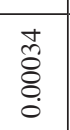 & $\begin{array}{l}\text { ț } \\
\text { ठ̊ } \\
0 \\
0\end{array}$ & $\begin{array}{l}\text { ते } \\
\text { ठे. } \\
0\end{array}$ \\
\hline & & $\begin{array}{l}\text {. } \\
\stackrel{0}{0} \\
0\end{array}$ & 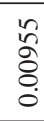 & $\begin{array}{l}0 \\
0 \\
0 \\
0 \\
0 \\
0\end{array}$ & $\begin{array}{l}\text { mo } \\
\frac{\hat{o}}{0} \\
0\end{array}$ & 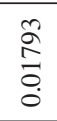 & $\begin{array}{l}\text { 守 } \\
\text { के } \\
0\end{array}$ & $\begin{array}{l}\text { 品 } \\
0 \\
0 \\
0\end{array}$ & 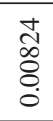 & 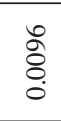 & $\begin{array}{l}0 \\
0 \\
0 \\
0 \\
0\end{array}$ & $\begin{array}{l}\overrightarrow{\overrightarrow{0}} \\
0 \\
0 \\
0\end{array}$ & $\begin{array}{l}\overline{\text { I }} \\
\dot{0} \\
\end{array}$ & 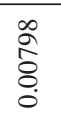 & $\begin{array}{l}\infty \\
0 \\
0 \\
0 \\
0\end{array}$ & 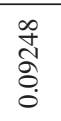 & $\begin{array}{l}0 \\
0 \\
0 \\
0 \\
0 \\
0\end{array}$ & $\begin{array}{l}\overrightarrow{1} \\
\bar{\delta} \\
0 \\
0\end{array}$ & $\begin{array}{l} \\
\stackrel{0}{o} \\
\stackrel{0}{0}\end{array}$ & $\begin{array}{l}\infty \\
0 \\
0 \\
0 \\
0\end{array}$ & $\begin{array}{l}\frac{\infty}{0} \\
0 \\
0 \\
0 \\
0\end{array}$ \\
\hline \multirow{2}{*}{ 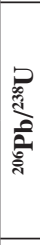 } & 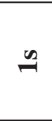 & $\begin{array}{l}\text { "ू } \\
8 \\
8 \\
0\end{array}$ & 客 & $\begin{array}{l} \\
\vdots \\
0 \\
0\end{array}$ & $\begin{array}{l}\bar{\alpha} \\
\stackrel{0}{0} \\
0\end{array}$ & $\begin{array}{l}\frac{18}{8} \\
\frac{9}{8} \\
0\end{array}$ & 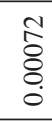 & 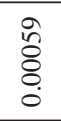 & $\begin{array}{l}0 \\
0 \\
0 \\
0\end{array}$ & 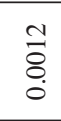 & $\begin{array}{l} \\
\\
\vdots \\
0 \\
0\end{array}$ & $\begin{array}{l} \\
0 \\
0 \\
0 \\
0\end{array}$ & 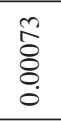 & $\begin{array}{l} \\
\\
\vdots \\
0 \\
0\end{array}$ & $\begin{array}{l}\overrightarrow{0} \\
\\
\end{array}$ & $\begin{array}{l}\infty \\
0 \\
0 \\
0 \\
0\end{array}$ & $\begin{array}{l}0 \\
\tilde{0} \\
0 \\
0 \\
0\end{array}$ & $\begin{array}{l}0 \\
0 \\
0 \\
0\end{array}$ & $\begin{array}{l}1 \\
0 \\
0 \\
0\end{array}$ & $\begin{array}{l}0 \\
0 \\
0 \\
0\end{array}$ & 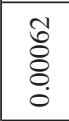 \\
\hline & & $\begin{array}{l}\text { बे } \\
\text { है }\end{array}$ & 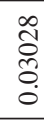 & 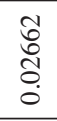 & 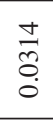 & $\begin{array}{l}\infty \\
0 \\
0 \\
0 \\
0 \\
0\end{array}$ & $\begin{array}{l}\mathbb{0} \\
\stackrel{0}{0}\end{array}$ & 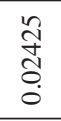 & $\begin{array}{l}\text { nn } \\
\text { ñ. } \\
0 \\
0\end{array}$ & $\begin{array}{l}\stackrel{3}{7} \\
\stackrel{0}{0}\end{array}$ & 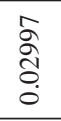 & $\begin{array}{l}\overparen{D} \\
\widetilde{d} \\
\stackrel{0}{0}\end{array}$ & 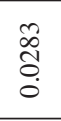 & 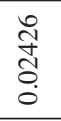 & $\begin{array}{l}\text { 等 } \\
\text { d. } \\
\end{array}$ & 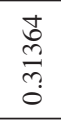 & $\begin{array}{l}m \\
\hat{E} \\
0 \\
0\end{array}$ & 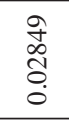 & \begin{tabular}{l}
0 \\
\multirow{0}{0}{} \\
0 \\
0 \\
0
\end{tabular} & $\begin{array}{l}\overrightarrow{0} \\
\text { d̦ } \\
\text { d. }\end{array}$ & 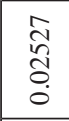 \\
\hline \multirow[t]{2}{*}{ 巢 } & $\underline{\sim}$ & $\begin{array}{l}\infty \\
0 \\
\infty \\
0 \\
0\end{array}$ & हू. & 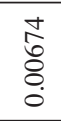 & $\begin{array}{l}\text { Õ } \\
\bar{o} \\
0 \\
0\end{array}$ & 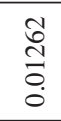 & 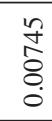 & $\begin{array}{l}\text { 总 } \\
\text { o. }\end{array}$ & $\begin{array}{l}\text { 市 } \\
0 \\
0 \\
0 \\
0\end{array}$ & $\begin{array}{l}\frac{\infty}{0} \\
\stackrel{0}{0} \\
\stackrel{0}{0}\end{array}$ & 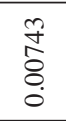 & $\stackrel{a}{0}$ & $\begin{array}{l}\text { ते } \\
\hat{\tilde{\Delta}} \\
\text {. }\end{array}$ & $\begin{array}{l}\tilde{a} \\
\stackrel{0}{0} \\
0\end{array}$ & $\begin{array}{l}0 \\
\text { : } \\
0 \\
0 \\
0\end{array}$ & $\begin{array}{l}\text { 总 } \\
\stackrel{8}{0}\end{array}$ & 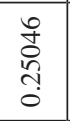 & $\begin{array}{l}\text { o } \\
0 \\
0 \\
0\end{array}$ & $\begin{array}{l}\hat{\tilde{0}} \\
\hat{0} \\
0\end{array}$ & 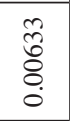 & 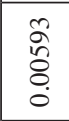 \\
\hline & & $\frac{\vec{T}}{\vec{i}}$ & $\stackrel{9}{I}$ & 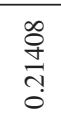 & 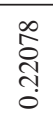 & 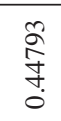 & 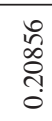 & 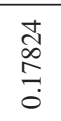 & $\begin{array}{l}\text { 总 } \\
\stackrel{0}{0} \\
\end{array}$ & 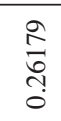 & $\begin{array}{l}\text { o } \\
\text { ते } \\
\text { d. }\end{array}$ & $\begin{array}{l}\frac{\tilde{y}}{\tilde{y}} \\
\frac{\tilde{y}}{\mathrm{O}}\end{array}$ & $\begin{array}{l}\frac{m}{0} \\
\frac{m}{0} \\
\frac{0}{0}\end{array}$ & 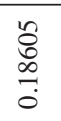 & 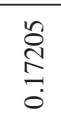 & 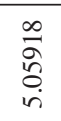 & 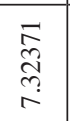 & $\begin{array}{l}\text { mo } \\
\text { त्र } \\
\text { d. }\end{array}$ & 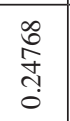 & $\begin{array}{l}\text { ro } \\
\text { 血 } \\
0\end{array}$ & $\begin{array}{l}\text { 蒿 } \\
\text { Oे }\end{array}$ \\
\hline \multirow[t]{2}{*}{ 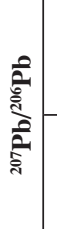 } & 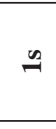 & $\begin{array}{l}\infty \\
\stackrel{0}{8} \\
0\end{array}$ & $\begin{array}{l}8 \\
\stackrel{8}{\circ} \\
\vdots\end{array}$ & $\begin{array}{l}0 \\
0 \\
0 \\
0 \\
\end{array}$ & $\begin{array}{l}m \\
\stackrel{m}{3} \\
0\end{array}$ & $\begin{array}{l} \\
\vdots \\
0 \\
0\end{array}$ & $\begin{array}{l}\bar{\sigma} \\
\overline{8} \\
0 \\
\end{array}$ & $\begin{array}{l}+5 \\
\text { o. } \\
0 \\
\end{array}$ & $\begin{array}{l} \\
\overline{8} \\
0 \\
0\end{array}$ & $\begin{array}{l}0 \\
0 \\
0 \\
0 \\
0\end{array}$ & $\begin{array}{l}\text { ô } \\
\stackrel{0}{0} \\
0 \\
0\end{array}$ & $\begin{array}{l}\Omega \\
\hat{\sigma} \\
0 \\
0\end{array}$ & $\begin{array}{l} \\
\text { oे } \\
\end{array}$ & 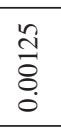 & $\begin{array}{l}0 \\
\\
0 \\
\end{array}$ & $\begin{array}{l}\infty \\
0 \\
0 \\
0 \\
0 \\
\end{array}$ & $\begin{array}{l} \\
\stackrel{0}{1} \\
\delta \\
0\end{array}$ & \begin{tabular}{|l|}
$\infty$ \\
0 \\
0 \\
0 \\
\end{tabular} & $\begin{array}{l}m \\
\overrightarrow{0} \\
0\end{array}$ & $\begin{array}{l}\overline{\hat{\sigma}} \\
\text { } \\
0\end{array}$ & 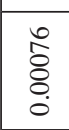 \\
\hline & & $\begin{array}{l}\text { ôे } \\
\stackrel{0}{0} \\
0\end{array}$ & : & $\begin{array}{l}+0 \\
0 \\
0 \\
0 \\
0 \\
0\end{array}$ & $\begin{array}{l}\bar{a} \\
\overrightarrow{0} \\
0 \\
0\end{array}$ & $\begin{array}{l} \\
f \\
0 \\
0 \\
0 \\
0 \\
0\end{array}$ & $\begin{array}{l}\text { to } \\
\tilde{\delta} \\
0 \\
0\end{array}$ & 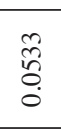 & 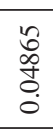 & 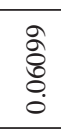 & $\begin{array}{l} \\
\text { ơ } \\
0 \\
0 \\
0 \\
0\end{array}$ & $\begin{array}{l}0 \\
\stackrel{0}{h} \\
0 \\
0 \\
0\end{array}$ & $\begin{array}{l}\text { 容 } \\
\text { o. }\end{array}$ & $\begin{array}{l}\text { 总 } \\
\text { o. } \\
0 \\
0\end{array}$ & 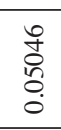 & $\begin{array}{l}\Xi \\
0\end{array}$ & 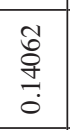 & $\begin{array}{l} \\
\tilde{\delta} \\
\delta \\
0 \\
0\end{array}$ & 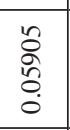 & $\begin{array}{l}\mathbf{r} \\
\hat{0} \\
0 \\
0 \\
0\end{array}$ & 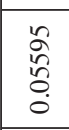 \\
\hline
\end{tabular}




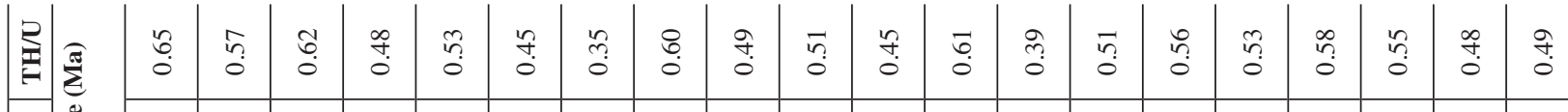

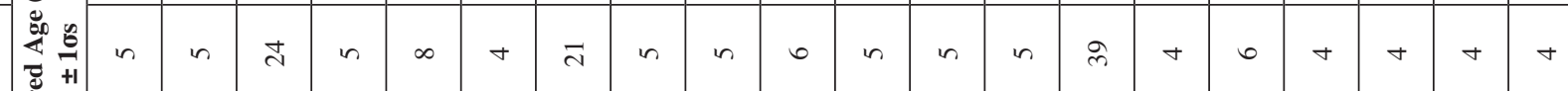

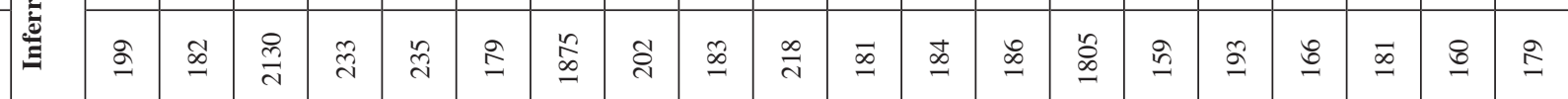
运

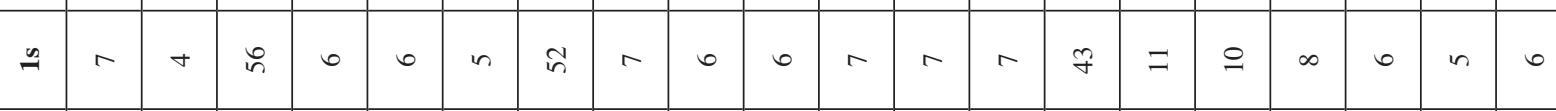

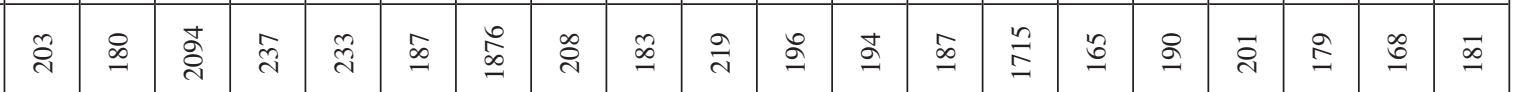

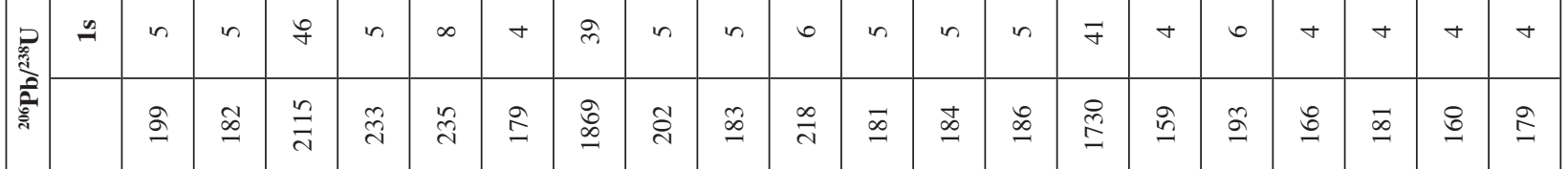

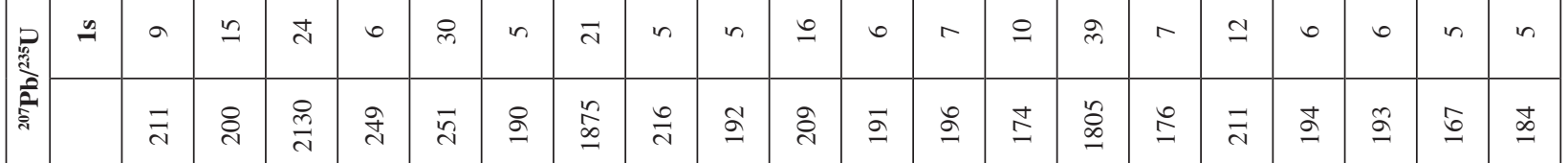

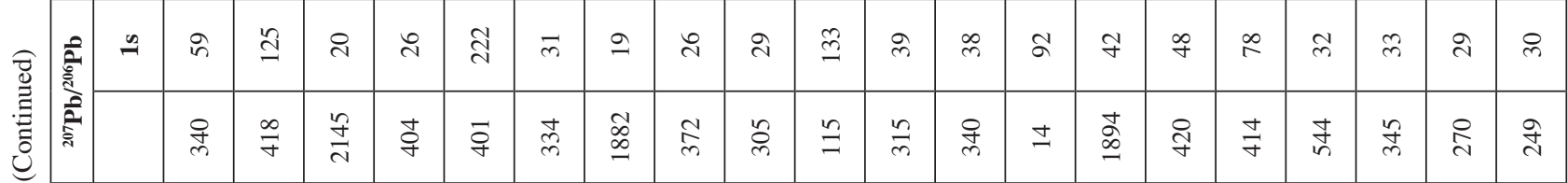

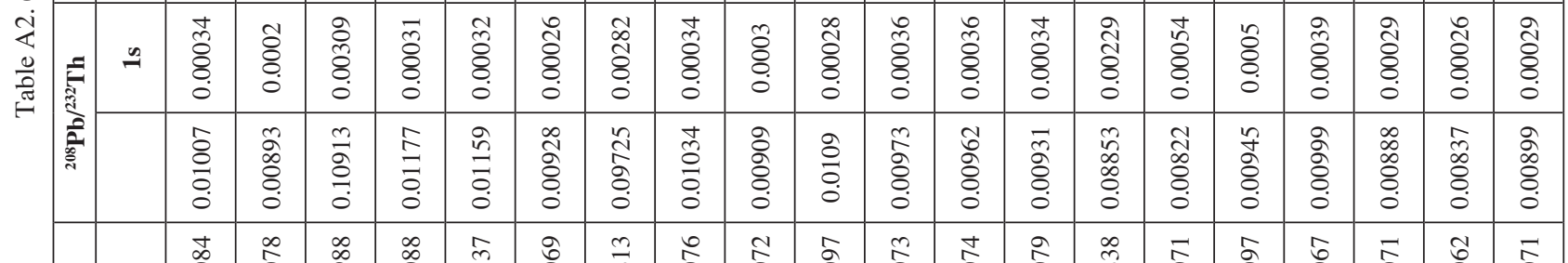

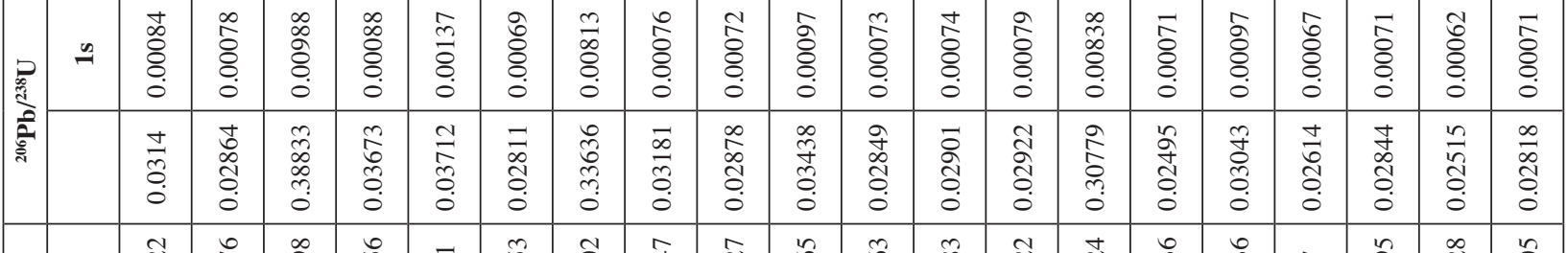

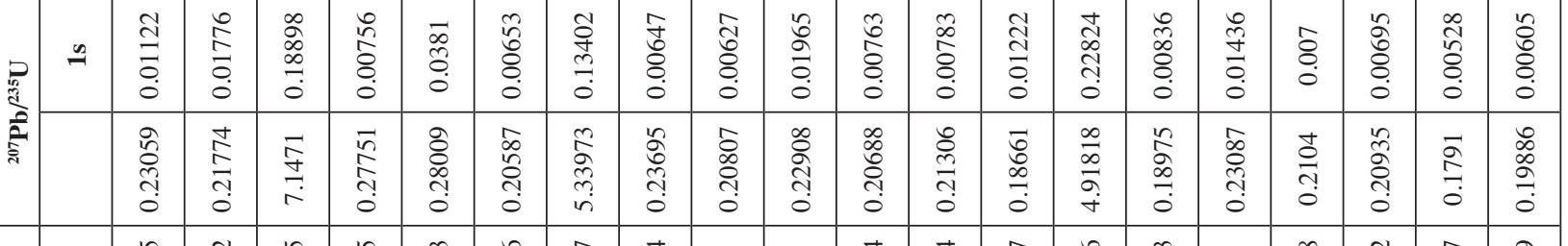

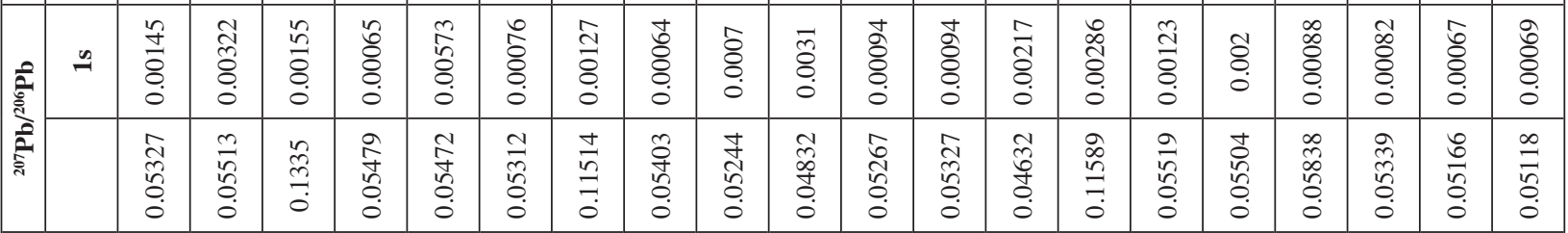

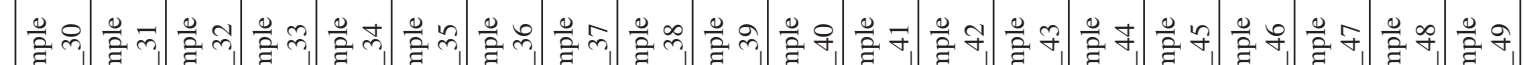

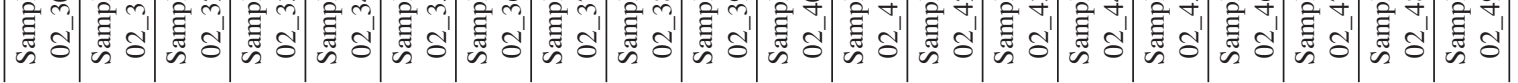




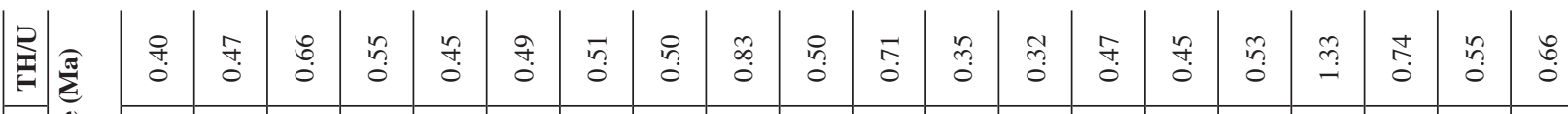

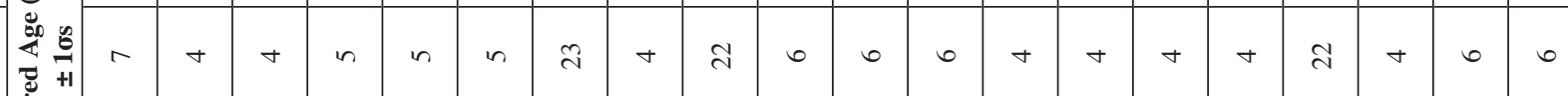

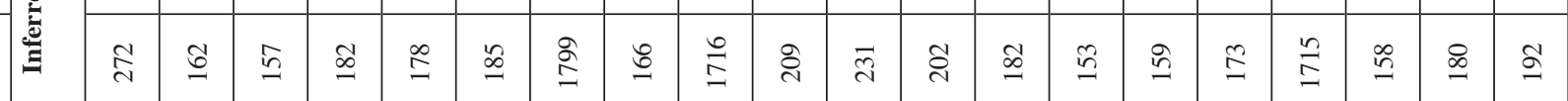

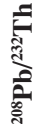
$\therefore$ a 5 in 0 J

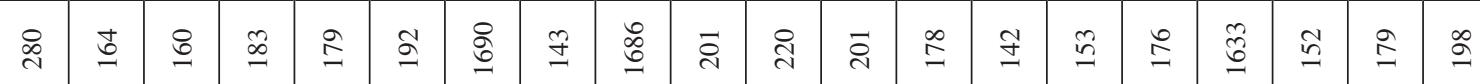

里

$2 \sim$

竞

ปิ

量

$\stackrel{n}{2}$

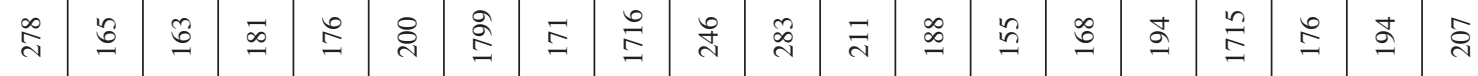



\begin{tabular}{|c|c|c|c|c|c|c|c|c|c|c|c|c|c|c|c|c|c|c|c|c|c|}
\hline \multirow{2}{*}{ 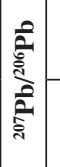 } & $\stackrel{9}{\Omega}$ & $\hat{\imath}$ & Әे & $\stackrel{\infty}{+}$ & 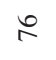 & a & $m$ & $\vec{v}$ & ch & $\stackrel{\text { ¿ }}{ }$ & in & $\bar{\lambda}$ & $\widehat{\underline{\varrho}}$ & ते & $\stackrel{\infty}{\sim}$ & $\stackrel{\infty}{\sim}$ & 专 & $\vec{N}$ & $\stackrel{m}{m}$ & $\widetilde{\alpha}$ & $?$ \\
\hline & & ల్ల & $\stackrel{\infty}{\sim}$ & $\sqrt[\hat{n}]{ }$ & $\stackrel{\infty}{\circ}$ & I & $\underset{ల}{\infty}$ & $\begin{array}{l}\infty \\
\infty \\
\infty\end{array}$ & ন & $\overrightarrow{\widetilde{\infty}}$ & ठ્రે & $\stackrel{\text { I }}{i}$ & $\stackrel{\sim}{m}$ & $\stackrel{\infty}{\stackrel{\sim}{\sim}}$ & $\stackrel{\infty}{\stackrel{\infty}{\sim}}$ & तે & $\stackrel{\infty}{\stackrel{\sim}{q}}$ & $n$ & $\begin{array}{l}\mathscr{\gamma} \\
\check{\gamma}\end{array}$ & $\stackrel{\circ}{n}$ & $\stackrel{\infty}{m}$ \\
\hline & 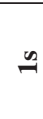 & 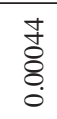 & 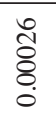 & 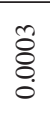 & 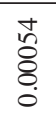 & 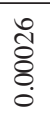 & 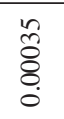 & 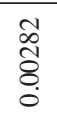 & 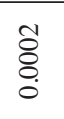 & 灾 & ठ̊. & 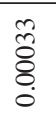 & 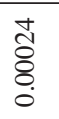 & 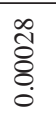 & $\ddot{0}$ & 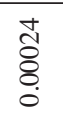 & 0 & 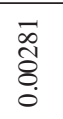 & $b$ & $\begin{array}{l}\text { ڤి } \\
\text { ઠ̊. } \\
\text {. }\end{array}$ & $\begin{array}{l}\square \\
8 \\
0\end{array}$ \\
\hline & & $\begin{array}{l}\tilde{m} \\
\stackrel{\tilde{m}}{\circ} \\
\dot{0}\end{array}$ & $\begin{array}{l}\frac{m}{0} \\
\stackrel{0}{0} \\
0 \\
0\end{array}$ & ڤั & $\begin{array}{l}\vec{\sigma} \\
\text { oे } \\
\dot{0}\end{array}$ & $\hat{\infty}$ & 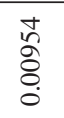 & 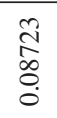 & ?ి & $\begin{array}{l}\vec{R} \\
\stackrel{0}{\infty} \\
0 \\
0\end{array}$ & $\hat{\circ}$ & $\begin{array}{l}\text { ò } \\
\text { o } \\
0 \\
0\end{array}$ & $\begin{array}{l}\text { ठे } \\
\text { ठे }\end{array}$ & $\begin{array}{l}\infty \\
\infty \\
\infty \\
0 \\
0 \\
0\end{array}$ & $\circ$ & $\infty$ & $\begin{array}{l}\text { n } \\
\infty \\
8\end{array}$ & & 6 & & $\begin{array}{l}\text { \& } \\
\stackrel{0}{0} \\
0 \\
0\end{array}$ \\
\hline \multirow[t]{2}{*}{$\infty$} & 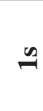 & $\frac{\tilde{o}}{0}$ & $\begin{array}{l}\text { ôे } \\
8 \\
0 \\
0\end{array}$ & 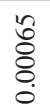 & $\begin{array}{l}\infty \\
\varnothing \\
0\end{array}$ & $\bar{\alpha}$ & $\stackrel{t}{\grave{E}}$ & $\begin{array}{l}\text { Oे } \\
\& \\
\stackrel{0}{0} \\
0\end{array}$ & d & 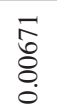 & $\ddot{c}$ & $\begin{array}{l}\bar{\sigma} \\
\text { oे } \\
\text { o. }\end{array}$ & $\stackrel{\infty}{\infty}$ & 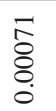 & 0 & 8 & 5 & & & & $\begin{array}{l}\text { ôे } \\
\text { ठ̊ } \\
\text {. }\end{array}$ \\
\hline & & $\begin{array}{l}\text { oे } \\
\text { +े } \\
\text {. }\end{array}$ & $\begin{array}{l}\hat{\tilde{n}} \\
\text { त̂. } \\
\text { o. }\end{array}$ & $\stackrel{0}{0}$ & 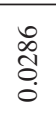 & $\ddot{d}$ & $\overline{\mathrm{A}}$ & $\begin{array}{l}\frac{m}{5} \\
\frac{n}{3} \\
0\end{array}$ & $\vec{\sigma}$ & 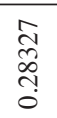 & $\overrightarrow{0}$ & $\begin{array}{l}\text { ad } \\
\text { d } \\
0\end{array}$ & $\stackrel{\circ}{\infty}$ & 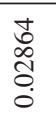 & $\&$ & 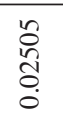 & $\underset{i}{\stackrel{i}{*}}$ & & 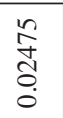 & & 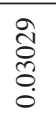 \\
\hline \multirow[t]{2}{*}{8} & $\stackrel{n}{\sim}$ & 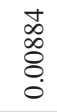 & 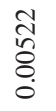 & $\stackrel{F}{I}$ & $\begin{array}{l}\stackrel{0}{1} \\
\\
0\end{array}$ & 0 & $\stackrel{\infty}{\stackrel{2}{\varrho}}$ & $\frac{\infty}{\stackrel{\infty}{m}} \stackrel{0}{0}$ & $\vec{J}$ & $\begin{array}{l}\stackrel{\infty}{\infty} \\
\stackrel{1}{=}\end{array}$ & $\tilde{d}$ & ลี & $\mathscr{b}_{0}^{\infty}$ & $\vec{\delta}$ & $r$ & $\tilde{n}$ & in & & $\stackrel{1}{5}$ & $=$ & $\begin{array}{l}\overrightarrow{\widehat{\hat{A}}} \\
\stackrel{0}{0} \\
\stackrel{0}{0}\end{array}$ \\
\hline & & $\frac{\infty}{\stackrel{o}{+}}$ & $\begin{array}{l}\text { ڤ్ } \\
\stackrel{0}{0} \\
0\end{array}$ & کु్ర & 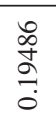 & $\begin{array}{l}\mathscr{b} \\
\infty \\
\infty\end{array}$ & $\frac{n}{\stackrel{n}{a}}$ & 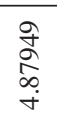 & $\vec{్}$ & 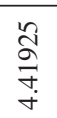 & $\stackrel{N}{\sim}$ & 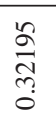 & 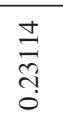 & $\begin{array}{l}\hat{\widehat{ิ}} \\
\text { ஸે }\end{array}$ & $\begin{array}{l}+ \\
\tilde{n} \\
0 \\
0 \\
0\end{array}$ & 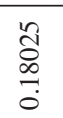 & 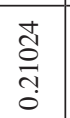 & $\vec{\infty}$ & $\begin{array}{l}\stackrel{n}{2} \\
\stackrel{0}{0} \\
\stackrel{0}{0}\end{array}$ & ডু & $\begin{array}{l}\text { ర్ర } \\
\text { ָ̦ } \\
0\end{array}$ \\
\hline & $\cong$ & $\begin{array}{l}n \\
\delta \\
\delta \\
0\end{array}$ & $\begin{array}{l}\text { : } \\
8 \\
8 \\
0\end{array}$ & $\stackrel{m}{8}$ & $\frac{b}{0}$ & J & $\begin{array}{l}\infty \\
\stackrel{8}{0} \\
\vdots \\
0\end{array}$ & $\frac{m}{m}$ & $\stackrel{\infty}{\varrho}$ & $\frac{\tilde{m}}{8}$ & $\stackrel{n}{\circ}$ & 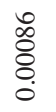 & $\begin{array}{l}\text { ते } \\
\text { ठे } \\
\text { के }\end{array}$ & $\begin{array}{l}\hat{8} \\
8 \\
0 \\
0\end{array}$ & $\begin{array}{l}\text { O̊̊ } \\
8 \\
0 \\
0\end{array}$ & $\begin{array}{l}\infty \\
\stackrel{\circ}{0} \\
\vdots \\
0\end{array}$ & $\stackrel{\Xi}{\overline{8}}$ & $\begin{array}{l}\stackrel{+}{\mathrm{I}} \\
\stackrel{\Xi}{8}\end{array}$ & $\begin{array}{l}\text { ô } \\
\text { ठे } \\
\text {. }\end{array}$ & $\begin{array}{l}0 \\
0 \\
0 \\
0 \\
0\end{array}$ & $\begin{array}{l}\frac{0}{2} \\
\stackrel{8}{8} \\
0\end{array}$ \\
\hline & & $\begin{array}{l}\tilde{\delta} \\
\tilde{\delta} \\
\delta \\
0\end{array}$ & $\begin{array}{l}n \\
0 \\
0 \\
0 \\
0\end{array}$ & ల] & $\begin{array}{l}\frac{O}{+} \\
\dot{\sigma} \\
\dot{O} \\
\dot{0}\end{array}$ & $\hat{\infty}$ & $\begin{array}{l}\vec{y} \\
y \\
0 \\
0 \\
0\end{array}$ & 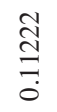 & $\bar{n}$ & $\begin{array}{l}\frac{n}{n} \\
= \\
0\end{array}$ & $\begin{array}{l}\text { J } \\
\stackrel{8}{0} \\
0 \\
0\end{array}$ & $\begin{array}{l}\vec{f} \\
\stackrel{d}{0} \\
\stackrel{0}{0}\end{array}$ & $\begin{array}{l}\text { U. } \\
\widetilde{1} \\
0 \\
0\end{array}$ & $\begin{array}{l}0 \\
\frac{1}{2} \\
\stackrel{0}{0}\end{array}$ & \begin{tabular}{l}
$n$ \\
$\infty$ \\
\multirow{O}{0}{} \\
0 \\
0
\end{tabular} & $\stackrel{\vec{n}}{\circ}$ & 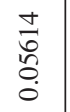 & $\bar{\sigma}$ & $\begin{array}{l}0 \\
\stackrel{0}{0} \\
0 \\
0 \\
0\end{array}$ & $\stackrel{\substack{n \\
\tilde{n}}}{n}$ & 疍 \\
\hline & & & & & & & & & & & & & & & & & & & & & \\
\hline
\end{tabular}


司|

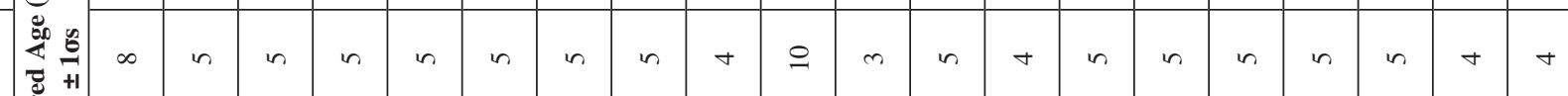

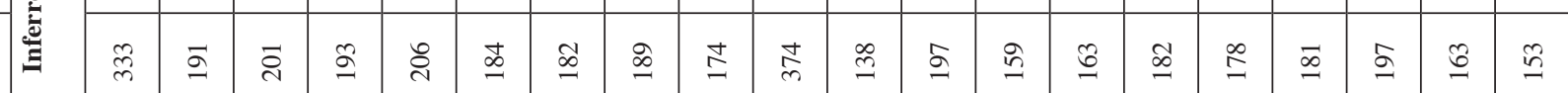
产

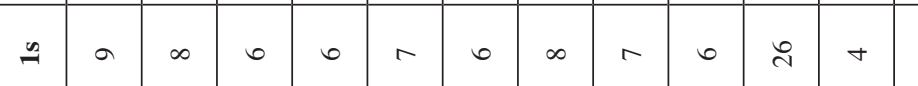

察

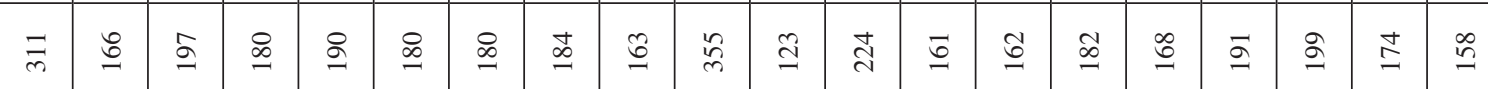

敢 $\because \infty \quad n \quad n \quad n \quad n \quad n \quad n \quad n \quad+\quad$ i

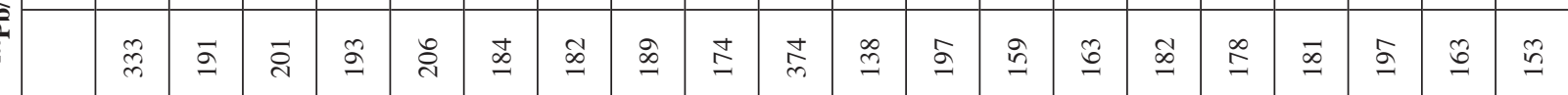
疍

\begin{tabular}{|c|c|c|c|c|c|c|c|c|c|c|c|c|c|c|c|c|c|c|c|}
\hline$\infty$ & $a$ & 0 & $r$ & $r$ & 0 & $r$ & $r$ & in & \pm & $\nabla$ & 0 & $n$ & $\exists$ & 0 & 0 & $\infty$ & $n$ & $n$ & $\forall$ \\
\hline$\hat{m}$ & $\stackrel{\vec{\nu}}{\vec{v}}$ & 워 & $\stackrel{\sim}{\sim}$ & & $\stackrel{2}{\circ}$ & $\mathscr{\infty}$ & $\bar{\sigma}$ & $\stackrel{\text { }}{2}$ & ๙ૂ & g & 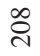 & $\stackrel{\infty}{\simeq}$ & $\Xi$ & 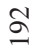 & $\stackrel{\infty}{\varnothing}$ & $\stackrel{\infty}{\infty}$ & $\underset{\sim}{~}$ & $\stackrel{尺}{ }$ & $\stackrel{\infty}{n}$ \\
\hline
\end{tabular}

\begin{tabular}{|c|c|c|c|c|c|c|c|c|c|c|c|c|c|c|c|c|c|c|c|c|}
\hline \multirow[b]{2}{*}{5} & $\approx$ & ㄴ & ก & নे & ले & $m$ & $n$ & $\stackrel{m}{\forall}$ & 壮 & $m$ & \& & $\hat{\lambda}$ & $m$ & $\stackrel{\infty}{\sim}$ & $\stackrel{\circ}{\circ}$ & ల & 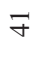 & ก & $\hat{\lambda}$ & nै \\
\hline & & ల్ల & 丘 & ర్ల & $\stackrel{\infty}{\vartheta}$ & ஓ্ল & : & స్ & $\bar{\sim}$ & $\widehat{\beth}$ & $\stackrel{\infty}{\circ}$ & ల్ల & 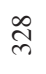 & $\stackrel{f}{f}$ & $\stackrel{\leftrightarrow}{\infty}$ & $\frac{m}{m}$ & 유 & $\stackrel{\curvearrowright}{\hat{~}}$ & $\underset{d}{\vec{J}}$ & $\stackrel{\text { D }}{~}$ \\
\hline
\end{tabular}
茪

\begin{tabular}{|c|c|c|c|c|c|c|c|c|c|c|c|c|c|c|c|c|c|c|c|c|}
\hline$\approx$ & 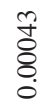 & $\begin{array}{l}\text { ¿̊. } \\
8 \\
0\end{array}$ & 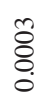 & $\begin{array}{l}\overrightarrow{0} \\
\delta \\
8 \\
0\end{array}$ & $\begin{array}{l}\mathscr{8} \\
\delta \\
\delta\end{array}$ & 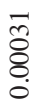 & $\begin{array}{l}\vec{\nabla} \\
8 \\
8 \\
\vdots\end{array}$ & $\begin{array}{l}n \\
\tilde{\delta} \\
\delta \\
0\end{array}$ & 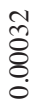 & $\begin{array}{l}m \\
\stackrel{2}{8} \\
\stackrel{0}{0}\end{array}$ & $\begin{array}{l}\frac{\infty}{8} \\
8 \\
0\end{array}$ & 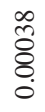 & 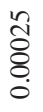 & 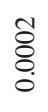 & $\begin{array}{l}\vec{\delta} \\
\delta \\
\stackrel{8}{0}\end{array}$ & ஜ̊̊ & \begin{tabular}{l}
$\infty$ \\
$\stackrel{\infty}{8}$ \\
$\delta$ \\
\hdashline \\
\hdashline
\end{tabular} & 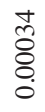 & 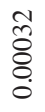 & ঠे \\
\hline & $\begin{array}{l}\stackrel{a}{0} \\
\stackrel{5}{0} \\
0\end{array}$ & $\begin{array}{l}0 \\
\stackrel{1}{0} \\
8 \\
0 \\
0\end{array}$ & $\begin{array}{l}\stackrel{2}{\sigma} \\
\dot{8} \\
\dot{0}\end{array}$ & 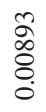 & $\begin{array}{l}\stackrel{n}{8} \\
8 \\
8 \\
\stackrel{8}{0}\end{array}$ & $\begin{array}{l}\stackrel{1}{2} \\
\infty \\
8 \\
0\end{array}$ & $\begin{array}{l}\Re \\
\infty \\
\delta \\
\stackrel{0}{0}\end{array}$ & $\begin{array}{l}\frac{n}{\sigma} \\
\frac{\delta}{0} \\
0\end{array}$ & $\begin{array}{l}\stackrel{2}{0} \\
\stackrel{8}{8} \\
\stackrel{0}{0}\end{array}$ & 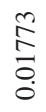 & $\begin{array}{l}8 \\
8 \\
8 \\
8 \\
0\end{array}$ & $\begin{array}{l}\stackrel{n}{\Xi} \\
\sigma o \\
0\end{array}$ & $\begin{array}{l}\infty \\
\stackrel{8}{8} \\
\stackrel{0}{0}\end{array}$ & $\begin{array}{l}+ \\
8 \\
8 \\
0\end{array}$ & $\begin{array}{l}\hat{8} \\
8 \\
8 \\
\circ\end{array}$ & $\begin{array}{l}\hat{\infty} \\
\infty \\
8 \\
0 \\
0\end{array}$ & $\begin{array}{l}\mathfrak{n} \\
\stackrel{8}{0} \\
0\end{array}$ & $\begin{array}{l}\hat{\infty} \\
\stackrel{8}{\delta} \\
0\end{array}$ & \begin{tabular}{l}
$\mathscr{8}$ \\
$\infty$ \\
8 \\
\hdashline
\end{tabular} & 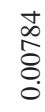 \\
\hline & ก & $\infty$ & $\infty$ & $\infty$ & $\infty$ & \pm & $\curvearrowright$ & $\stackrel{\infty}{\curvearrowright}$ & o & $\nabla$ & 䓃 & $\curvearrowright$ & $\hat{6}$ & $\mathfrak{N}$ & \pm & \pm & $\Sigma$ & $\Sigma$ & $n$ & \\
\hline
\end{tabular}

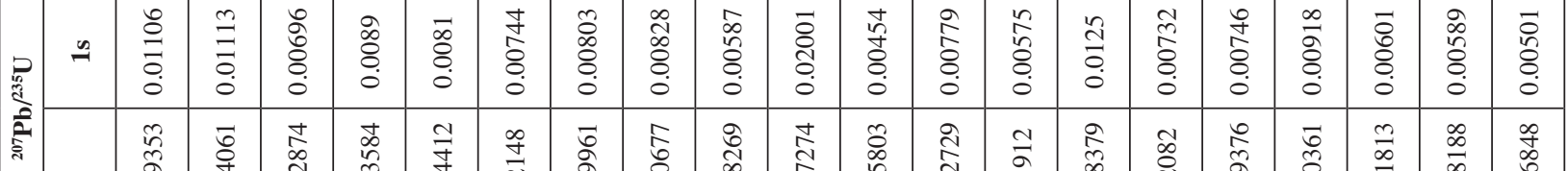

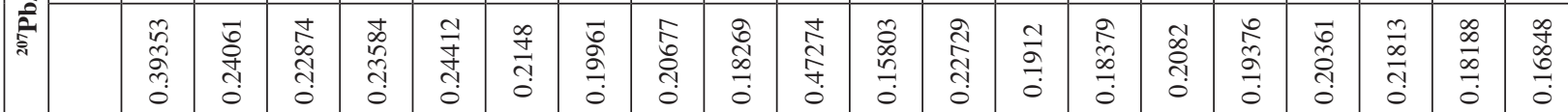

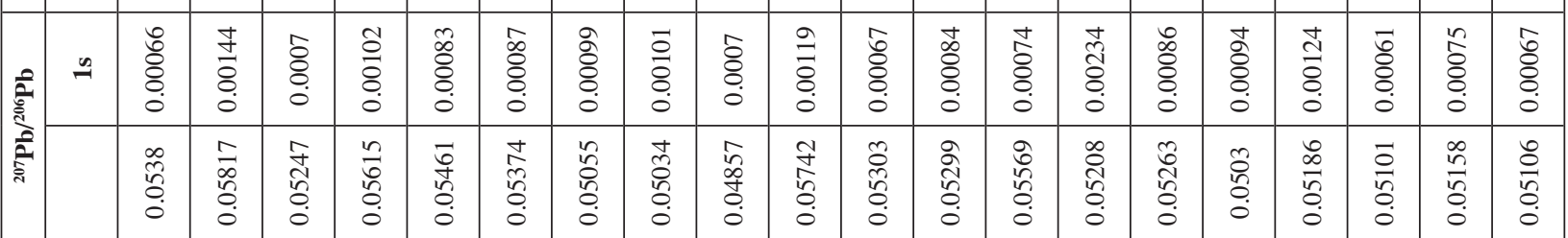

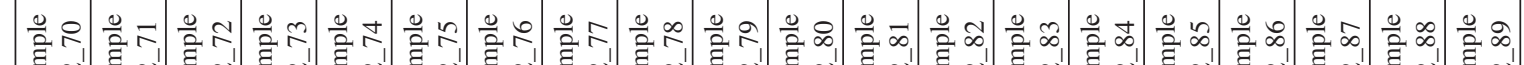

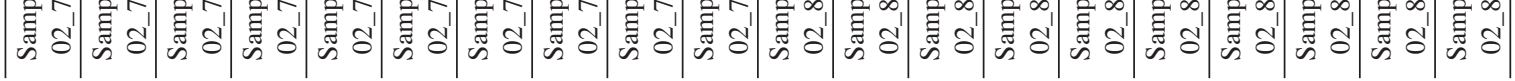




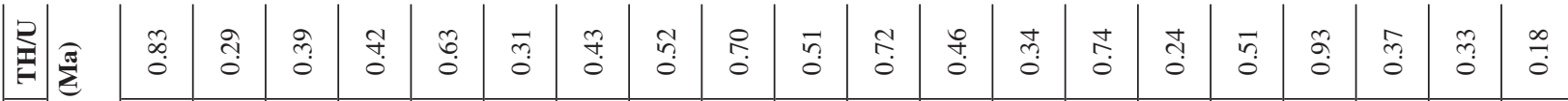

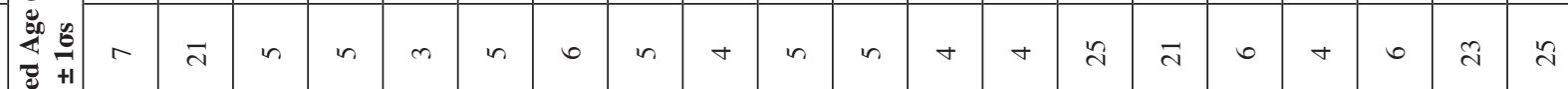
离 竞

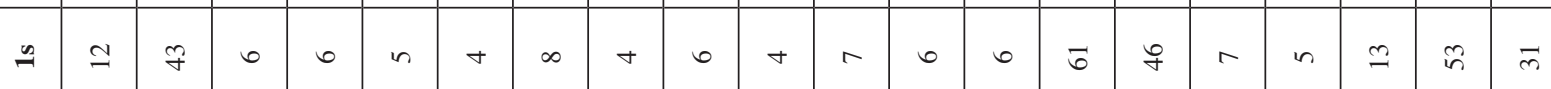
离 总

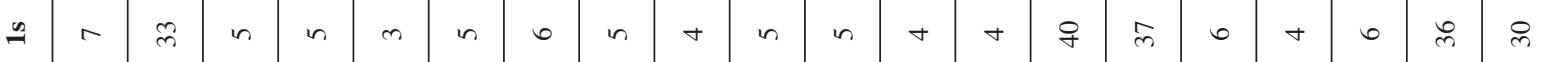
言

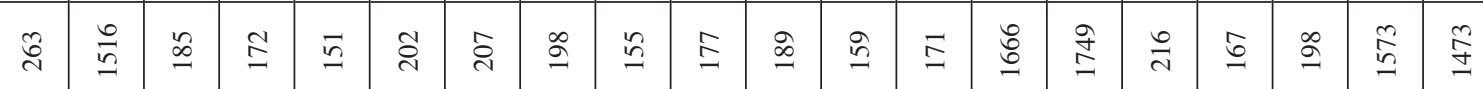
要

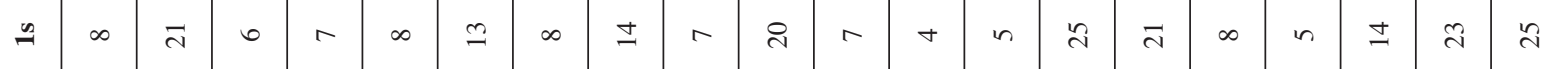
高

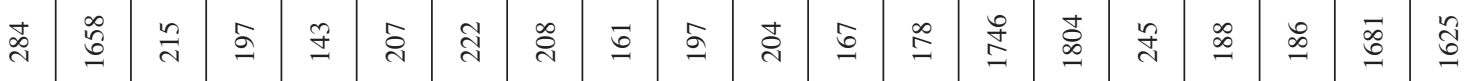

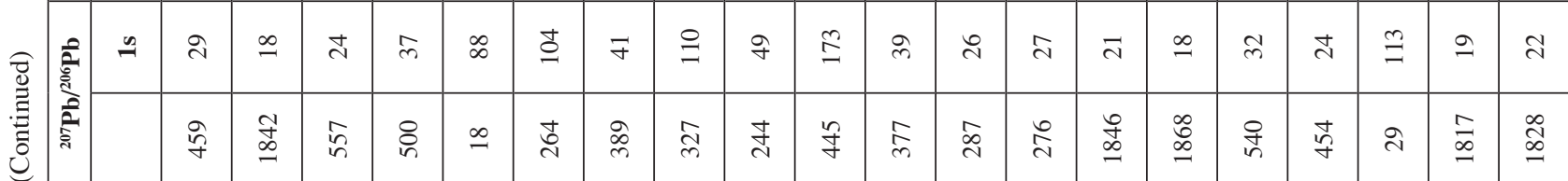
ז 要 吾

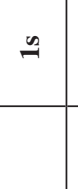

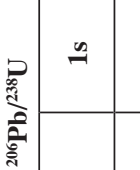

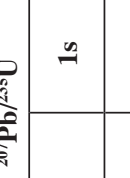

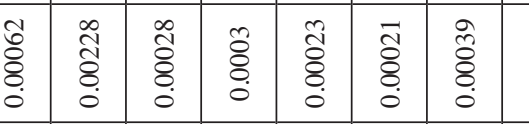

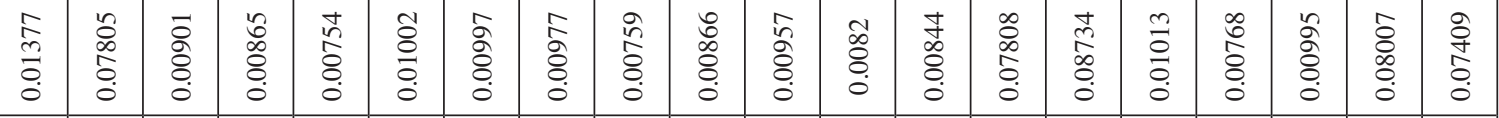

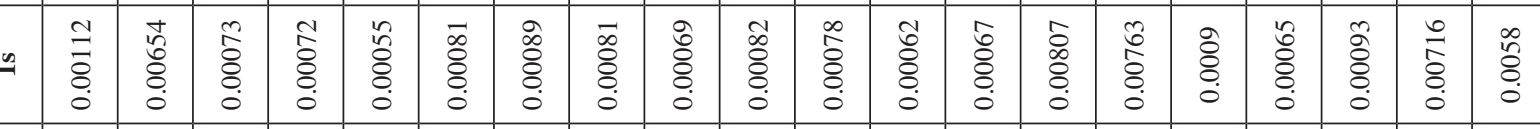

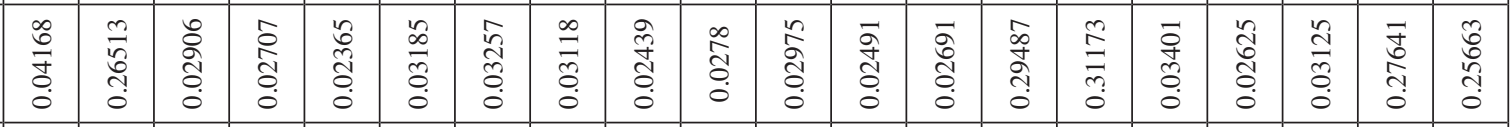

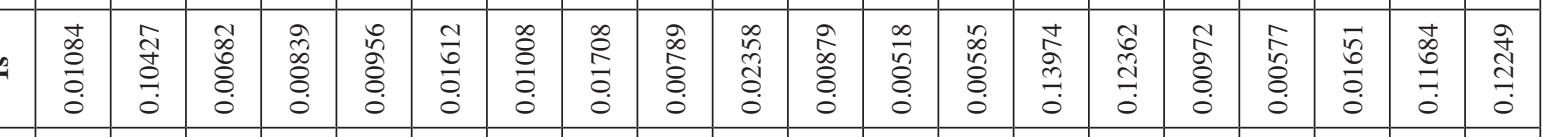

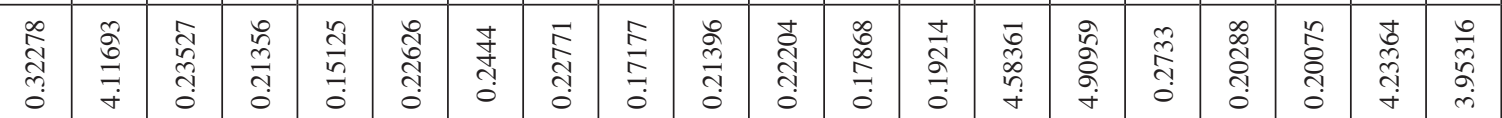

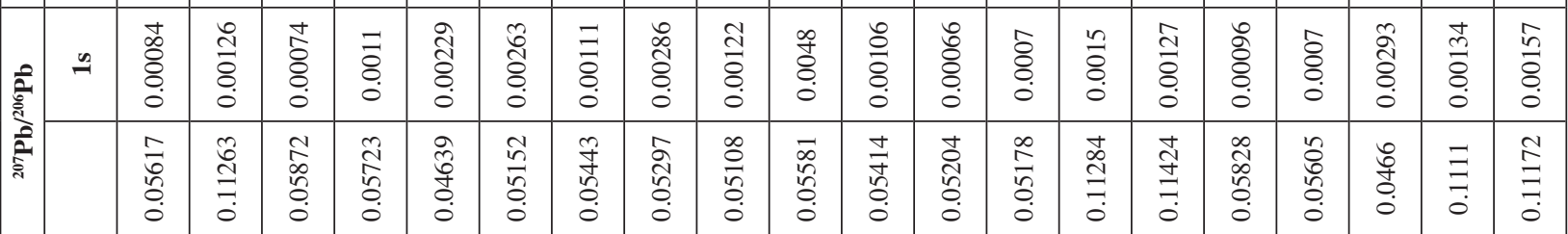

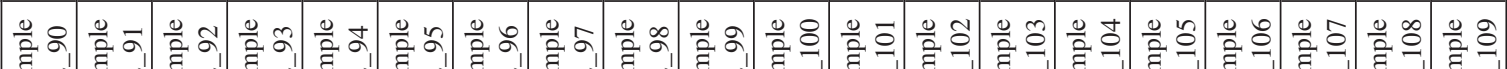

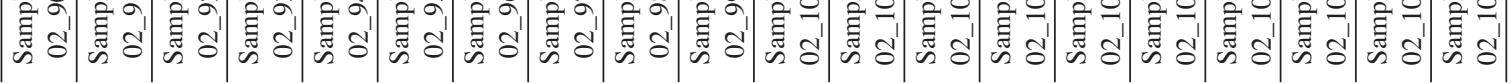




\begin{tabular}{|c|c|c|c|c|c|}
\hline \multirow[t]{2}{*}{ 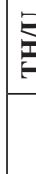 } & \multirow{2}{*}{ 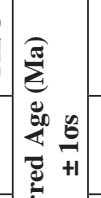 } & $\begin{array}{l}\infty \\
\tilde{c} \\
0\end{array}$ & $\stackrel{q}{g}$ & $\begin{array}{l}\infty \\
\stackrel{0}{0} \\
0\end{array}$ & $\begin{array}{l}\infty \\
\stackrel{0}{0} \\
0\end{array}$ \\
\hline & & in & in & $\nabla$ & 6 \\
\hline \multirow{3}{*}{ 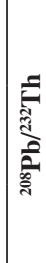 } & 岕 & 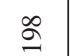 & $\stackrel{\infty}{\infty}$ & $\tilde{\bumpeq}$ & స్ \\
\hline & $\cong$ & $\infty$ & $r$ & $r$ & $a$ \\
\hline & & ڤે & $\Omega$ & $\stackrel{g}{\Xi}$ & స్తి \\
\hline \multirow{2}{*}{ 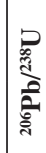 } & $\cong$ & in & in & $\nabla$ & 0 \\
\hline & & $\stackrel{\infty}{\approx}$ & $\stackrel{\infty}{\infty}$ & $\tilde{\Omega}$ & సి \\
\hline \multirow{2}{*}{ 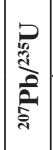 } & $\cong$ & 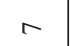 & 6 & 6 & 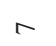 \\
\hline & & సે & ષ્సి & $\stackrel{\bullet}{\mathscr{C}}$ & 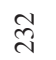 \\
\hline \multirow{2}{*}{ 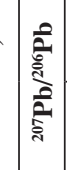 } & $\simeq$ & $m$ & $\hat{\lambda}$ & से & $m$ \\
\hline & & $\begin{array}{l}\infty \\
n \\
n\end{array}$ & 萂 & $\bar{ల}$ & $\vec{D}$ \\
\hline \multirow{2}{*}{ 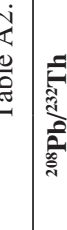 } & $\simeq$ & 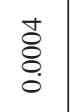 & $\begin{array}{l}+ \\
\text { ô } \\
8 \\
0\end{array}$ & $\begin{array}{l}n \\
\tilde{\delta} \\
\delta \\
0\end{array}$ & 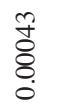 \\
\hline & & $\begin{array}{l}\tilde{a} \\
\vdots \\
0 \\
0 \\
0\end{array}$ & 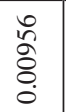 & $\begin{array}{l} \\
0 \\
0 \\
8 \\
0 \\
0\end{array}$ & 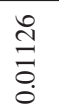 \\
\hline \multirow{2}{*}{ 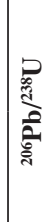 } & $\simeq$ & $\begin{array}{l}\hat{\hat{s}} \\
\delta \\
0 \\
0\end{array}$ & $\begin{array}{l}n \\
\hat{8} \\
8 \\
0\end{array}$ & $\begin{array}{l}8 \\
8 \\
8 \\
0\end{array}$ & $\begin{array}{l}\text { ठे. } \\
\text { ठ. } \\
\text {. }\end{array}$ \\
\hline & & $\begin{array}{l}\tilde{a} \\
\tilde{\sigma} \\
0 \\
0\end{array}$ & 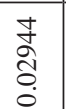 & $\begin{array}{l}\infty \\
\infty \\
0 \\
\tilde{\delta} \\
0 \\
0\end{array}$ & 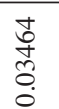 \\
\hline \multirow{2}{*}{ 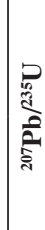 } & 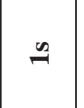 & $\begin{array}{l}\tilde{\delta} \\
\delta \\
8 \\
0 \\
0\end{array}$ & 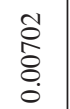 & $\begin{array}{l}\tilde{n} \\
\delta \\
0 \\
0\end{array}$ & 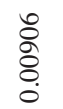 \\
\hline & & 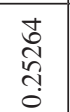 & \begin{tabular}{l}
+ \\
\multirow{2}{n}{} \\
ปे \\
0
\end{tabular} & 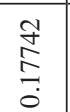 & $\begin{array}{l}n \\
\stackrel{n}{0} \\
\text { તે̣ } \\
0\end{array}$ \\
\hline \multirow{2}{*}{ 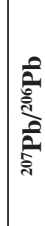 } & $\simeq$ & $\overrightarrow{8}$ & 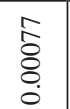 & 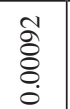 & $\begin{array}{l}l \\
\infty \\
o \\
0 \\
0\end{array}$ \\
\hline & & $\begin{array}{l}+ \\
D \\
\infty \\
0 \\
0 \\
0\end{array}$ & 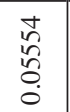 & $\begin{array}{l}\hat{\hat{R}} \\
\hat{0} \\
0 \\
0\end{array}$ & $\begin{array}{l}\hat{n} \\
\hat{n} \\
\tilde{o} \\
0\end{array}$ \\
\hline & & 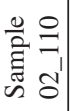 & $\Xi_{1}$ & 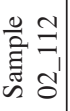 & 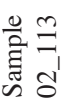 \\
\hline
\end{tabular}

